\title{
ASPECTOS GENÉTICOS DA FIXAÇÃO ASSIMBIÓTICA DE NITROGÊNIO EM BACTÉRIAS DO SOLO
}

\author{
GISLENE GARCIA FRANCO DO NASCIMENTO
}

Orientador: FLÁVIO CESAR ALMEIDA TAVARES

Tese apresentada à Escola Superior de Agricultura "Luiz de Queiroz", da Universidade de São Paulo, para obtenção do título de Doutor em Agronomia. Área de Concentração: Genética $\theta \mathrm{Me-}$ Ihoramento de Plantas.

PIRACICABA

Estado de São Paulo - Brasil

Setembro - 1985 
$-i-$

Ao meu esposo

virgizio

e aos meus filhos

Mauricio e Alexandre 


\section{AGRADECIMENTOS}

- Ao Prof. Dr. Flávio Cesar Almeida Tavares pela confiança e orientação recebida.

- Ao colega Sergio Echeverrigaray Laguna pela amizade e sugestões durante a realização do trabalho.

- Ao Departamento de Genética que possibilitou a participa ção no curso de pós-graduação e realizaçãodeste trabalho.

- Ao Dr. Diógenes S. Santos e Dr. Caio Cardoso pela doação de amostras bacterianas.

- A Dra. Maria HeZoisa Affonso pelas sugestões na elaboração, de análises eletroforéticas.

- A Dra. Siu Mui Tsai Saito pela colaboração nas anälises de redução de acetileno.

- A CAPES pela bolsa concedida e à FINEP pelos recursos con cedidos para a realização deste trabalho.

- Aos técnicos de Zaboratório do Setor de Genética de Microrganismos. 
$\underline{\text { Pàgina }}$

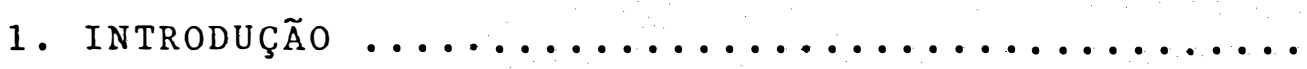

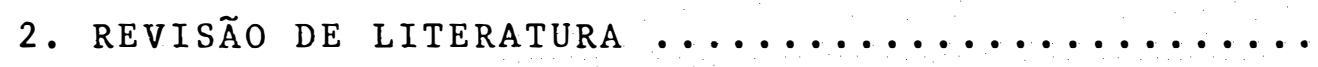

2.1. Considerações gerais sobre a fixação de nitrogênio em organismos de vida livre ......

2.2. Aspectos genéticos da fixação de nitrogênio

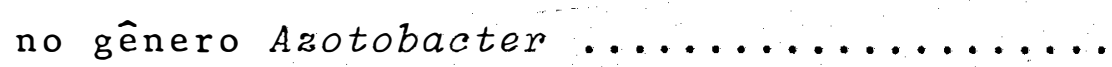

2.3. Ocorrência de plasmídios em bactérias fixa-

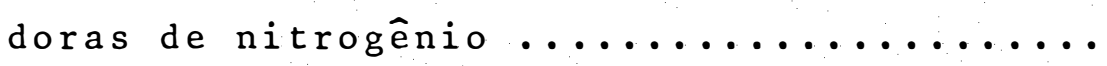

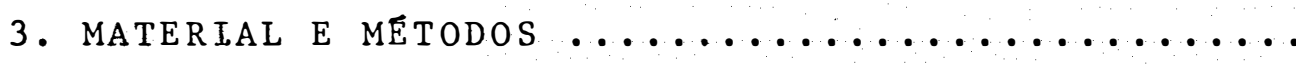

3.1. Amostras bacterianas utilizadas ........... 35

3.2. Meios de cultura e soluções ............ 38

3.3. Isolamento de bactérias assimbióticas do so

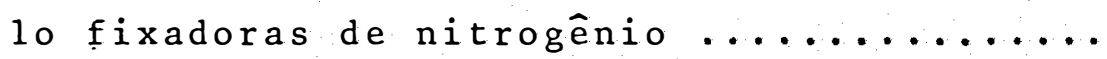

3.4. Verificação da ocorrência de plasmídios das bactérias fixadoras de nitrogênio ........

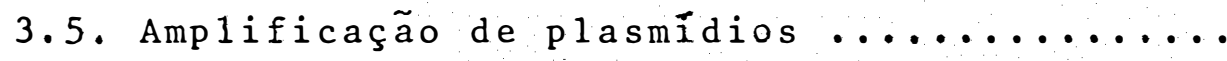

3.6. Estimativa dos pesos moleculares dos plasmí dios de linhagens fixadoras de $\mathrm{N}_{2} \ldots \ldots \ldots$

3.7. Eliminação de plasmídios das linhagens fixa

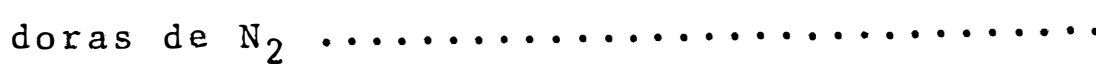




\section{$\underline{\text { Pàgina }}$}

3.8. Identificação taxonômica do isolado bacte-

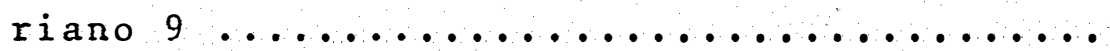

3.9. Determinação do nível de resistência do iso

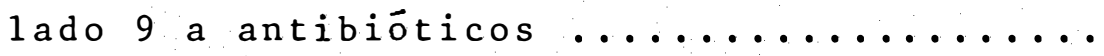

3.10. Curva de sobrevivência do isolado 9 à radia

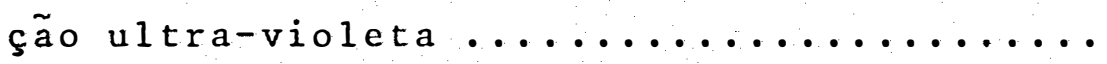

3.11.Curva de sobrevivência do isolado 9 a trata

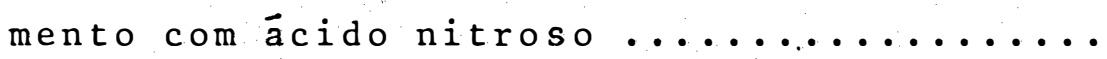

3.12.0btenção de mutantes $n i f^{-}$no isolado 9 atra vés da irradiação com luz ultra-violeta e

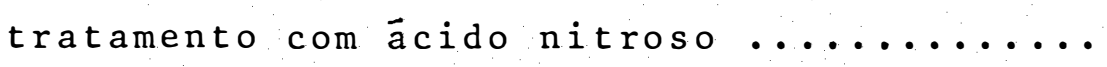

3.13. Auxanografia dos mutantes $n i f^{-} \ldots \ldots \ldots \ldots$

3.14. Isolamento de mutantes resistentes a anti bioticos $\ldots \ldots \ldots \ldots \ldots \ldots \ldots \ldots \ldots \ldots \ldots \ldots \ldots \ldots \ldots \ldots \ldots \ldots \ldots$

3.15. Extração de DNA total do isolado 9 e mutan

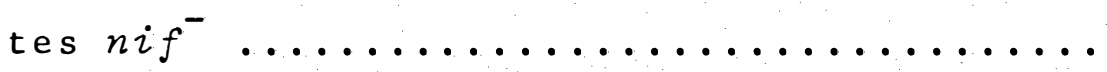

3.16. Experimentos de transformação utilizando o DNA do isolado 9 e dos mutantes $n i f^{-} \ldots \ldots . . .58$

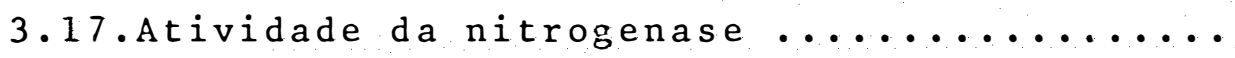

3.18. Comparação do crescimento entre transforman tes $n i f^{t}$ de $E$. coli e isolado $9 \ldots \ldots \ldots$

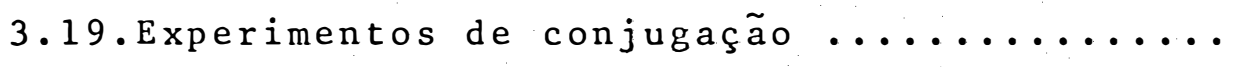

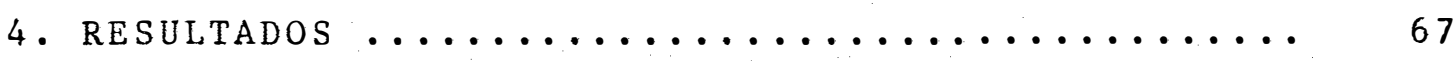

4.1. Isolamento de bactérias fixadoras de $\mathrm{N}_{2} \ldots \ldots$ 
$\underline{\text { Pàgina }}$

4.2. Ocorrência de plasmídios em bactérias fixadoras de $\mathrm{N}_{2} \ldots \ldots \ldots \ldots \ldots \ldots \ldots \ldots \ldots \ldots \ldots \ldots \ldots \ldots \ldots \ldots \ldots \ldots \ldots \ldots$

4.3. Eliminação de plasmídios em linhagens fi-

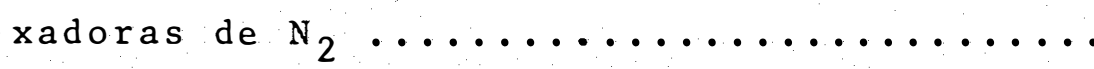

4.4. Níve1 de resistência a drogas no isolado $9 .$.

4.5. Curva de sobrevivência e obtenção de mutantes $n i f^{-}$à irradiação ultra-violeta e trata

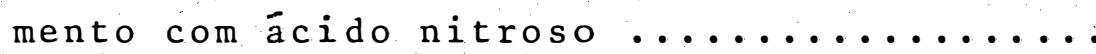

4.6. Experimentos de transformação ............

4.7. Atividade da nitrogenase e crescimento dos

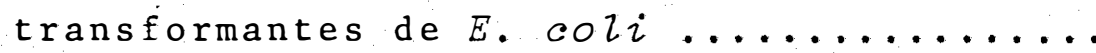

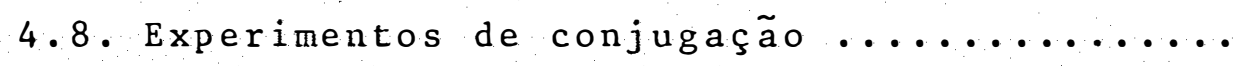

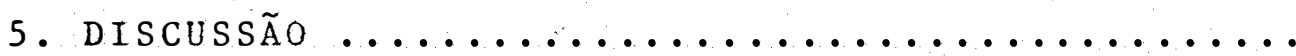

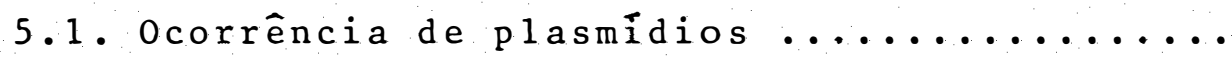

5.2. Estudos genéticos no isolado 9 (Azotobacter

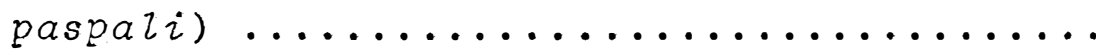

6. conclusões $\ldots \ldots \ldots \ldots \ldots \ldots \ldots \ldots \ldots \ldots \ldots \ldots \ldots \ldots \ldots \ldots \ldots \ldots$

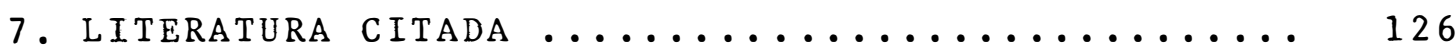




\section{LISTA DE TABELAS}

Tabe 1 a

Pägina

1 Características e procedências das Iinha gens bacterianas utilizadas neste traba-

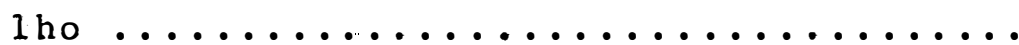

2 - Porcentagem de éliminação de plasmídios através do tratamento com agentés de "cuㅡ ra" em 1 inhagens fixadoras de $\mathrm{N}_{2} \ldots \ldots$

3 Nível de resistência do isolado 9 a anti

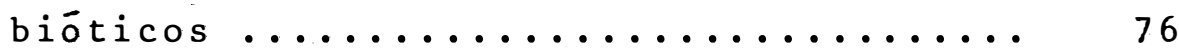

4 Sobrevivência do isolado 9 à irradiação

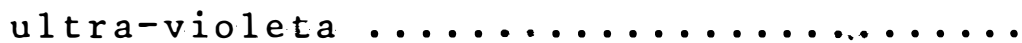

5 Sobrevivência do isolado 9 ao tratamento com ācidonitroso $\ldots \ldots \ldots \ldots \ldots \ldots \ldots \ldots$

6 - Porcentagem de recombinantes $n i f^{+}$datrans formação entre mutantes $n i f^{-}$e DNA do i-

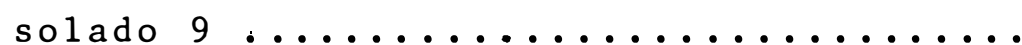

7 - Porcentagem de transformantes nif $f^{+}$obtidos de cruzamentos entre mutantes $n i f^{-}$e

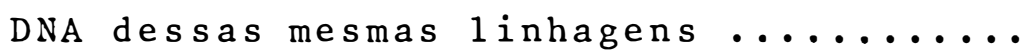

8 - Transformação de 1 inhagens de $E$. coli e levedura $S$. cerevisiae com DNA do isolado 9

9 - Atividade da nitrogenase nos transformantes de $E$. coli e isolado 9 medida pela

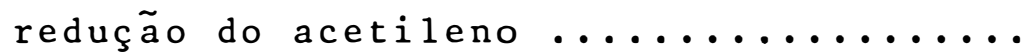


10 Crescimento dos transformantes $n i f^{+}$e 1 i nhagem HBI01 de E. coli e isolado 9 em meio com nitrogênio incorporado ........

11 - Crescimento dos transformantes $n i f^{+}$e 1 i nhagem HBI01 de E. coli e isolado 9 em meio sem nitrogênio incorporado .......

12 - Porcentagem de conjugação entre transfor mantes 101 (9) e 1 inhagens de E. colipor-

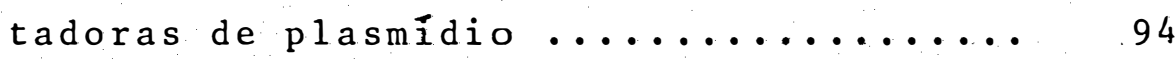

13 - Conjugação entre transformantes $n i f^{+}$de

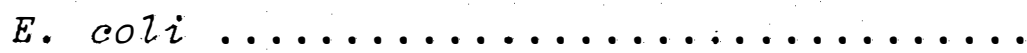

14 Porcentagem de recombinantes na conjugação entre E. coli portadora de plasmídio com transposon e 1 inhagens $101(9) 1$ e 9 .. 


\section{LISTA DE FIGURAS}

$\underline{\text { Figura }}$

$\underline{\text { Pàgina }}$

1 Modelo simplificado para o controle posi tivo da nitrogenase em $A$. vinelandii...

2 Eletroforese em gel de agarose de isola dos bacterianos fixadores assimbióticos

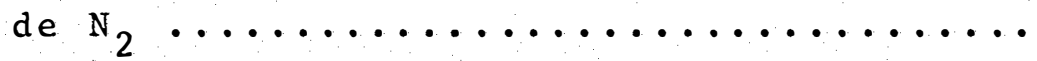

3 - Reta de calibração para estimativa dos pesos moleculares de plasmídios a partir

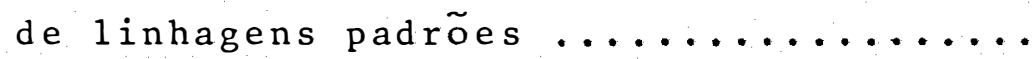

4 - Cultura de 2 e 4 dias do isolado 9 , em meio sem nitrogênio incorporado ........

5 - Cultura de 7 e 10 dias do isolado 9, em meio sem nitrogênio incorporado .......

6 - Curva de sobrevivência do isolado 9 à irradiação ultra-violeta e tratamento com

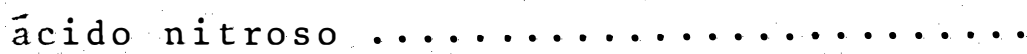

7 - Ordem das mutações afetando a fixação

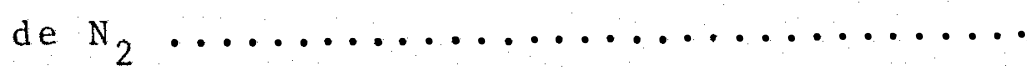

8 - Curvas de crescimento dos transformantes, linhagem HBI01 de $E$. coli e isolado 9 em meio com nitrogênio incorporado ....... Curvas de crescimento dos transformantes de E. coli e isolado 9 em melo sem 
10 - Cultura de três dias das linhagens HB101, 9 e transformantes $101(9) 2$ em meio com e

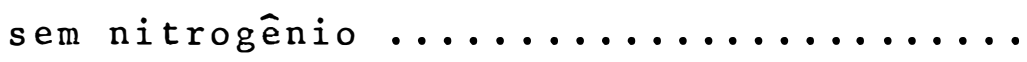




\section{ASPECTOS GENETICOS DA FIXAÇÃO ASSIMBIÓTICA}

DE NITROGENIO EM BACTERIAS DO SOLO

Gislene Garcia Franco do Nascimento

Flávio Cesar Almeida Tavares

orientador

\section{RESUMO}

Foi feito um estudo dos genes envolvidos com o processo de fixação assimbiótica de $\mathrm{N}_{2}$, em populaçóes bac terianas selvagens do solo, com o intuito de se verificar a ocorrência de genes nif plasmidiais, ou mesmo cromossomais, que pudessem ser transferidos para outros sistemas não fixadores. Foi observada a presença de plasmídios nos isolados naturais 2-2II, 5-3 e 40-1 com pesos moleculares de 64, 40 e 92 Md, respectivamente, revelados por eletroforese em gel de agarose. Em nenhuma destas linhagens se detectou a presença de genes plasmidiais envolvidos com o processo de fixação de $\mathrm{N}_{2}$, uma vez que após a eliminação dos plasmídios com agentes de "cura", estas continuaram seu desenvolvimento normal em meio isento de nitrogênio incorporado. A maior 
porcentagem de eliminação de plasmídios foi conseguida atra vés do tratamento com temperatura de $44^{\circ} \mathrm{C}(2$ a $10 \%)$, seguida do tratamento com brometo de etídio $(1$ a $5 \%)$, sendo meno res as obtidas com acriflavina $(0,5$ a $1 \%)$ e acridina 1 aranja $(0,2$ a $0,8 \%)$. Pode-se verificar que a presença, assim como o tamanho dos plasmídios presentes, nãofoi uma constante,pois variaram coma espécie, mostrando a grande variabilidade gene tica deste material. 0 isolado selvagem 9, não portador de plasmídio, classificado como Azotobacter paspali, foi estudado sob vários aspectos genéticos. Teve-se como objetivo, a localização dos genes nif nesta bactéria, procurando-se ainda uma similaridade com outras espécies do mesmo gênero, bem estudadas geneticamente. Neste sentido, inicialmente foram isolados alguns mutantes auxotróficos e nif (incapazes de fixar $\mathrm{N}_{2}$ ), a partir da indução com luz ultra-violeta e tratamento com äcido nitroso. A localização de algumas mutações nif foi possível através da transformação destes mutantes $n i f^{-}$com DNA de $A$. paspali selvagem e mutante, verificando-se que os genes estavam ligados na maioria dos ca sos. Também foram obtidos transformantes $n i f^{+}$de Escherichia coli, utilizando-se DNA de A. paspali, os quais apresentaram reduzida atividade de nitrogenase, avaliada pelare dução do acetileno. Estes transformantes iff $^{+}$foram ensaia dos posteriormente, em värios processos de conjugação, com linhagens de E. coli. A partir destes experimentos, podese verificar que o sistema estudado apresenta algumas si 
milaridades com outras espécies de Azotobacter, no que diz respeito à localização dos genes nif no genoma bacteriano. No entanto, a ocorrencia de transformantes $n i f^{t}$ de $E$. coli, sugere que a maioria dos genes nif funcionais estao em um grupo passível de ser transferido por um único segmento de DNA. 
GENETIC ASPECTS OF NON SYMBIOTIC NITROGEN FIXATION

IN SOIL BACTERIA

Gislene Garcia Franco do Nascimento

Flávio Cesar Almeida Tavares

Adviser

\section{SUMMARY}

In soil bacteria plasmidial and chromosomal

genes related to $\mathrm{N}_{2}$ fixation were screened and selected. for genetic studies and also to evaluate theirtransfer potential to other biological systems. The presence of plasmids were detected in the natural isolates 2-2II, 5-3 and 40-1 with molecular weight 64,40 and 92 Md respectively, determined by agarose gel electrophoresis. None of these strains had plasmidial fixation genes since after plasmidial elimination ("cure") growth remained normal in media without nitrogen. Best plasmid "cure" was obtained after $44^{\circ} \mathrm{C}$ temperature treatment $(2-10 \%)$ folowed by ethidium bromide $(1-5 \%)$ and the lowest elimination was obtained by acriflavin $(0,5-1 \%)$ 
and acridine orange $(0,2-0,8 \%)$. Variability was observed for the presence and plasmid size. One of the isolates (number 9), classified as Azotobacter paspali and a nitrogen fixer strain with no plasmid detected was studied geneticaly with the objective of nif genes location. Auxotrofic and non fixing mutants ( $\left.n i f^{-}\right)$were isolated after treatment by UV light and nitrous acid. Complementation analysis after genetic transformation of $n i f^{-}$mutants in al1 possible combinations permited to detect linkage for the markers under analysis. By genetic transformation it was possible to transfer the fixation ability of A. paspali to Escherichia coli, although with reduced nitrogenase activity as evaluated by acetilene reduction. E. coli transformants were evaluated after conjugation experiments with different $E$. coli strains. Regarding to nif genes location on the bacterial genome the studies revealed similarities with other Azotobacter species. However taking in account the transformation of $E$. coli for $n i f^{+}$suggests the possibility that most functional nif genes are clustered able to be transfered by a single DNA segment. 


\section{INTRODUÇÃO}

A genética dos organismos fixadores de nitrogênio atmosférico, apesar de ser um estudo relativamente re cente, vem fornecendo notável contribuição para o acervo de conhecimentos sobre a fixação. De grande destaque são os as pectos moleculares determinantes deste processo onde em alguns casos tem sido possivel elucidar o arranjo dos genes para a fixação (nif) e sua regulação.

Neste sentido, destacam-se os estudos com a bactéria Klébsiella pneumoniae, onde se tornou evidente que a maioria dos genes nif são ligados e portanto contidos num $\underline{\underline{u}}$ nico segmento, que pode ser clonado em plasmídios e assim ob tido. em muitas cópias. No entanto, esta bactéria não pode ser utilizada diretamente na agricultura, por nao ser típic a de solo.

Outra bactéria fixadora assimbiótica de nitro gênios ocupando um lugar de destaque,é a Azotobacter vinelandii, 
esta típicadesolo. Embora não tenha sido definida a posição dos genes nif neste microrganismo, há indicações de que não es tejam todos num único grupo de ligação, dificultando a trans férência conjunta ou mesmo amplificação em plasmídios.

Alēm destas bactérias são também importantes as do gênero Rhizobium, que desenvolvem uma simbiose com le guminosas realizando uma suplementação de nitrogênio direta aos vegetais. Apesar da importância do processo desenvolvi do por esta bactéria, deve ser considerado que a maioria das mo dificações genéticas obtidas só podem ser realmente avaliadas após experimentos em simbiosecomas plantas hospedeiras.

Como pode ser observado, os sistemas de fixa ção de nitrogênio até então disponíveis, apresentam certas dificuldades, seja pela complexidade da simbiose (requerendo a interação dos genomas bactéria e hospedeiro), seja pe10 fato dos genes fixadores estarem dispersos no genoma de bactērias assimbióticas. Em vista destes fatos, o objetivo do trabalho foi o de isolar um sistema de fixação de $\mathrm{N}_{2}$ assimbiótico mais favorável para estudos genéticos a partir de diferentes amostras de solos. Procurou-se nestes isolados, bactérias que permitissem uma fácil manipulação em laborató rio, além de possuir genes nif capazes de serem transferidos para outros sistemas não fixadores, através de píasmí dios ou mesmo segmentos de DNA cromossomais. 


\section{REVISÃO DE LITERATURA}

Em vista dos objetivos deste trabalho, foi feita uma revisão sobre a genética do genero - Azotobacter, onde uma introdução se fez necessāria, para melhor compreen são das reações básicas do processo de fixação de $\mathrm{N}_{2}$. Ainda foi revisada a ocorrência de plasmídios, bem como suas implicações em bactérias fixadoras de $\mathrm{N}_{2}$.

2.1. Considerações gerais sobre a fixação de nitrogênio em organismos de vida livre

o nitrogênio é um constituinte essencial das proteínas e portanto indispensável para todas as formas de vida. Representa um fator 1 imitante para o crescimento de plantas e animais e um suprimento inadequado na agricultura pode ser considerado como uma das causas da escassez de al $\underline{i}$ mentos no mundo. 
Cerca de $78 \%$ da atmosfera é constituídadenitrogênio molecular e no entanto, plantas, animais e eucariotos em geral não podem converter esse gás diretamente em uma forma biologicamente utilizável. Na natureza, o $N_{2}$ pode ser fixado por alguns microrganismos que o convertem para a forma de amônia, a qual pode posteriormente ser aproveitada pelos vegetais. Nenhum organismo superior tem esta capacidade, embora muitos deles participem indiretamente formando associações simbióticas capazes de fixar nitrogênio.

Desta forma, justifica-se o grande interesse despertado na ūltima década em se melhor elucidar o processo de fixação biológica do nitrogênio. Trata-se de uma importante alternativa agrícola, principalmente quando se conside ram os gastos necessários para produzir a mesma quantidade de nitrogênio na forma de fertilizantes. Deve-se ainda considerar que a utilização em grande escala desses fertilizantes concorre para o aumento da poluição de àguas naturais (QUISPEL, 1974 ).

Dentre os organismos fixadores de nitrogênio de vida livre, destacam-se os gêneros Klebsielza, Azotobacter e Azospirizzum. Outras espécies de bactērias, certos actinomicetos e algas verde-azuladas também possuem característica, mas pouca menção é feita na literatura à respeito da genética destes microrganismos. 
Em todos os organismos fixadores, as reações básicas parecem ser as mesmas, istoé, a redução do nitrogê nio para amônia através da complexa enzimanitrogenase (BRILL, 19.81). A atividade da nitrogenase em A. vinelandii (BULEN et alii, 1964; BULEN e LE COMTE, 1966; SHAL e BRILL, 1973), como também de outros organismos fixadores, requer duas proteínas solūveis, designàdas como componentes I e II (MORTENSON et alii, 1967; EADY e POSTGATE, 1974; EMERICH e BURRIS, $1978)$

O componente I também chamado de Fe-Mo-proteí na já foi cristalizado (BURNS et alii, 1970), sendo um tetrâa mero de $245 \mathrm{kd}$, contendo dois àtomos de molibdênio por molécula e duas subunidades, $\alpha_{2} \beta_{2}$ (SWISHER et ali $i, 1977$; SHAL e BRILL, 1977; KENNEDY et alii, 1976). A anālise de aminoācidos demonstrou que há similaridade entre as subunidades. Apesar da carboxila dos aminoācidos terminais das duas subuni dades de A. vinelandii do componente I serem diferentes, parece possível que estas resultem de modificações de um simples polipeptídeo (LUNDELl e HOWARD, 1978). Cada subunidade requer a outra para sua estabilidade. Quando uma mutação em um gene origina um produto instável, o produto do outro gene é rapidamente degradado (ROBERTS et alii, 1978).

o componente II, também designado como. Fe proteína ou nitrato redutase, é um dimero formado de duas subunidades idênticas de $31 \mathrm{kd}$, contendo 289 aminoácidos (HA- 
GEMAN e BURRIS, 1978; HAUSINGER e HOWARD, 1980), cuja sequên cia já foi determinada por TANAKA et a $i$ i (1977a,b) e ROBERTS et alii (1978). Entre os diferentes organismos, hà similari dade na nitrogenase (CHEN et a $i$ i , 1973; EADY e POSTGATE, 1974). Destaforma, o componente I de um gênero pode intera gir com o componente II de outro, para produzir uma enzima tiva (BENSON et alii, 1971; BIGGINS et alii, 1971; DETROY et alii, 1968; KELLY, 1969b; THORNELEY et alii, 1975; TSAI e MORTENSON, 1978). 0 antissoro preparado a partir de um componente de um determinado organismo pode reagir com componen tes isolados de bactérias de diferentes gêneros (MAIER e BRILL，1976).

A fixação de nitrogênio só ocọrre quando as bactērias são incapazes de obter nitrogênio de outras fontes. Deste modo, $\mathrm{NH}_{4}^{+}$inibe completamente a formação de nitrogenase e compostos como aspartato, glutamato reprimem par cialmente. Quando uma cultura de célula cresce em meio isen to de nitrogênio incorporado, é induzida a produção de nitro genase, e o $\mathrm{NH}_{4}^{+}$produzido é convertido pelas enzimas glutamina sintetase e glutamato sintetase a glutamato, que é usado nas biossinteses celulares (NAGATANI et a $i$, 1971; SHANMUGAM e MORANDI, 1976 ).

Em relação à presença de oxigênio, pode-se dị zer que a enzima nitrogenase é extremamente sensível a este gäs, sendo que ambos os componentes são irreversivelmente i- 
nativados quando expostos ao ar (ROBSON e POSTGATE, 1980). Desta forma, a fixação de nitrogênio é mais comum entre bactérias anaeróbias do que aerōbias. Anaeróbios obrigatórios, tais como espécies de Clostridium pasteurianum, Chromatium, ChIorobium, Desulfovibrio e Desulfotomaculum podem fixar $\mathrm{N}_{2}$ : (YATES e JONES, 1974). Alguns anaeróbios facultativos, também fixam $\mathrm{N}_{2}$ sob condições de anaerobiose, tais como BacilZus polymixa, B. macerans, Klebsiella pneumoniae e ainda a 1gumas espécies de bactérias fotossintéticas como Rhodospirillum, Rhodomicrobium e Rhodopseudomonas.

A fixação de $\mathrm{N}_{2}$ entre espécies aeróbias está restrita à família Azotobacteriaceae, que inclui espécies de Azotobacter, Azomonas, Beijerinckia e Derxia, além de algumas espécies de Mycobacterium (SPRENT, 1979). Há espécies que fixam $\mathrm{N}_{2}$ em ambiente com baixa tensão de $\mathrm{O}_{2}$ (microaerófi 1as), comoé o caso da bactéria AzospipizZum (BRILL, 1977).

\subsection{Aspectos genéticos da fixação de nitrogênio no gênero} Azotobacter

Para o estudo genético de bactérias fixadoras de $\mathrm{N}_{2}$, deve se dispor de mutantes, bem como de técnicas adequadas para sua anālise. Além disto, deve-se contar com sis temas de transferência de material genético de células doado ras para receptoras, com a finalidade de mapear tais muta- 
ções, como conjugação, transformação e transdução. Assim, a genética tem contribuido muito na elucidação do processo de fixação de $\mathrm{N}_{2}$, principalmente considerando-se os recentes avanços da técnica do DNA recombinante, que abriu novas perspectivas no sentido de transferir os genes nif para organismos não fixadores.

Embora a genética da fixação de nitrogênio tenha se iniciado em Azotobacter (FISHER e BRILL, 1969; SORGER e TROFIMENKOFF, 1970), um maior conhecimento a respeito dos genes nif envolvidos nesse processo, foi possível a partir de estudos em K. pneumoniae. Nesta espécie, a existência de um sistema eficiente de transdução (KENNEDY, 1977) e o isolamento do.plasmídio pRDl (DIXON et alii, 1976) contendo o grupo de genes nif, foi muito ütil na compreensão do processo de fixação de $\mathrm{N}_{2}$ (BRILL, 1980). Nestes estudos, foi verí ficado que a maioria dos genes nif são ligados e estão próxi mos ao operon his (DIXON et a $i$ i, 1972), sendo identificados 17 genes nif em 7 unidades de transcrição (SIBOLD, 1982); nif HDK são genes estruturais para a nitrogenase; nif H codifica para a subunidade simples do componente II e nif DK para as duas subunidades do componente I, sendo os três genes e o nif Y transcritos na ordem nif HDKY.

o gênero Azotobacter foi classificado por Bei jerinck em 1901 e os primeiros estudos genéticos e bioquímicos a respeito da fixação de $\mathrm{N}_{2}$ foram realizados com $A$. vi 
nelandii e A. chroococcum (STUMBO e GAYNEY, 1938; WYS e WYSS, 1950; GREEN et alii, 1953). No entanto, vārios fatores como perda dos mutantes ou instabilidade associados com técnicas impröprias, resultaram em um lento avanço na genéti ca dessas bactérias.

As 1 inhagens mais utilizadas são: A. vinelan dii OP (ATCC 13705; ATCC 478; ATCC 12837), OP também chama da UW, que è um mutante não capsulado obtido da linhagem 0 (ATCC 12518), e A. chroococcum (NCIB 8003).

STUMBO e GAINEY (1938) isolaram mutantes de A. chroococcum incapazes de fixar $\mathrm{N}_{2}$ ( $n i f^{-}$) através do crescimento da cultura por vários meses em meio contendo altas concentrações de $\mathrm{NO}_{3}^{-}(4000 \mathrm{ppm})$ como ünica fonte de nitrogênio. Estes mutantes não apresentaram deleção, pois foram capazes de fixar $\mathrm{N}_{2}$ apōs värias passagens em meio sem nitrato. Segundo estes autores, o crescimento sob estas condições pode ter originado ácido nitroso intracelular, que atuou como mutagênico.

Apōs irradiação com luz ultra-violeta, WYSS e WYSS (1950), obtiveram mutantes nif em A. vinelandii, tendo sido observadas algumas características alteradas, tais como morfologia, produção de pigmentos e habilidade para reversão. GREEN et alii (1953) obtiveram do mesmo modo mutantes nif- de A. vinelandii, com postërior seleção em penicilina. os mutan 
tes $n i f^{-}$obtidos por MUMFORD et alii (1959) não apresentaram mutação no gene envolvendo a síntese de nitrogenase,pois a adição de vārios precursores do piruvato ou lactato, supri miram esta condição.

BUSH e WILSON (1959) isolaram mutantes de A. vinelandii linhagem 0 , que não formaram colônias mucosas. Es tes foram designados como OP, sendo muito utilizados em expe rimentos posteriores com a nitrogenase devido à facilidade de sua manipulação. Mutantes desreprimidos para a síntesedeni trogenase em $A$. vinelandi $i$, foram selecionados por SORGER (1968), através da resistência a inibidores como metilalanina ou metilamina, compostos tidos como correpressores. Entretanto, ST JOHN e BRILL (1972) não observaram inibição ou desrepressão da nitrogenase em mutantes resistentes a estes compostos. Evidências deste fato tambēm foram dadas por GoRDON e BRILL (1972), que obtiveram mutantes desreprimidos para a sintese de nitrogenase, mas que ainda foram sensíveis ao efeito inibidor da metilamina.

A seleção de mutantes $n i f^{-}$temperatura-sensíveis foi feito por BENEMAN et a $i$ i (1971), tratando as células com nitrosoguanidina e depois incubadas a $39^{\circ} \mathrm{C}$. Verificaram que nenhum dos mutantes $n i f^{-}$isolados foram temperatura-sensiveis para qualquer um dos componentes da nitrogenase.

Mutantes $n i f^{-}$isolados da linhagem de $A$. vine 
Zandii UW (SHAL et alii, 1973) foram analisados bioquimicamente para: atividade dos componentes da nitrogenase por com plementação com componentes I e II puros; produção de antissoro para cada componente da nitrogenase (DAVISet alii,1972); sinais de ressonância eletrônica paramagnética (EPR) proporcionando uma estimativa da quantidade de componente II funcional (NAGATANI et alii, 1974) e coloração de ferro após a migração de extratos celulares em géis não desnaturados (BRILL et alii, 1974 ).

De acordo com as caracteristicas bioquímicas, os mutantes $n i f^{-}$puderam ser distribuidos em seis grupos:

(a) mutantes regulatórios, tais como UW1 (FISHER e BRILL, 1969) e UW2 (SHAH et alii, 1973), que perderam a atividade para ambas as nitrogenases, comprovados por colo ração de ferro e teste com antissoro (CRM) (BRILL et alii, 1974).

(b) mutantes como UWlo com genes estruturais deficientes para o componente I (subunidade $\alpha$ ou $\beta$ ), que não foi ativado pelo complexo Fe-Mo-Co, mas que produziu componente II ativo (SHAH e BRILL, 1977).

(c) mutantes deficientes no componente I, como UW45, que ao conträrio de UW10, pode ser reativado por FeMo-Co (NAGATANI et alii, 1974; PIENKOS et alii, 1981). 
(d) mutantes para o gene estrutural do componente I como o tipo selvagem e uma Fe-proteína inativa (SHAH et a.zii, 1973).

(e) mutantes como o UW38, que superproduziu o componente I e ainda apresentou componente II ativo (SHAH et alii, 1974); esta mutação foi mapeada muito próxima da muta ção UW6 (BISHOP e BRILL, 1977b), que apresentou o mesmo fenó tipo, mas não produziu o componente II. A mesma mutação foi responsável pela superprodução do componente II e ausência do I, o que foi explicado como sendo revertentes expontâneos nif $f^{+}$ da 1 inhagem UW38.

(f) mutantes que não produziram o componente I e apresentaram baixa atividade do I, como a 1 inhagem UW 3 .

Mutantes resistentes à rifampicina (PAGE e SADOFF, 1976b), tetraciclina e äcido nalidíxico (CANNON e Postgate, 1976) foram obtidos em A. vinelandii. No entanto, mutantes auxotróficos têm sido muito difíceis de serem isola dos (MISHRA e WYSS, 1969; SADOFF et alii, 1971). PAGE e SADOFF (1976b), após tratamento com nitrosoguanidina, isolaram mutantes auxotróficos para hipoxantina, adenina e uracila, porēm nenhum para aminoācidos.

$$
\text { De acordo com SADOFF et alii (1979), è possí- }
$$
vel que os aminoácidos não sejam metabolizados em Azotobacter, pois estes foram incapazes de crescer em meio contendo 
aminoácidos como fonte de nitrogênio. Entretanto, muitos análogos de aminoácidos foram capazes de inibir o crescimento de $A$ : vinelandii. outra possível explicação para a dificuldade em obterauxotróficos para aminoácidos é que esta bactéria pode ter no mínimo 40 cópias de cromossomos por célula. Se isto realmente acontecer, as enzimas necessärias para a biossíntese de aminoácidos são codificadas por genes, tendo muitas cópias por célula, enquanto genes nif e os que codifi cam purinas e pirimidinas têm poucas cópias por célula.

Na fase exponencial de crescimento, cada célu 1 a contém quatro corpúsculos nucleares de acordo com observa fões feitas por WISS e WISS (1950) e SADOFF et ali Entretanto, foi encontrado apenas um corpúscuilo nuclear no cisto, o que está de acordo com a segregação nuclear observa da no final da fase exponencial de crescimento. Segundo SADOFF et alii (1971), estudos de renaturação de DNA, mostraram que o comprimento médio do cromossoma de Azotobacter foi similar ao de $E$. coli. No entanto, medidas da quantidade de DNA por célula deram um valor de $3,4 \times 10^{-14}$ gramas por corpúsculo nuclear, istoé, dez vezes mais DNA do que deE. coli (SADOFF et alii, 1971).

TERZAGHI (1980b), examinando a taxa de sobrevivência de $A$. vinelandii após irradiação com ultra-violeta, observou que esta foi semelhante a de $E$. coli, o que discorda dos dados de que Azotobacter possui dez vezes mais DNA por 
célula: De acordo comeste autor, a maioria das cópias dos cromossomas não são biologicamente funcionais.

Organismos que fixam $\mathrm{N}_{2}$ em aerobiose, como $A-$ zotobacter, devem ter um sistema muito eficiente de proteção de sua nitrogenase. BULEN et a $i i i$ (1964) e KELLY (1969a) com provaram que extratos de células de Azotobacter são relativa mente estáveis em presença de oxigênio. Foi inicialmente su gerido que a tolerância a este gás foi devido a um particular estado da enzima, mas recentemente, experimentos sugerem a existência de um mecanismo alternativo. OPPENHEIN et a $i$ i (1970) e OPPENHEIN e MARCUS (1970) propuseram a hipótese de que a proteção contra oxigênio foi devida a uma membrana citoplasmática extra que aparece em organismos crescendo em meios isentos de fontes de nitrogênio.

HAAKER e VEEGER (1977) demonstraram a presença de um fator proteico que forma um complexo estável entre o oxigênio e componentes da nitrogenase. Este fator foi purificado e mostrou ser uma proteína contendo ferro e enxôfre com peso molecular de $24 \mathrm{kd}$ (SHEERINGS et alii, 1977). Uma. proteína com função semelhante de 14 kd foi purificada de $A$. chroococcum (ROBSON, 1979).

Assim, Azotobacter fixa nitrogênio em presença de ar, embora aeração excessiva iniba a atividade da nitrogenase (DALTON e POSTGATE, 1969; LEES e POSTGATE, 1973). 
Sensibilidade ao oxigênio foi atribuida a uma adaptação da a tividade respiratória das células ou seja, uma alta atividade respiratória rapidamente reduz $0_{2}$ (SMITHetalii, 1976), re sultando numa baixa concentração interna deste gäs. … Para manter a alta atividade respiratória, uma fonte de carbono adequada deve ser fornecida. Se o fluxo de elétrons é limitado, há proteção de sua nitrogenase, através da combinação dos componentes I e II com outra proteína Fe-S. A observação de que $A$. vinelandii em excesso de $0_{2}$, consome mais carbono do que o necessário para satisfazer suas necessidades de crescimento, levou PHILlips e Johnson (1961), citados por ROBSON e POSTGATE (1980), a propor um sistema de respiração com resíduo de $\mathrm{O}_{2}$.

Dois mecanismos de proteção da nitrogenase fo ram propostos de acordo com estás observações: proteção da respiração e uma mudança na conformação da estrutura da' nitrogenase (DROZD e POSTGATE, 1970), sendo este ültimo mecanismo devido a um fator estabilizante do oxigênio (ROBSON e POSTGATE, 1980). Além disto, foi demonstrado que a biossíntese da nitrogenase em $A$. chroococcum $\vec{e}$ reprimida por oxigênio, como em K. pneumoniae (ROBSON, 1979, citados por ElME RICH, 1984 e HILL et a $i$ i, 1981).

Outras características além da aeração, devem ser observadas tais como fonte de nitrogênio e molibdênio. o nitrogênio molecular não é um indutor da biossintese dani- 
trogenase e amônia parece ser um repressor (DALTON e PostGATE, 1969). Entretanto, a amônia não é um repressor direto e necessita ser metabolizada, uma vez que a repressão è dada pela metionina sulfoximina, um inibidor da assimilação da amônia (GORDON e BRILL, 1974), estando bem elucidade em inúme ros trabalhos (DALTON e POSTGATE, 1969; DIXON, 1972; RIVERAORTEZ e BURRIS, 1975; BERNDT et alii, 1976). Assim, a nitro genase näo foi sintetizada quando amônia ou outra fonte de nitrogênio assimilàvel foi acrescentada a meio em qualquer das citações.

Quando amônia foi acrescentada em baixas concentrações, houve inibição parcial da atividade da nitrogena se (DROZD et alii, 1972; GORDON et alii, 1981), o que foi ex plicada por LAANE et alii (1980) como sendo devida a alterações nas propriedades elétricas da membrana. Em bactérias fotossintéticas, esta inibição não foi resultado da modifica ção covalente no componente II da enzima (ZUMFT et alii, 1981, citados por ELMERICH, 1984), ocorrendo modificações deste tí po em Azospirizlum. Isto foi demonstrado pela necessidade de um fator de ativação em extratos crus de células e ainda a inativaçãó "in vivo" da atividade da nitrogenase após adição de $50 \mu$ de amônia (LUDDEN et ali $i, 1978$ ).

Em relação ao molibdênio, pode-se dizerque jā se reconhece há muito tempo, a sua essencialidade para a fixação de nitrogênio (EADY et alii, 1978; NAGATANI e BRILL, 
1974). Quando A. vinelandii foi crescida em meio deficiente de molibdênio, mas contendotugstato, esta produziu um componente I inativo, o qual pode ser reativado "in vivo" pela adição de Fe-Mo ao meio de cultura (NAGATANI et alii, 1974). Reativação por molibdato também foi conseguida e neste caso, ATP e um fator adicional de baixo peso molecular (entre 2000 e 4000) foi necessário para a reativação (PIENKos et alii, 1981).

Uma proteína contendo molibdênio foi detectada por PIENKos e BRILL, (1981), tanto em meio de crescimento com ou isento de nitrogênio incorporado. Esta proteína continha dois tipos de subunidades de 21 e $24 \mathrm{kd}$, com uma organização tetramērica com capacidade de ligação. com pelo menos 14 ảtomos de molibdênio por molécula.

Em trabalhos mais recentes, foi proposto um sistema alternativo de fixação de $\mathrm{N}_{2}$. BISHOP et alii (1980) obtiveram pseudorevertentes $n i f^{+}$a partir das 1 inhagens $n i f^{-}$ UW6 e UW10 (SHAL et alii, 1973), que mantiveram as mutações originais nif 6 e nif 10 das linhagens parentais. Estes pseudorevertentes apresentaram crescimento em meio isento de nitrogênio incorporado, em taxa menor do que o tipo selvagem e reduzirăm acetileno 3 a $4 \%$ em relação ao controle nif $f^{+}$. Fo ram produzidas quatro proteínas amônia-repressoras detectadas por eletroforese. Alēm disto, foi observada reversão fe notípica para $n i f^{+}$de uma série de mutantes $n i f^{-}$quando cres 
cido em meio sem molibdênio, mas contendo tungstênio e vanadio (BISHOP et alii, 1982). Sob estas condições, os mutantes reduziram acetileno numa baixa taxa, não apresentando po rém os sinais típicos de EPR do componente II. Essas observações levaram os autores a propor a existêncià de um metabolismo alternativo de fixaçäo de nitrogênio em A. vinelandii que funciona independentemente da presença de molibdênio da se guinte forma:

1) O sistema alternativo de fixação de $\mathrm{N}_{2}$ é co dificado pelo mesmo grupo de genes nif usado para o sistema convencional da nitrogenase e quatro proteínas diferentes se originam após a tradução do conjunto de proteínas, no ú1timo sistema.

2) Os genes nif para o sistema alternativosão distintos daqueles que codificam para a nitrogenase no siste ma convencional.

3) Há possibilidades de que alguns dos genes nif estão distribuidos entre ambos os sistemas, enquanto que há outros genes específicos para o sistema alternativo.

o primeiro processo de transformação em Azotó bacter foi descrito por SEN e SEN (1965), que realizaramtrans formação interespecífica entre $A$. vinelandiie A. chroococcum para produção de pigmento. A partir disto, foram desenvolvi das melhores condições de transformação em A. vinelandii uti 
lizando marcas genéticas.

PAGE e SADOFF (1976a) desenvolveram um método de transformação em placas de Petri, onde preparações crus de DNA (1isados de células) foram espalhadas diretamente sobre as bactérias receptoras. Deste modo, bactérias não competentes ficaram em contato com o DNA até o estágio de compe tência ser obtido. Foi conseguida a transformação para prototrofia de inūmeras mutações auxotróficas (uracila, adenina, hipoxantina), nif e rifampicina, estabelecendo-se a 1igação gênica entre estas marcas (BISHOP e BRILL, 1977). Verificaram que havia ligação nos genes das linhagens mutantes que perderam simultaneamente os componentes I e II, com o de vários mutantes incapazes de sintetizar o componente I. Pelos resultados, os autores sugerem que os genes nif não estão todos no mesmo grupo em $A$. vinelandii, mas não estabele ceram posições mais definidas destes genes, no genoma da bac téria.

Este método em placas, também foi usado para transformar Azotobacter com DNA de Rhizobium. Neste processo de transformação intergenérico, $10 \%$ dos transformantes $n i f^{+}$também continham o sítio de ligação a lectina, que especifica a relação entre Rhizobium e a planta hospedeira, quando se utilizou a espécie $R$. trifolii (MAIER e BRILL, 1976). No entanto, nenhum transformante foi capaz de nodular com raízes de trevo (MAIER et ali i, 1978). 
Foram também examinados os fatores que influenciam a competência, utilizando o mesmo método da placa, mas o tempo de exposição ao DNA foi controlado pela adiçãode DNA se (PAGE e SADOFF, 1976b; PAGE e von TIGERSTROM, 1978). A1ēm disto, um meio de crescimento sem adição de ferro foi utilizado para se obter o máximo de competência. Segundo corBIN e BULEN (1969.), a utilização de um mero deficiente emfer ro originou o aparecimento de um pigmento fluorescente carac terístico de $A$. vinezandii. Entretanto, produção de pigmento nem sempre esteve associada com competência (PAGE e von TIGERSTROM, 1978). O máximo de competência foi observada em meio isento de ferro quando pelo menos $0,5 \mathrm{mM}$ de cálcio foi adicionado (PAGE e DORAN, 1981). Verificaram também, que a glicose pode ser substituida por outras fontes de carbono, tais como manitol, g1icerol ou sacarose.

PAGE e von TIGERSTROM (1979) desenvolveram técnicas especiais para o processo de transformação em Azoto bacter, onde o meio de incubação requeria pelo menos $8 \mathrm{mM}$ de magnésio, que não pode ser substituido por cálcio. A frequência de transformação em placas ocorreu em torno de $10^{-4} \%$ e em meio líquido variou de $10^{-2}$ a $10^{-3} \%$. Em relação ao pro cesso de transformação em si, nenhuma característica foi con siderada. As proteínas envolvidas na competência foram isoladas a partir de sobrenadantes de culturas de células, onde foi induzida competência em meio isento de ferro (PAGE e Do- 
RAN, 1981). Foi isolada uma glicoproteína de $60 \mathrm{kd}$, correspondente a um envoltório proteico de $A$. vinelandii (SCHENK et alii, 1977) e também.uma outra proteína essencial na competência, obtida em cultura isenta de cálcio e ferro.

DAVID et alii (1981) desenvolveram um método de transformação com plasmídios, adaptado da técnica de tratamento com $\mathrm{CaCl}_{2}$ usada para $E$. coli (COHEN et ali $i, 1972$ ). Plasmídios RP4 (grupo Inc P1) (DATTA e HEDGES, 1971), RS1010 (grupo Inc) (GUERRY et alii, 1974) e seus derivados, foram transferidos para $A$. vinelandi $i$. Os transformantes foram es táveis e todas as marcas conferindo resistência a drogas se expressaram. 0 máximo de frequência de transformação foi $10^{-5} \%$ quando as células receptoras foram trat.adas com $0,2 \mathrm{M}$ de $\mathrm{CaCl}_{2}$

Além do processo de transformação, värios tra balhos são descritos com relação à transdução. Os azotofagos (fagos de Azotobacter) estão distribuidos em cinco grupos sorológicos não relacionados: 4 deles foram identificados por DUFF e WYSS (1961) e o outro por CHUML et alii (1960). Todos os fagos isolados formaram placas de lise claras com halos turvos, apresentando diâmetros variados entre eles. Um fago representativo de cada grupo sorológico foi estudado: A14 (Grupo I), A21 (Grupo II), A31 (Grupo III), A41 (Grupo IV) e PAV-1 (Grupo V). Todos os fagos da série A foram isolados da linhagem de A. vinelandii O (DUFF e WYSS, 1961; MON 
SOUR et alii, 1955). Estes fagos se limitaram a infectar $A$. vinelandii e A. chroococcum e não formaram placas de 1 ise nos gêneros Azomonas e Beijerinckia. Porém, esta sērie de fagos não formou placas de 1 ise em linhagens não capsuladas, tal como a OP. Entretanto, SORGER e TROFIMENKOFF (1970) e BISHOP et alii (1977b) isolaram fagos característicos da linha gem OP, e entre estes, o fago PAV-1 que infectou tanto a 1 i nhagem 0 como OP.

Todos os 5 grupos de fagos eram constituidos por DNA de fita dupla com peso molecular de 160 Md para A14 (THOMPSON et alii, 1973); 42 Md para A21; 47. Md para A31 (DOMINGO et alii, 1972) e 29 Md para PAV-1, e pertenciam a três tipos morfológicos descritos por BRADLEY (1967). Todos os grupos tinham cabeças poliédricas, tipo icosaédricas, es fagos A21, A41 e PAV-1 tinham pequena cauda não conträtil (KNOVIKA et alii, 1972). Os fagos A31 e A14 tinham longa cauda contrátil. Os outros fagos mencionados por FISHER e BRILL (1969) e BISHOP et a $i$ i (1977b) não foram caracteri$z$ ados .

Os cinco grupos de fagos não apresentaram 1 isogenia estäve1, mas foram responsāveis pela conversão pseudolisogênica de seus hospedeiros (THOMPSON et a $i$ i, 1980a,b). Foi observado que após a infeç̧ão da linhagem de $A$. vinelandi $i$ o posterior plaquemento dos sobreviventes, houve apare cimento de grande quantidade de colonias rugosas amarelas e 
não mucosas, sendo que as células perderam seu revestimento de polissacarídeo, tornando-se flageladas e móveis. As célu las recombinantes foram semelhantes aos mutantes op não capsulados (BUSH e WILSON, 1959), os quais foram imunes a outras infecções fägicas, exceto para o fago PAV-1. Segundo THOMP SoN et a Ii (1980a), quando essas células cresceram em presença do antissoro fágico, três tipos de resultados foram ob tidos: (a) células hospedeiras, capsuladas e ainda sensíveis aos 5 grupos de fagos; (b) "Pseudolisógenos", fenotipi camente recombinados, produzindo fagos e capazes de segregar com células capsuladas do tipo selvagem; e (c) células recombinantes estáveis, que foram resistentes ao. fago A, mas ainda sensíveis ao PAV-1, incapazes de produzir fagosede se gregar células capsuladas do tipo selvagem. Sensibilidade ao fago PAV-1 não foi surpreendente, uma vez que o fago pode infectar tanto células capsuladas como não capsuladas.

A necessidade da cápsula para infecção de fagos do grupo A foi posteriormente confirmada, através da digestão desta, por uma depolimerase, quando então, nenhuma ad sorção do fago A21 pode ser detectada. Foram observadas 4 có pias do fago em pseudolisógenos e menos do que 0,2 cópias em células recombinantes estäveis, o que não pode ser explicado (THOMPSON et alii, 1980b).

Transdução com azotofagos foi mencionado inicialmente por WYSS e NIMECK (1962), citados por ELMERICH 
(1984), mas nenhuma confirmação foi publicada. Entretanto, BISHOP et ali $i$ (1977b) isolaram 21 fagos que formaram placas de 1 ise em A. vinelandii oP e 8 da linhagem ATCC 12877, mas não observaram transdução entre eles.

Através do estudo de mutantes regulatórios, GORDON e BRILL (1972) sugeriram a existência de um gene regü latório comum que controla a expressão dos genes estruturais da nitrogenase. Isto foi proposto em vista da observação de que entre revertentes da 1 inhagem UW2 (incapaz de sintetizar os componentes da nitrogenase), alguns mostraram ser parcia 1 mente constitutivos.

Para explicar as propriedades da 1 inhagem UW38 (superprodutora do componente II, mas sem o I), SHAH et a $i \dot{i}$ (1974) propuseram um gene regulador comum, ao observarem que esse mutante quando desreprimido por oito horas, produziu cerca de cinco vezes mais componentes II. Provavelmentea 1 i nhagem UW38 apresentou duas mutações: uma causando super pro dução do componente II e a outra, incapacidade para sintetizar o componente I. Para testar esta hipótese, foram isolados revertentes expontâneos deste mutante que fixavam nitrogênio, mas apresentando baixas quantidades dos componentes I e II. Isto indicou que uma simples mutação causou o fenótipo da 1inhagem UW38. Desta forma, segundo os autores, é possível que estes componentes sejam codificados por mais de um operon, tendo operadores que respondem a um simples ativa 
dor. Este ativador poderia ser modificado por mutação, de mo do que ele não poderia se ligar a um operador do gene especi ficando o componente $I$, mas que este mesmo ativador poderia ser mais eficiente na ativação da transcrição do componente II:

Um modelo simplificado desta teoria (Figura 1) foi proposto por BRILL (1976). Neste modelo, há pelo menos dois operons codificando para componentes I e II, havendo possibilidade de que um operon seja necessário para ativar a síntese de cada uma das subunidades do componente $I$.

.0 gene $n i f C$ produz constitutivamente uma pro teína ativadora $A$, que pode existir em duas formas estruturais $A^{\prime}$ e $A^{\prime \prime}$. A forma $A^{\prime}$ se ligaria ao operador para compo nente I, mas não para II, podendo haver reversão para ${ }^{\prime}$ '. Pa ra ocorrer transcrição do gene, o ativador deveria se ligar a um operador. Acūmulo do efetor (por exemplo, $\mathrm{NH}_{4}^{+}$) no cito plasma, inativaria a proteína ativadora através de uma mudan §̧a na sua conformação para $A^{*}$, impossibilitando sua interação com o operador, não ocorrendo portanto, síntese de qualquer componente. Este modelo mostra que as mutações UW2 e UW38 estão 1 igadas no mesmo gene nif C.

Em K. pneumoniae, onde o processo de regulação dos genes nif está bem estudado, dois mecanismos regulatórios foram identificados: um mecanismo específico, que en- 


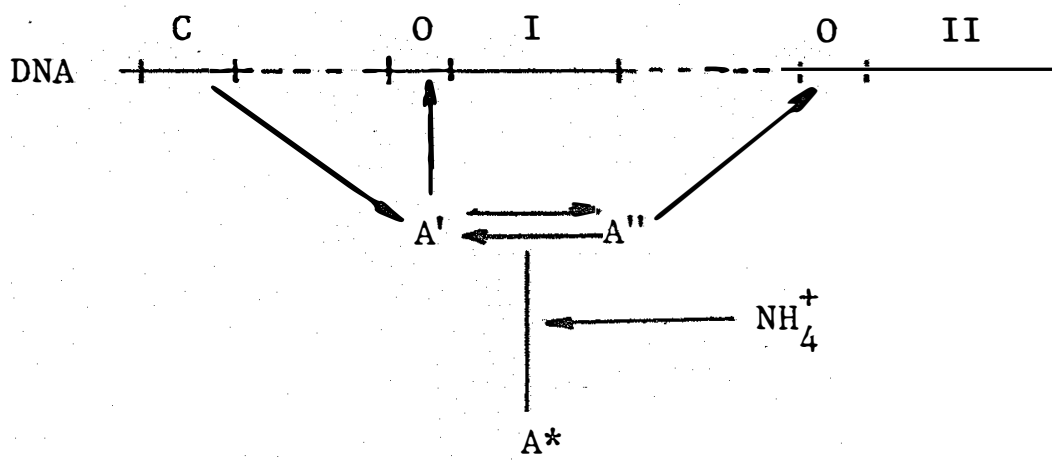

FIGURA 1 - Modelo simplificado para o controle positivodan $\underline{i}$ trogenase em $A$. vinelandii - nif $\mathrm{C}$, gene contro lador; 0, operador; I, gene para componente I; - II, gene para componente II; $A^{\prime}$ e 'A'', proteínas ativadoras; $A^{*}$, proteína ativadora inativa.

volve o produto da unidade de transcrição do nif LA (o prodü to do gene A sendo um ativador e o produto do gene nif L, um repressor) e o outro é não específico, envolvendo genes gln (BUCHANAN-WOLASTON et ali $i, 1980$; VOLPON et alii, 1981; MERRICK, 1982). ESPIN et alii (1982), ainda consideram um possível envolvimento e identificação dos genes análogos a gln F, glnG e gln L, também designados ntr A, ntr B e ntr C em Azotobacter.

DIXON et alii (1976) estudaram a possibilida- 
de de complementação intergenérica usando plasmídios carregando genes nif de K. pneumoniae introduzidos por conjugação em Azotobacter. CANNON e POSTGATE (1976), utilizando oplasmídio pRDl, observou complementação deste com alguns mutantes nif de A. vinelandii. A habilidade de Azotobacter em transcrever e traduzir genes nif de Klebsielza fez os auto res proporem que o sistema regulatório da síntese de nitroge nase é comum às duas bactērias, mesmo ao nível molecular. A lém disto, genes nif de Klebsiella normalmente só atuam em am biente anaeróbico e sua transferência para Azotobacter permi te expressão em presença de $\mathrm{O}_{2}$.

A obtenção do plasmídio pCKl carregando o gene nif A de K. pneumoniae foi conseguida por KENNEDY e ROBSON (1983) e quando introduzido em A. vinelandii ou A. chroo coccum selvagem, conferiu a capacidade de fixarnitrogênio em presença de amônia. Assim, o papel do efetor positivo do ge ne nif A demonstrado em $K$. pneumoniae, pode ser expresso em Azotobacter. Entretanto, mutantes regulatórios nif de $A$. vinelandii e A. chroococcum, tal como UWl, também fixaram ni trogênio em presença de amônia, quando receberam o pCK1. Foi ainda proposta a existência de um gene regulatório em Azotobacter, anälogo ao nif A de K. pneumoniae; e como nif A também apareceu como sendo um ativador da fusão $n i f H-1$ ac de $R$. melizoti em E. coli, SUNDARESAN et ali $i$ (1983) sugeriram que a atividade do gene A deve ser comum entre os fixadores de nitrogênio. 
o estudo de outras espécies de Azotobacter,tal como A. beijerincki e A. paspali ainda é inicial. A 1 guns trabalhos sobre A. paspali devem ser mencionados, principalmente considerando a associação desta com a rizosfera de Pas palum notatum (grama batatais). Esta associação, segundo DOBEREINER (1977), $\bar{e}$ estimulada pela excreção de carboidratos pela planta e amônia por Azotobacter.

A primeira citação a respeito de $A$. paspali foi feita por DOBEREINER (1966), quando esta espēcie foi des crita e classificada. Neste trabalho, foi encontrada a bactéria em 75 amostras de solo da rizosfera de P. notatum. MA CHADO e DOBEREINER (1969) fizeram vārios experimentos paraelucidar melhor a especificidade do efeito de P. notatum sobre o desenvolvimento de $A$. paspali, alëm de estudar outras características como efeito do $\mathrm{pH}$ e a natureza quínica do exsudato 1 iberado pelas raízes da grama.

värios trabalhos com A. paspalisão citados na literatura, visando maior esclarecimento sobre a associação entre grama-batatais - A. paspali (DOBEREINER et ali $i, 1972$, 1973; DOBEREINER, 1973; NEYRA e DOBEREINER, 1977 ; EVANS e BARBER, 1977; FRANCO et alii, 1978; WEIR, 1980; BODDEY et alii, 1983).

BAREA e BROWN (1975) e BROWN (1976) mostraram que em solução nutritiva, o tratamento de raízes de plântu- 
las com cultura de A. paspali, apresentaram um melhor cresci mento e aumento de peso foliar do que o controle sem inocula ção. Este efeito foi causado por reguladores de crescimento tais como ácido indol-acético, giberelinas e citoquininas, en contrados no sobrenadante. A atividade da nitrogenase não foi detectada na rizosfera de plantas jovens e sua ocorrência em plantas veilhas não foi associada necessariamente com a presença de A. paspali. Além disto, foi maior na rizosfera de plantas-controle do que em plantas inoculadas.

Em todos estes trabalhos, nenhuma menção foi feita a respeito da genética da fixação de nitrogênio por $A$. paspali.

2.3. Ocorrência de plasmídios em bactērias fixadoras de nitrogênio

A ocorrência de plasmídios tem sido descrita em värias espécies de bactérias fixadoras de $\mathrm{N}_{2}$, tanto simbiōticas (Rhizobium) quanto em assimbiöticas (Azospirizzum, Azotobacter, Beijerinckia).

FRANCHE et alii (1981) e FRANCHE e ELMERICH (1981) observaram a presença de 1 a 5. plasmídios em várias linhagens de Azospirillum com peso molecuar.variando de 3,5 a $300 \mathrm{Md}$. Nestes casos, nenhuma relação entre os plasmídios 
e as propriedades fenotípicas, em especial a fixação de $\mathrm{N}_{2}$, foi estabelecida. Em alguns casos, estes plasmídios foram purificados em gradiente de césio e foi feita a análise de restrição. os dois grupos taxonômicos A. brasilense e A. lipoferum não apresentaram diferenças com relação a- quantidade de plasmídios. Foi observada a perda de alguns plasmídios de modo expontâneo e também através de tratamento com agentes de"cura"como temperatura de $44^{\circ} \mathrm{C}$ e acridina Iaranja. Alteraçởs fenotípicas, tais como utilização de glicose, resis tência a metais pesados ou perda da capacidade de fixação de $\mathrm{N}_{2}$, foram observadas apos a perda de alguns plasmidios (LEMOS, 1980 e WOOD et alii, 1982, citados por ELMERICH, 1984).

Em Rhizobium, alguns genes envolvidos na nitrogenase bem como na simbiose, têm sido detectados em grandes plasmídios com peso"molecular entre 70 a $200 \mathrm{Md}$ (TSHITENGE et alii, 1975; NUTI et alii, 1977; BAFALVI et alii, 1981 e ROSEMBERG et alii, 1981). CASSE et alii (1979) isolaram 25 linhagens de $R$. melizoti de origens geográficas diferentes, das quais 22 carregavam pelo menos um grande plasmídio. Resultados similares foram encontrados por GROSS et a $i$ i (1979) onde classificaram vārias espécies de $R$. japonicum em 4 grupos com base nas diferenças de nümero e tamanho dos plasmidios, contendo esses grupos de 2 a 4 plasmídios por célula, com pesos moleculares variando entre 40 a 120 Md. 
BISHOP et alii (1977a) observaram que $R$. trifolii tinha genes para fixação de $\mathrm{N}_{2}$ num plasmídio, que também carregava genes para o polissacarídeo que se 1 iga à lectina, mostrando assim, que genes importantes neste processo, estäo relacionados com herança extracromossômica. Foi ainda demonstrado, que muitas funções simbióticas são codificadas por genes contidos em plasmídios e que a instabilidade de no dulação apresentada por muitas linhagens se deve à perda des ses plasmídios (HIGASHI, 1967; JOHNSTON et ali i, 1978; ZURKOWSKI e LORKIEWICZ, 1979; BEYNON et a $i$ i, 1980; BREWIN et alii, 1980 ; ZURKOWSKI, 1981).

Várias espécies de Azotobacter, como A. chroo coccum, A. vinelandii, A. beijerinckii e A. paspali, foram a valiadas quanto à presença de plasmídios. A maioria delas continham plasmídios de 10 a $100 \mathrm{Md}$, exceto para $A$. vinelan dii o e OP que não continham nenhum. Uma linhagem de $A$. chroococcum, não mucosa, continha 5 plasmídios com $7,45,50$, 80 e $115 \mathrm{Md}$. Estas espécies não apresentaram resistência a metais ou antibióticos e não foi verificado antagonismo com outras espécies de Azotobacter, com relação à produção de bac teriocinas ou fagos. Algumas destas, perderam o plasmídio após tratamento com acriflavina e continuaram a fixar $\mathrm{N}_{2}$.

o plasmídio pSA30, isolado por CANNON et a $i$ i (1979), citado por AUSUBEL (1980), continha o fragmento de 6,2 kb obtido com a enzima de restrição Eco Rl, composto pelos 
genes nif HDKY e parte do nifE de K. pneumoniae. Usando este fragmento como uma prova de hibridação, foi detectada homologia com DNA total de um grande nümerodeorganismos fixadöres de nitrogênio, inclusive $A$. vinelandii (RUVKUN e AUSUBEL, 1980; MAZUR et a $i$ i , 1980).

Em experimentos iniciais com A. vinelandii, 5 fragmentos de restrição EcoRl $\operatorname{com} 12,5,8,1,3,5,2,2$ e $0,8 \mathrm{~kb}$ hibridizaram com o padrão nif descrito acima. Homolo gia foi limitada aos genes nif $\mathrm{H}$ e nif $\mathrm{D}$ de $K$. pneumoniae e não ficou esclarecido porque somente fragmentos EcoRl hibridizaram com o padrão. Isto poderia ser explicado pela existência de pseudogenes, como descrito em Anabaena (RICE et alii, 1982), ou pela reiteração do gene nif, como em Rhizo bium phaseoli (QUINTO et alii, 1982).

Outra hipótese também sugerida por BISHOP et alii (1980) seria a de um metabolismo alternativo para a fixação de nitrogênio, conforme jā citado anteriormente. Entre tanto, mais recentemente, BISHOP e BOTT (1983) detectaram so mente três fragmentos de restrição EcoRl de 1,4, 2,6 e 4,1 kb que hibridizaram com o padrão nif p5A30. O fragmento de $4,1 \mathrm{~kb}$ foi clonado no plasmídio pBR325 para produzir plasmídios pBL1 e pBL3. O plasmídio pBLl apresentou homologia com genes nif K, e nif D e pBL3, com nif D e possivelmentenifH. Os dois fragmentos nif estavam adjacentes ao cromossoma e os re sultados coincidiram com os obtidos por KROL et a $i$ i (1981). 
Estes autores analisaram híbridos nif e propuseram a existên cia de um operon nif HDK em $A$. vinelandii como demonstrado para K. pneumoniae, utilizando as mesmas técnicas.

Grandes plasmídios isolados de 1 inhagens de $R$. Zeguminosarum, R. trifolii e R. phaseoli, hibridizaram com parte dos genes nif de K. pneumoniae, a conträrio de $R$. meZiZoti que não hibridizou.

Com o intuito de se verificar a mobilização e expressão de plasmídios entre diferentes espécies de bacté rias, vārios sistemas de clonagem carregando genes nif foram construídos. Plasmídios Inc P-1 foram transferidos por conjugação para Azotobacter e Azospirizlum e RP4 introduzido por transformação em Azotobacter (Polsinelli et alii, 1980; DAVID et alii, 1981). Em um derivado do plasmídio RK2, designado como pRK290, apresentando resistência à tetraciclina e com um ünico sítio de restrição para EcoRl e BgLII, foi clonado um segmento nif de Azospirizlum. Este plasmídio foi transferido para Azospirizlum, onde se manteve estável (DITTA et alii, 1980).

O plasmídio RSF 1010 e seus derivados puderam ser mobilizados para $E$. coli e outras Gram negativas, incluindo Pseudomonas, Azotobacter, Rhizobium e Azospirizlum (GUER RY et alii, 1974; DAVID et alii, 1981). Um derivadodo RSF 1010, denominado pKT230, foi utilizado para clonarogenenif A 
de Klebsielza, o qual foi posteriormente transferido para $A-$ zotobacter (KENNEDY e ROBSON, 1983).

Plasmídios pRK290, pLAFRl, PKT230 e pSUP106 fo ram utilizados na construção de bancos de genes de Azotobacter e AzospirizZum e armazenados em E. coli (FRIEDMAN et alii, 1982). Os clones obtidos puderam ser analisados por complementação após conjugação com uma série de mutantes de Azotobacter e Azospirizlum.

Os plasmídios pLAFRl e pSUP106 foram üteis na clonagem de genes de $R$. melizoti (FRIEDMAN et alii, 1982). No entanto, um procedimento alternativo foi desenvolvido por DAVID et alii (1981) que transferiram plasmídios de Rhizobium diretamente para Azotobacter. Para isto, se basearam em observações anteriores de PAGE (1977), onde DNA de Rhizobium transformou mutantes $n i f^{-}$de Azotobacter. 


\section{MATERIAL E METODOS}

\subsection{Amostras bacterianas utilizadas}

As 1 inhagens bacterianas utilizadas neste tra balho são de várias procedências (Escola Paulista de Medicina, Centró de Biotecnologia-RGS, Laboratório de Microbiologia do Solo/ESALQ-USP, Seção de Microbiologia/CENA-USP) e no decorrer dos experimentos foram isoladas algumas linhagens do s 010

A descrição dest as linhagens e procedência es tão apresentadas na Tabela 1 . 
TABELA 1 - Características e procedências das linhagens bacterianas utilizadas.

\begin{tabular}{|c|c|c|}
\hline Linhagem & Característica & Procedência \\
\hline $\begin{array}{l}\text { Escherichia coli } \\
\text { K12 }\end{array}$ & $\begin{array}{l}\text { portadora do plasmi- } \\
\text { dio Rldrdl9, com mar } \\
\text { cas de resistência } \\
\text { para estreptomicina, } \\
\text { ampicilina e cloran- } \\
\text { fenicol. }\end{array}$ & $\begin{array}{l}\text { Escola } \\
\text { Paulista de } \\
\text { Medicina }\end{array}$ \\
\hline $\begin{array}{l}\text { Escherichia coli } \\
\text { K12 }\end{array}$ & $\begin{array}{l}\text { portadora do plasmi- } \\
\text { dio Sa, com marcas de } \\
\text { resistência para estre } \\
\text { ptomicina, cloranfeni- } \\
\text { col e canamicina }\end{array}$ & $\begin{array}{l}\text { Escola } \\
\text { Paulista de } \\
\text { Medicina }\end{array}$ \\
\hline $\begin{array}{l}\text { Escherichia coli } \\
\text { K12-HB101 }\end{array}$ & $\begin{array}{l}\text { leu }{ }^{-} \text {pro-, tendo re- } \\
\text { vertido as marcas } \\
\text { lac, Bl e provave } 1- \\
\text { mente recA. Sem me- } \\
\text { canismos de restri- } \\
\text { ça e modificação }\end{array}$ & $\begin{array}{l}\text { Escola } \\
\text { Paulista de } \\
\text { Medicina }\end{array}$ \\
\hline $\begin{array}{l}\text { Escherichia coli } \\
\text { K12-711 }\end{array}$ & $\begin{array}{l}\text { lac } \mathrm{c}^{-} \text {his trip } \mathrm{pro}^{-} \\
\text {fen e resistente ao } \\
\text { acido nalidixico }\end{array}$ & $\begin{array}{l}\text { Escola } \\
\text { Paulista de } \\
\text { Medicina }\end{array}$ \\
\hline $\begin{array}{l}\text { Escherichia coli } \\
\text { K12-c600 }\end{array}$ & $\begin{array}{l}\text { lac } \underline{c}^{-} \text {tim }^{-} \text {treo leu } \\
\mathrm{B}^{-} \text {. Sem mecanismo } \\
\text { de restrição e modifi } \\
\text { cação }\end{array}$ & $\begin{array}{l}\text { Escola } \\
\text { Paulista de } \\
\text { Medicina }\end{array}$ \\
\hline $\begin{array}{l}\text { Escherichia coli } \\
\text { K12- CA77 }\end{array}$ & $\begin{array}{l}\text { lac }{ }^{-} \text {, mutante Hfr } \\
\text { (plasmidio } F \text { inserido } \\
\text { no cromossoma), tendo } \\
\text { revertido a marca } B_{1}\end{array}$ & $\begin{array}{l}\text { Escola } \\
\text { Paulista de } \\
\text { Medicina }\end{array}$ \\
\hline Escherichia coli & portadora do plasmi- & Centro de \\
\hline K12- pсBT01/HB101 & $\begin{array}{l}\text { dio R621a contendo o } \\
\text { Tn5, com marcas de re } \\
\text { sistencia para tetra- } \\
\text { ciclina e canamicina }\end{array}$ & $\begin{array}{l}\text { Biotecnologia } \\
\text { Universidade } \\
\text { Federal - RGS }\end{array}$ \\
\hline $\begin{array}{l}\text { Azospirillum brasi } \\
\text { lense }\end{array}$ & fixadora livre de $\mathrm{N}_{2}$ & $\begin{array}{l}\text { Centro de } \\
\text { Biotecnologia }\end{array}$ \\
\hline sp 7 & & $\begin{array}{l}\text { Universidade } \\
\text { Federal - RGS }\end{array}$ \\
\hline
\end{tabular}


(continuação da Tabela 1)

Linhagem

Característica

Procedência

Azotobacter vineIandi $i$

ATCC 478

Azotobacter vineIandii

$\mathrm{OP}$

Azotobacter chroococcum

$$
\text { i solados } \begin{aligned}
& 80-\text { IV } \\
& 80-2 \text { I I I } \\
& 40-1 \\
& 2-2 \text { I I } \\
& 22-1 \\
& 74-1 \\
& \text { LAMS } \\
& 40-1 \text { IV }
\end{aligned}
$$

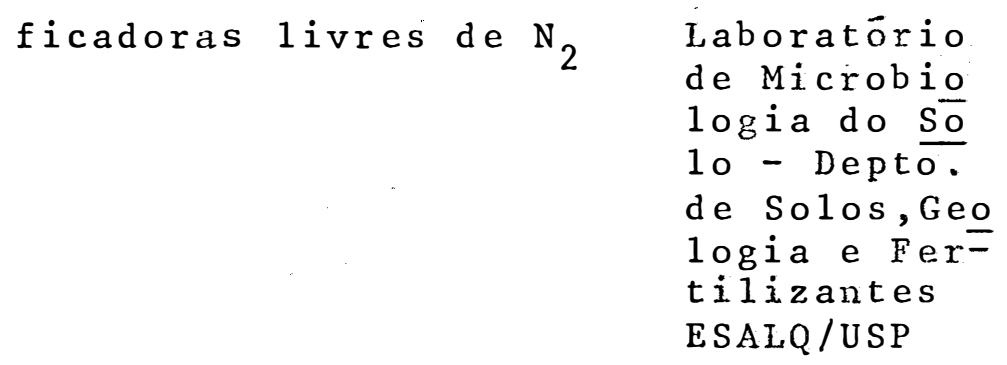

ficadoras livres de $\mathrm{N}_{2} \quad$ Laboratōio de Microbio logia do so 1o - Depto. de Solos, Geo logia e Fer= tilizantes ESALQ / USP

isolados $12 \mathrm{~B}$

$13-2$ $20-\mathrm{AM}$ $5-3$
fixadoras 1 ivres de $\mathrm{N}_{2}$ Seção de Mi- crobiologia do Solo CENA/USP




\subsection{Meios de cultura e soluções}

\subsubsection{Caldo nutriente}

extrato de carne: $3,0 \mathrm{~g}$

peptona: $5,0 \mathrm{~g}$

āgua destilada: $1000 \mathrm{ml}$

3.2.2. Nutriente Agar. (NA)

Ao caldo nutriente, descrito no item anterior, foram acrescentados $15 \mathrm{~g}$ de agar por 1 itro de meio.

3.2.3. Meio mínimo de E. coli. (MMEC)

(SANTOS e AFFONSO, 1982)

$$
\begin{aligned}
& \mathrm{KH}_{2} \mathrm{PO}_{4}: 3,0 \mathrm{~g} \\
& \mathrm{~K}_{2} \mathrm{HPO}_{4}: 7,0 \mathrm{~g} \\
& \left(\mathrm{NH}_{4}\right)_{2} \mathrm{SO}_{4}: 1,0 \mathrm{~g} \\
& \mathrm{MgSO}_{4} \cdot 7 \mathrm{H}_{2} \mathrm{O}: 2,0 \mathrm{~g} \\
& \text { citrato de sódio: } 0,5 \mathrm{~g} \\
& \text { glicose: } 5,0 \mathrm{~g} \\
& \text { agar: } 15,0 \mathrm{~g} \\
& \text { água destilada: } 1000 \mathrm{~m} 1 \\
& \text { o meio foi suplementado com aminoācidos e àci }
\end{aligned}
$$
dos nucleicos $(40 \mu g / m 1)$ ou vitaminas $(10 \mu g / m 1)$ quando necessārio, conforme as deficiências apresentadas pela linhagem utilizada. 
3.2.4. Meiomínimo de E. coli semnitrogênio (MMEC $\mathrm{s} / \mathrm{N}$ )

Este meio foi preparado de modo idêntico ao meio mínimo de $E$. coli (item 3.2.3), mas não foi adicionada a fonte de nitrogênio, $\left(\mathrm{NH}_{4}\right)_{2} \mathrm{SO}_{4}$.

3.2.5. Meio YEPD.

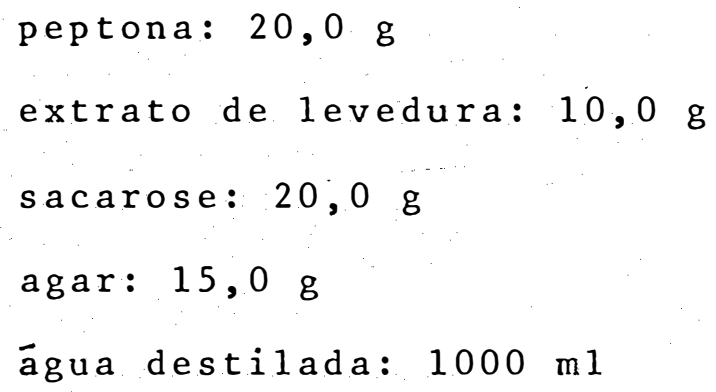

3.2.6. Meio minimo de levedura de WICKERHAM

$$
\begin{aligned}
& \mathrm{KH}_{2} \mathrm{PO}_{4}: 10,0 \mathrm{~g} \\
& \mathrm{MgSO}_{4} \cdot 7 \mathrm{H}_{2} \mathrm{O}: 5,0 \mathrm{~g} \\
& \mathrm{CaCl}_{2} \cdot 2 \mathrm{H}_{2} \mathrm{O}: 1,0 \mathrm{~g} \\
& \mathrm{NaCl}: 1,0 \mathrm{~g} \\
& \left(\mathrm{NH}_{4}\right)_{2} \mathrm{SO}_{4}: 3,0 \mathrm{~g} \\
& \text { glicose }: 20,0 \mathrm{~g} \\
& \text { agar: } 15,0 \mathrm{~g} \\
& \text { ägua destilada: } 1000 \mathrm{ml}
\end{aligned}
$$


3.2.7. Meio mínimo para regeneração de protoplastos. de leveduras.

Ao meio mínimo descrito no item 3.2 .6 , foiacrescentado sorbitol, na concentração final de $1 \mathrm{M}$.

3.2.8. Agar manitol (NORRIS e RIBBONS, 1970)

$\mathrm{K}_{2} \mathrm{HPO}_{4}: 10,0 \mathrm{~g}$

$\mathrm{MgSO}_{4} \cdot 7 \mathrm{H}_{2} \mathrm{O}: 0,5 \mathrm{~g}$

manitol: $10,0 \mathrm{~g}$

$\mathrm{Na}_{2} \mathrm{MoO}_{4}: 0,002 \mathrm{~g}$

$\mathrm{FeCl}_{3}: 0,02 \mathrm{~g}$

agar: $15,0 \mathrm{~g}$

água destilada: $1000 \mathrm{~m} 1$

$\mathrm{pH}: 7,4$

3.2.9. Meio LG (BECKING, 1962 )

$\mathrm{K}_{2} \mathrm{HPO}_{4}: 1,0 \mathrm{~g}$

$\mathrm{CaCl}_{2}: 0,02 \mathrm{~g}$

$\mathrm{MgSO}_{4} \cdot 7 \mathrm{H}_{2} \mathrm{O}: 0,2 \mathrm{~g}$

$\mathrm{Na}_{2} \mathrm{MoO}_{4}: 0,002 \mathrm{~g}$

$\mathrm{FeCl}_{3}: 0,02 \mathrm{~g}$

sacarose: $20,0 \mathrm{~g}$

$\mathrm{CaCO}_{3}: 2,0 \mathrm{~g}$

sol. alcoólica de bromotimol 0,5\%: $2,5 \mathrm{~m} 1$ 
agar: $15,0 \mathrm{~g}$

ägua destilada: $1000 \mathrm{~m} 1$

$\mathrm{pH}: 7,5$

\subsubsection{Meio LGN}

Ao meio LG, descrito no item anterior, foi a crescentado $1,0 \mathrm{~g}$ de $\left(\mathrm{NH}_{4}\right) \mathrm{SO}_{4}$ por 1 itro de meio.

3.2.11. Meio de Burk (STRANDBERG e WILSON, 1967)

$\mathrm{K}_{2} \mathrm{HPO}_{4}: 0,8 \mathrm{~g}$

$\mathrm{KH}_{2} \mathrm{PO}_{4}: 0,2 \mathrm{~g}$

$\mathrm{MgSO}_{4} \cdot 7 \mathrm{H}_{2} \mathrm{O}: 0,2 \mathrm{~g}$

$\mathrm{CaCl}_{2} \cdot 2 \mathrm{H}_{2} \mathrm{O}: 0,09 \mathrm{~g}$

$\mathrm{FeSO}_{4}: 0,03 \mathrm{~g}$

$\mathrm{Na}_{2} \mathrm{MOO}_{4}: 0,02 \mathrm{~g}$

glicose: $20,0 \mathrm{~g}$

água destilada: $1000 \mathrm{~m} 1$

$\mathrm{pH}: \quad 7,5$

3.2.12. Meio para indução de competência (oFe + N)

(PAGE, 1982)

Ao meio Burk (item 3.2.11) foram adicionados $40 \mathrm{\mu g} / \mathrm{ml}$ de $\left(\mathrm{NH}_{4}\right)_{2} \mathrm{SO}_{4}$ e o sulfato ferroso (FeSO 4 ) e cloreto de cálcio não foram adicionados. 
3.2.13. Meio para Beijerinckia (LGB) (BECKING, 1962)

$\mathrm{K}_{2} \mathrm{HPO}_{4}: 0,8 \mathrm{~g}$

$\mathrm{KH}_{2} \mathrm{PO}_{4}: 0,2 \mathrm{~g}$

$\mathrm{MgSO}_{4} \cdot 7 \mathrm{H}_{2} \mathrm{O}: 0,5 \mathrm{~g}$

$\mathrm{FeCl}_{3}: 0,025 \mathrm{~g}$

$\mathrm{MnSO}_{4}: 0,002 \mathrm{~g}$

$\mathrm{ZnSO}_{4}: 0,005 \mathrm{~g}$

$\mathrm{CuSO}_{4}: 0,004 \mathrm{~g}$

g1icose: $20,0 \mathrm{~g}$

agar: $15,0 \mathrm{~g}$

àgua destilada: $1000 \mathrm{~m} 1$

$\mathrm{pH}: 6,4$

3.2.14. Meio minimo de DAVIS modificado (LEMOS, 1980)

$$
\begin{aligned}
& \mathrm{KH}_{2} \mathrm{PO}_{4}: 0,3 \mathrm{~g} \\
& \mathrm{~K}_{2} \mathrm{HPO}_{4}: 0,7 \mathrm{~g} \\
& \mathrm{MgSO}_{4} \cdot 7 \mathrm{H}_{2} \mathrm{O}: 0,01 \mathrm{~g} \\
& \text { citrato de södio: } 0,05 \mathrm{~g} \\
& \text { succinato de sódio: } 0,1 \mathrm{~g} \\
& \text { agar: } 15,0 \mathrm{~g} \\
& \text { água destilada: } 1000 \mathrm{~m} 1 \\
& \text { pH: } 7,0
\end{aligned}
$$


3.2.15. T ampão TEB

tris $-\mathrm{OH}: 10,8 \mathrm{~g}$

$\mathrm{Na}_{2}$ EDTA: $0,93 \cdot \mathrm{g}$

$\mathrm{H}_{3} \mathrm{BO}_{3}: 5,5 \mathrm{~g}$

água desmineralizada: $1000 \mathrm{ml}$

$\mathrm{pH}: \quad 8,2$

3.2.16. Tampão E (tris-acetato)

tris $-\mathrm{OH}: 4,8 \mathrm{~g}$

$\mathrm{Na}_{2}$ EDTA: $0,75 \mathrm{~g}$

àgua desminera1izada: $1000 \mathrm{~m} 1$

$\mathrm{pH}: \quad 8,0$

3.2.17. Tampão de amostra.

azul de bromofenol: 0,05 $\mathrm{g}$

Ficol1: $3,0 \mathrm{~g}$

tampão tris-acetato (item 3.2.16): 20,0 m1

3.2.18. Tampão S SC

$\mathrm{NaCl}: 8,7 \mathrm{~g}$

citrato de sódio: $0,015 \mathrm{M}$

água desmineralizada: $1000 \mathrm{ml}$ 
3.2.19. Tampão sorbitol-fosfato (TSP)

solução A $\left(0,2 \mathrm{M} \mathrm{Na}{ }_{2} \mathrm{HPO}_{4}\right): 217,5 \mathrm{ml}$

solução B $\left(0,2 \mathrm{M} \mathrm{NaH} 2 \mathrm{PO}_{4}\right): 32,5 \mathrm{ml}$

sorbitol: $1 \mathrm{M}$

àgua destilada: $500 \mathrm{~m} 1$

3.2.20. Tampão Burk

Ao meio Burk (item 3.2.11) sem sacarose, adicionou-se $1,0 \mathrm{~g}$ de $\left(\mathrm{NH}_{4}\right)_{2} \mathrm{SO}_{4}$ e o pH foi ajustado para 7,0, com solução de HCl $0,1 \mathrm{~N}$.

\subsubsection{Mistura 1itica.}

Ficol1: $10,0 \mathrm{~g}$

$\mathrm{Na}_{2}$ EDTA: $0,19 \mathrm{~g}$

1 isozima: $25 \mathrm{mg}$

azul de bromofenol: $2,5 \mathrm{mg}$

sol. RNAse (em tampão acetato de sódio): $50 \mu 1$

TEB (item 3.2.15): $50 \mathrm{ml}$

3.2.22. Solução de SDS - Ficol1 10\%,

SDS: $0,2 \mathrm{~g}$

Ficol1: $10,0 \mathrm{~g}$

TEB (item 3.2.15): $100 \mathrm{ml}$ 
3.2.23. Solução de SDS-Ficoll $5 \%$

SDS : $0,2 \mathrm{~g}$

Ficol1: 5,0 g

TEB (item 3.2.15): $100 \mathrm{~m} 1$

3.2.24. Solução detergente

SDS $: 3,0 \mathrm{~g}$

$\mathrm{Na}_{2}$ EDTA: $3,7 \mathrm{~g}$

sol. Tris $40 \mathrm{mM}: 100 \mathrm{ml}$

O pH foi ajustado para $12,6 \mathrm{com} \mathrm{NaOH} 8 \mathrm{~N}$ e a so luçãofiltrada em filtro Milipore $(0,45 \mu \mathrm{m})$.

3.2.25. Solução tris-HC1 2M

tris: $4,8 \mathrm{~g}$

água destilada: $200 \mathrm{~m} 1$

$\mathrm{pH}: 6,0$, ajustado com HCl $1 \mathrm{~N}$

3.2.26. Solução tris-HC1 $0,05 \mathrm{M}$

tris: $3,0 \mathrm{~g}$

água destilada: $500 \mathrm{~m} 1$

$\mathrm{pH}: 8,0$, ajustado $\operatorname{com} \mathrm{HC}^{1} 0,1 \mathrm{~N}$ 
3.2.27. Solução acetato $\mathrm{pH} 4,4$

solução A: 1,2 m l de ácido acético

$100 \mathrm{ml}$ de àgua destilada

solução B: $1,64 \mathrm{~g}$ de acetato de sódio

$100 \mathrm{~m} 1$ de ägua destilada

Na preparação de $25 \mathrm{~m} 1$ de solução acetato foram misturados $12,75 \mathrm{~m} 1$ da solução A com $12,25 \mathrm{~m} 1$ da solução B.

\subsubsection{Antibióticos.}

Foram utilizados os antibióticos ampicilina (Bayer), tetraciclina (Bristol), cloranfenicol (Carlo Erba)e canamicina (Bristol). As soluções, cujas concentraçöes variaram de acordo com o experimento, foram preparadas momentos antes do seu uso e adicionadas ao meio de cultura após a autoclavagem, quando o meio se encontrava a uma temperatura em torno de $45^{\circ} \mathrm{C}$.

\subsubsection{Solução de purinas e pirimidinas.}

Foram preparadas soluções individuais contendo bases nitrogenadas (adenina, citosina, timina, guanina e uracila) nas concentrações de $100 \mu \mathrm{g} / \mathrm{m} 1$. 


\subsubsection{Solução de vitaminas}

Foram também preparadas soluções individuais de vitaminas (ácido fólico, biotina, pantotenato de cálcio, inositol, nicotinamida, äcido paraminobenzóico, piridoxina,tiamina e riboflavina) nas concentrações de $100 \mu \mathrm{g} / \mathrm{ml}$.

\subsubsection{Solução de aminoácidos}

Soluções de cada um dos seguintes aminoácidos foram preparadas (prolina, arginina, lisina, triptofano, metionina, histidina, isoleucina, glutamina, homoserina, treonina, cistina) nas concentrações de $100 \mu \mathrm{g} / \mathrm{ml}$.

\subsection{Isolamento de bactérias assimbióticas do solo fixa- doras de nitrogênio}

Além das linhagens bacterianas fixadoras de ni trogênio cedidas por vários laboratórios (item 3.1), isolouse outras a partir de amostras de solos. Para isto, foram utilizados solos de várias procedências (Piracicaba, Botucatu e são (arlos) com características físico-químicas diferen tes. Nesta seleção, utilizou-se os métodos propostos por THo MAS (1960) e NORRIS e RIBBONS (1970), que consiste no enriquecimento do solo com meio de cultura líquido isento de ni- 
trogênio incorporado (meios LG, Davis, Manitol e Burk); a mis tura assim preparada, foi colocada diretamente em placade Pe tri e as colônias bacterianas obtidas dessa forma, foram purificadas nos meios correspondentes, na forma sólida.

3.4. Verificação da ocorrência de plasmídios das bactérias. fixadoras de nitrogênio

Dois métodos de eletroforese em gel de agarose foram utilizados para verificação da ocorrência de plasmí dios em bactérias.

3.4.1. 19 método (SANTOS e AFFONSO, 1982)

As amostras bacterianas foram semeadas por 48 horas a $30^{\circ} \mathrm{C}$ em meios de cultura isentos de nitrogênio, de a cordo com suas exigências. As 1 inhagens de $E$. coli com plas mídios de peso molecular conhecido, que serviram como padrões foram crescidas em caldo nutriente por 24 horas a $37^{\circ} \mathrm{C}$. seguir, as células foram centrifugadas e lavadas duas vezes em tampão TEB. Após terem sido ressuspensas em $100 \mu 1$ de tam pão TEB, foram acrescentados $30 \mu 1$ da mistura 1 itica; $50 \mu 1$ fo ram transferidos para a canaleta do gel (agarose 0,8\% em tampão TEB). A lise foi realizada na canaleta com a adição de $30 \mu 1$ de solução SDS-Ficol1 10\%; após a mistura das duas 
camadas com um palito, foram acrescentados $100 \mu 1$ de solução SDS - Ficol1 $5 \%$.

As canaletas das placas de gel foram seladas com agarose e o tampão TEB foi usado para preencher os compartimentos do aparelho para eletroforese vertical. Fez-se uma corrida inicial de 45 minutos com uma corrente elétrica de $2 \mathrm{~mA}$ e a seguir foi alterada para $45 \mathrm{~mA}$. A corridafoi in terrompida quando o corante chegou ao outro extremo da placa. Terminada a migração, fez-se a coloração do gel com brometo de etidio ( $1 \mu \mathrm{g} / \mathrm{ml}$ em TEB) por 30 minutos e a observação das bandas no gel foi feita em lâmpada ultra-violetade ondas cur tas.

\subsubsection{2o método (KADO e LIU, 1981, modificado)}

O crescimento das células bacterianas foi fei to de modo idêntico ao método anterior (3.4.1). Após a centrifugação e lavagem por duas vezes em tampao E, as células foram ressuspensas no mesmo tampão, acrescido de $15 \mu \mathrm{g} / \mathrm{ml}$ de RNAse.

Foram transferidos $50 \mu 1$ dessa mistura sobre $300 \mu 1$ de solução detergente previamente colocada em um tubo. Após uma agitação suave, a mistura foi colocada a $60^{\circ} \mathrm{C}$ por 30 minutos e, em seguida, resfriada, sendo adicionados $20 \mu 1$ de tris-HC1 $0,05 \mathrm{M}$ e $0,5 \mathrm{~m} 1$ de uma solução fenol-cloro- 
fórmio 1:1. Em seguida, fez-se a centrifugação e coletou-se $50 \mu 1$ da fase aquosa, adicionando-se $10 \mu 1$ do tampão de amos tra, sendo a mistura transferida para a canaleta do ge 1 de garose $(0,8 \%$ em tampão E).

As câmaras da cuba de eletroforese foram preenchidas com tampão $E$ as etapas seguintes foram semelhantes às utilizadas no primeiro método citado.

\subsection{Amplificação de plasmídios}

Linhagens fixadoras de $\mathrm{N}_{2}$ foram desenvolvidas em meio contendo nitrogênio incorporado, acrescido de $50 \mu g$ de caseina hidro1. até o final da fase exponencial de crescimento. A incubação foi a $30^{\circ} \mathrm{C}$ por 72 horas; a seguir, foi acrescentada $0,5 \mathrm{~m} 1$ de solução de cloranfenicol ( $50 \mathrm{mg} / \mathrm{m} 1)$, deixando-senesta condição por 20 horas. Após este tratamen to, as células foram analisadas para ocorrência de plasmídios (item 3.4).

3.6. Estimativa dos pesos moleculares dos plasmídios de linhagens fixadoras de $\mathrm{N}_{2}$

$\mathrm{Na}$ estimativa dos pesos moleculares dos plas- 
mídios das amostras bacterianas, utilizou-se o método propos to por MEYERS et alii (1976). Este se baseia na comparação da migração em eletroforese em gel de agarose dos plasmídios em estudo, com a migração de plasmídios de pesos moleculares já conhecidos. As linhagens padrões utilizadas foram as de E. coli com os plasmídios R1drd19, Sa e p307.

3.7. Eliminação de plasmídios das linhagens fixadoras de $\underline{N}_{2}$

As 1 inhagens que comprovadamente mostraram a presença de plasmídios (através da técnica de eletroforese, í tem 3.4), foram submetidas aos tratamentos com agentes de "cura", com a finalidade de se eliminar esses plasmídios. Pa ra isso, utilizou-se dos métodos descritos a seguir e a porcentagem de eliminação foi calculada como o número de colôni as, que eliminaram o plasmídio, em relação ao total decolôni as submetidas ao tratamento. Nos casos onde se conseguiu esse intento, as células foram posteriormente ensaiadas para a verificação de uma possível alteração no processo de fixação de $\mathrm{N}_{2}$, pela verificação do seu crescimento em meio sem ni trogênio incorporado. 


\subsubsection{Tratamento com brometo de etidio, acridinala-} $\underline{\text { ranja e acriflavina }}$

Culturas de linhagens portadoras de plasmídio foram semeadas em frascos contendo meio líquido com concentrações variando de 2 a $50 \mu \mathrm{g} / \mathrm{ml}$ de brometo de etidio, acridina orange ou acriflavina. Após 24 horas de incubação sob agitação, foram selecionadas as culturas que se desenvolveram em concentrações sub inibitórias dos agentes citados. Es tas foram diluidas convenientemente e semeadas em placas con tendo o meio de cultura propício para cada linhagem, acresci do da fonte de nitrogênio, incubando-se a $30^{\circ} \mathrm{C}$ por 48 horas.

A seguir, as colônias foram ensaiadas para se verificar a possível presença de segregantes nif ${ }^{-}$(incapazes de tixar $\mathrm{N}_{2}$ ) e para isso se utilizou da técnica dá réplica em veludo (LEDERBERG e LEDERBERG, 1952) para meios com e sem nitrogênio incorporado. A comprovação da perda dos plasmí dios foi feita através da eletroforese em gel de agarose.

\subsubsection{Tratamento pelocalor}

Neste procedimento, culturas de linhagens portadoras de plasmídio, foram semeadas em meio líquido e incubadas a $42-44^{\circ} \mathrm{C}$, sem agitação. Decorridas 24 horas, estas foram diluidas e semeadas em meio sólido, seguindo-se o mesmo roteiro já descrito no item 3.7.1 para a seleção de segre 
gantes $n i f^{-}$.

\subsection{Identificação taxonômica do isolado bacteriano 9}

A fim de se proceder posteriormente um estudo genético do isolado 9 (item 3.3), uma bactéria fixadora de $\mathrm{N}_{2}$ assimbiótica não portadora de plasmídio, fez-se inicialmente a identificação quanto ao gênero e espécie. Paraisto, foram seguidos os critérios de classificação citados por BECKING (1962), DOBEREINER (1966) e BREED et alii (1974).

3.9. Determinação do nível de resistência do isolado 9 a antibióticos

Foram preparadas placas de Petri contendo o meio LGN mais um dos antibióticos ampicilina, tetraciclina, cloranfenicol ou canamicina em concentrações variando de 0 a $200 \mu g / m 1$. Em cada uma destas placas, foi semeada uma a $1 \dot{i}-$ quota da cultura bacteriana do isolado 9 , desenvolvida a $30^{\circ} \mathrm{C}$ por 24 horas em LGN 1 íquido.

Após a incubação das placas por 72 horas a 30

${ }^{\circ} \mathrm{C}$, foi observado o crescimento e considerou-se como níve 1 de resistência a concentração da droga imediatamente inferior àquela que impedia o crescimento da cultura bacteriana. A 
viabilidade das cēlulas foi observada inoculando-se no mesmo meio, isento da droga.

\subsection{Curva de sobrevivência do isolado 9 à radiação.} $\underline{\text { ultra-violeta }}$

Uma cultura de células desenvolvida a $30^{\circ} \mathrm{C}$ por 72 horas em $10 \mathrm{~m} 1$ de LGN 1 Íquido foi centrifugada a $12000 \mathrm{~g}$ durante 10 minutos. O sobrenadante foi desprezado e as célu las foram suspensas em soluçãosalina. A seguir, fez-se a irradiação com luz ultra-violeta durante $30,60,90,150,240$ e 300 segundos e após cada tempo de exposição, semeou-se em. placas contendo meio LGN, incubando-se por 72 horas a $30^{\circ} \mathrm{C}$. Posteriormente, as colônias foram contadas e comparadas com o número de colônias não submetidas à irradiação (controle).

3.11. Curva de sobrevivência do isolado 9 ao tratamento com äcido nitroso.

Uma cultura de cēlulas desenvolvida a $30^{\circ} \mathrm{C}$ por 72 horas em $10 \mathrm{ml}$ de LGN, foi centrifugada a $12000 \mathrm{~g}$ por 10 minutos. 0 sobrenadante foi desprezado e as células foram suspensas em solução salina. A seguir, semeou-se $0,5 \mathrm{~m} 1$ des sa suspensão de células em tubos contendo $0,33 \mathrm{~m} 1$ de solução 
nitrito de sódio $0,5 \mathrm{M}$ e $9,17 \mathrm{~m} 1$ da solução acetato pH 4,4, seguindo-se a incubação a $30^{\circ} \mathrm{C}$. Amostras de células destes tubos foram retiradas após $4,8,12,16$ e 20 minutos e semea das em placas contendo LGN, incubando-se por 72 horas a $30^{\circ} \mathrm{C}$. Posteriormente, as colônias foram contadas e comparadas com o número de células do controle, sem tratamento.

3.12. Obtenção de mutantes $n i f^{-}$no isolado 9 , através da irradiação com luz ultra-violeta e tratamento com $\underline{\text { àcido nitroso }}$

Como no item anterior, uma suspensão de células foi centrifugada, o sobrenadante foi desprezado e a seguir, irradiada com 1 uz ultra-violeta por 2 minutos ou trata da com ácido nitroso por 8 minutos. Após esse tempo de expo sição, semeou-se alíquotas de células diluidas convenientemente, em placas contendo meio LGN.

As colonias que cresceram nestas condições fo ram replicadas para placas com LG e LGN. Após a confirmação da mutação, foram selecionadas células $n i f^{-}$.

\subsection{Auxanografia dos mutantes nif-}

os mutantes $n i f^{-}$obtidos no item 3.12 , foram 
ensaiados quando à ocorrencia de uma mutação auxotrófica. Assim, estes foram inoculados em LGN líquido e semeados em pla cas contendo: $L G$ + solução de aminoācidos, LG + soluçãodevi taminas e LG + solução de äcidos nucleicos.

Após a incubação a $30^{\circ} \mathrm{C}$ por 48 horas, observou-se o crescimento, comparando-se com o meio LG sem os requerimentos. Nos casos onde houve crescimento de colônias apenas no meio LG suplementado, estas foram confirmadas para auxotrofia para cada um dos componentes individualmente, da solução em questão.

\subsection{Isolamento de mutantes resistentes a antibióticos}

As 1 inhagens mutantes $\operatorname{nif}^{-}$e o isolado 9 foram ensaiadas com o objetivo de se selecionar células resistentes a drogas, a serem utilizadas em experimentos posterio res. Para isto: foram observados os dados obtidos do experi mento descrito no item 3.9 sobre o nível de resistência do solado 9, em relação a antibióticos.

Inicialmente foram desenvolvidas culturas bac terianas em meio LGN 1 íquido por 48 horas a $30^{\circ} \mathrm{C}$, das quais se transferiu uma aliquota para placas contendo LG ou LGN + $2 \mu g / m 1$ de tetraciclina. 0 mesmo procedimento foi seguido para os, outros antibióticos, excetuando-se as concentrações 
empregadas que foram 5,20 e $50 \mu g / m 1$ de canamicina, cloranfenicol e ampicilina, respectivamente. Após a incubação de 72 horas a $30^{\circ} \mathrm{C}$, isolou-se as colônias que se desenvolveram nessas condições.

\subsection{Extração de DNA total do isolado 9 e mutantes nif}

Foram extraídos o DNA de culturas de células de mutantes nif $f^{-}$e isolado 9 resistentes a ampicilina e isolado 9 selvagem. Desta. forma, as amostras foram desenvolvidas em $100 \mathrm{~m} 1 \mathrm{de}$ LGN e centrifugadas a $12000 \mathrm{~g}$ por $15 \mathrm{minu}$ tos. As células foram suspensas em $5 \mathrm{ml}$ de $\operatorname{tris-HC1} 0,05 \mathrm{M}$ $(\mathrm{pH} 8,0)$, centrifugadas novamente, sendo ressuspensas em $8 \mathrm{~m} 1$ de sacarose 25\% (em tris-HC1 0,05M) contendo 1 isozima ( $10 \mathrm{mg} /$ m1) e mais $2 \mathrm{ml}$ de EDTA 0,5M pH 8,2 (em tris-HC1 0,05M).

Fez-se uma incubação por 10 minutos a $25^{\circ} \mathrm{C}$ e acrescentou-se $1 \mathrm{~m} 1$ de SDS $10 \%$, deixando-se durante $30 \mathrm{minu}-$ tos a $60^{\circ} \mathrm{C}$. A seguir, foi adicionada uma solução clorofórmio-álcool isoamỉlico (24:1), em um volume igual aovolume to tal do tubo, agitando-se lentamente até a formação de emulsão homogênea. Centrifugou-se a 14000.g por 20 minutos e transferiu-se a fase aquosa superior para outro tubo, onde se adicionou 2 volumes de etanol gelado $\left(\simeq-5^{\circ} \mathrm{C}\right)$. Após a centri fugação (5000 rpm - 10 minutos), fez-se a secagem à vácuo do älcool remanescente e adicionou-se $1 \mathrm{ml}$ de tampão SSC; se- 
guindo-se a dissolução dos ácidos nucleicos, foi colocada so 1 ução de RNAse até atingir a concentração de $50 \mu g / m 1$. A seguir, foram repetidos os passos descritos após a colocação da solução clorofórmio-isoamilico, finalizando-se com a dissolu ção do DNA em tampão SSC. A determinação da concentração de DNA obtida, foi feita em espectrofotômetro Beckman modelo DB, em $260 \mathrm{~nm}$.

3.16. Experimentos de transformação utilizando o DNA do isolado 9 e dos mutantes nif $^{-}$

Foram realizados quatro experimentos de transformação descritos a seguir, utilizando-se como linhagens re ceptoras os mutantes $n i f^{-}$da 1 inhagem 9, 1 inhagens de $E$. coli (C600, HB101, 711, CA77, Sa) e levedura Saccharomyces cerevi siae (X 2180 - Yeast Stock Center - Universidade da Califórnia, Berkeley).

3.16.1. Transformação interespecífica entre mutantes $n i f^{-}$e DNA do isolado 9. (PAGE, 1982, modificado)

Os mutantes $n i f^{-}$foram crescidos em meio para indução de competência $(\mathrm{OFe}+\mathrm{N})$ por 24 horas a $30^{\circ} \mathrm{C}$. Cerca de $50 \mu 1$ de células competentes $\left(2 \times 10^{7}\right.$ células/m1) foram colocadas em $0,3 \mathrm{~m} 1$ de tampão Burk e acrescentou-se 2,0 $\mu \mathrm{g}$ de 
DNA da 1 inhagem 9. Após 2 horas de incubação a $30^{\circ} \mathrm{C}$, a mistura foi semeada nos meios Burk e LGN com e sem o acréscimo de $50 \mu 1 / m 1$ de ampicilina, incubando-se por 72 horas a $30^{\circ} \mathrm{C}$.

A frequência de transformação foi calculada como o nümero de transformantes nif em relação ao número total de células receptoras utilizadas. o DNAfoi ensaiado para se verificar a esterilidade em meio Burk e cada uma das linhagens mutantes nif ${ }^{-}$também foi ensaiada a fim de se observar possível reversão.

\subsubsection{Transformação entre mutantes $n i f^{-}$}

os mutantes $n i f^{-} 1$ a $n i f^{-} 5$ foram crescidosem meio para indução de competência por 24 horas a $30^{\circ} \mathrm{C}$, e as células foram preparadas conforme descrito no item 3.16.1. Pa ra cada uma das culturas $n i f^{-}$, foram feitos ensaios envolven do sua transformação com o DNA isolado de cada um dos mutantes nif e resistentes a ampicilina. A seleção dos transfor mantes foi feita nos meios Burk e LGN com e sem acréscimo de $50 \mu \mathrm{g} / \mathrm{ml}$ de ampicilina. A frequência de transformação foi calculada em função do número de células receptoras utilizadas, conforme descrito no item 3.16.1. 
3.16.3. Transformação intergenérica entre linhagens de E. coli e DNA do isolado 9

(MANDEL e HIGA, 1970, modificado)

As 1 inhagens receptoras de $E$. coli C 600 , $\mathrm{HB}$ 101, 711, CA77 e Sa, foram crescidas em caldo nutriente por 20 horas a $37^{\circ} \mathrm{C}$, com agitação. Cada uma das culturas foi di luida e alíquotas destas suspensões foram inoculadas em $40 \mathrm{~m} 1$ do mesmo meio, seguindo-se incubação por 3 horas a $37^{\circ} \mathrm{C}$ sob agitação.

Para obtenção de competência, as células foram centrifugadas e lavadas com solução de $\mathrm{CaCl}_{2} 50 \mathrm{mM}$; após isto, foram mantidas a $0^{\circ} \mathrm{C}$ por 25 minutos, sendo este procedimento repetido duas vezes. A $0,2 \mathrm{ml}$ de cada uma das suspensões de células competentes ( $10^{7}$ celulas/m1), adicionouse $3,0 \mu g$ de DNA da 1 inhagem 9 , sendo a mistura mantida a $0^{\circ} \mathrm{C}$ durante 40 minutos. Decorrido este tempo, colocou-se a $42{ }^{\circ} \mathrm{C}$ por 10 minutos, adicionando-se em seguida igual volume de cal do nutriente, e a incubação foi por 20 minutos a $37^{\circ} \mathrm{C}$ sob agitação.

Os transformantes foram selecionados em meio minimo de $E$. coli sem nitrogênio incorporado (MMEC s/N), mass os requerimentos exigidos para cada linhagem $(30 \mu g / m 1$ para aminoácidos e $10 \mu \mathrm{g} / \mathrm{m} 1$ para vitaminas e ácidos nucleicos). A incubação foi a $37^{\circ} \mathrm{C}$ por 72 horas, na presença de $\mathrm{O}_{2}$, bem co 
mo em atmosfera 1 ivre de $0_{2}$ (adição de $0,8 \%$ agar em cobertura).

Como parte da deteç̧ão de transformantes, ain da foram realizados testes para verificaça da atividade da nitrogenase e comparação do crescimento entre estes e a 1 inha gem original doadora do DNA.

\subsubsection{Transformação intergenérica entre S. cerevisiae.}

e DNA do isolado 9 (ECHEVERRIGARAY, 1983)

A 1 inhagem de levedura Y2180 foi crescida por 12 horas a $30^{\circ} \mathrm{C}$ em $100 \mathrm{~m} 1$ de meio YEPD, sendo a seguir subme tida a um tratamento, a fim de se obter protoplastos. Neste tratamento, as células foram inicialmente centrifugadas e $1 \underline{a}$ vadas duas vezes com EDTA $10 \mathrm{mM}$. Após a adição de 2-mercaptoetanol até a concentração de $1 \%$, fez-se a suspensão das cé lulas em TSP 1M. Adicionou-se $1 \mathrm{ml}$ de solução de helicase $4 \%$ e manteve-se a $35^{\circ} \mathrm{C}$, agitando-se em intervalos constantes durante uma hora. A obtenção dos protoplastos foi observada microscopicamente até atingir $90-100 \%$ das células e então a suspensão foi centrifugada e lavada três vezes em TSP.

Para a transformação, foi adicionado $10 \mu 1$ de solução $\mathrm{CaCl}_{2} 1,2 \mathrm{M}$ aos protoplastos e a seguir cerca de $50 \mu 1$ de DNA do isolado 9 para $0,1 \mathrm{ml}$ da suspensão de protoplastos. Após a incubação por 30 minutos a $30^{\circ} \mathrm{C}$, foi adicionado $1 \mathrm{~m} 1$ de PEG 60\% (em TSP), mais solução de $\mathrm{CaCl}_{2}$ até atingiracon- 
centração de $10 \mathrm{mM}$. Agitou-se lentamente e manteve-se por 60 minutos a $30^{\circ} \mathrm{C}$ e a seguir por 5 minutos a $42^{\circ} \mathrm{C}$. Após a 1 ava gem dos protoplastos com tampão TSP, foi feita a semeadura em 'meio mínimo de levedura, isento de fontedenitrogênio acrescido de sorbitol ( $1 M$ ). Adicionou-se uma camada de meio de cobertura contendo $0,8 \%$ de agar, como suporte físico para a regeneração dos protoplastos. o controle foi feito emmeio YEPD com sorbitol (IM).

\subsection{Atividade da nitrogenase.}

A atividade da nitrogenase foi avaliada pela sua capacidade de reduzir acetileno a etileno

(DILWORTH, 1966), detectado em cromatógrafo a gàs.

Este ensaio foi realizado para os transforman tes de $E$. coli e linhagem original (isolado 9). Para isto, utilizou-se culturas de cada uma das amostras crescidasem LG semi-sōlido $(0,2 \%$ agar $)$ por 48 horas a $30^{\circ} \mathrm{C}$. Os frascos foram hermeticamente fechados com tampas de borracha, retirados $3 \mathrm{ml}$ de ar e injetado o mesmo volume de acetileno. Após 2 e 24 horas de incubação a $37^{\circ} \mathrm{C}$, retirou-se $0,5 \mathrm{~m} 1$ do volume da mistura gasosa de cada frasco e fez-se a anäliseno cro matógrafo Beckman GC, modelo 65, do Laboratório de Microbi ologia - CENA/USP. 
Pela análise gráfica dos picos de etileno foi calculada a atividade da nitrogenase presente em cada amos$\operatorname{tra}($ SAITO, 1978$)$.

3.18. Comparação do crescimento entre transformantes nif de $E$. coli e isolado 9

Foram comparados o crescimento dos transformantes de E. coli e isolado 9 em meio com e sem nitrogênio incorporado. Culturas de cada uma das amostras desenvolvidas por 24 horas em caldo nutriente ou Burk, foram diluidas convenientemente e inoculadas em uma série de tubos contendo meio Burk come sem nitrogênio e nutriente líquido. A incubação foi a 37 e $30^{\circ} \mathrm{C}$, respectivamente para as linhagens transformantes e 9 .

As amostras foram retiradas periodicamente, feitas a leitura da densidade ótica em espectrofotômetro Beckman a $620 \mathrm{~nm}$, e com esses dados foram construídas as curvas de crescimento.

\subsection{Experimentos de conjugaçao}

Foram realizados vários experimentos de conju gação entre os transformantes $n i f^{+}$e linhagens doadoras de 
E. coli.

\subsubsection{Conjugação entre transformantes $n i f^{+}$com 1i- nhagens portadoras de plasmídio e Hfr de $E$. coli}

As 1 inhagens doadoras (Sa, R1drd19 e CA77 amp ${ }^{R}$ ) e receptoras (transformantes $n i f^{+}$de $E$. coli) foram crescidas em caldo nutriente por 20 horas a $37^{\circ} \mathrm{C}$. Após esta incubação, as culturas doadoras foram diluidas 100 vezes em caldo nutriente e incubadas por 4 horas a $37^{\circ} \mathrm{C}$, sob agitação.

A seguir, fez-se a mistura na proporçao de 3:1 da cultura doadora em fase exponencial e cultura receptora em fase estacionäria, incubando-se por 3 horas a $37^{\circ} \mathrm{C}$. Decorridoesse tempo, a mistura foi agitada vigorosamente, diluida e semeada nos meios: MMEC s/N + cloranfenicol e ampici lina, MMEC s/N + cloranfenicol e canamicina, MMEC s/N + ampi cilina, para as misturas cujas doadoras foram respectivamente as linhagens Rldrd19, Sa e CA77. Os antibióticos foram a crescentados ao meio na concentração de $20 \mu \mathrm{g} / \mathrm{ml}$. A incubação foi a $37^{\circ} \mathrm{C}$ durante 72 horas, quando então foram selecionadas colônias $n i f^{+}$e resistentes a drogas. 
3.19.2. Conjugação entre transformantes portadores de. plasmídio e linhagens receptoras de E. coli.

os recombinantes obtidos no item 3.19 .1 foram conjugados com linhagens $F^{-}$de $E$. coli (C600 e 711), a fim de se verificar a possibilidade dos genes nif estarem nestes plasmídios. o procedimento de conjugação foi o mesmo descri to no item anterior.

Após a conjugação, a mistura de cêlulas foi di luida convenientemente e semeada em NA + cloranfenicol e ampicilina e MMEC mais estes mesmos antibióticos. A incubação foi feita por 48 horas a $37^{\circ} \mathrm{C}$ e selecionou-se as colônias que apresentaram as mesmas características das células receptoras e resistência aos antibióticos. Isto foi verificado pela comparação destes nos dois meios de cultura. Posteriormente estas colônias foram replicadas para MMEC s/N acrescido dos mesmos antibióticos, além dos requerimentos exigidos pela linhagem receptora. A incubação foi a $37^{\circ} \mathrm{C}$ por 72 horas, observando-se a ocorrência de células receptoras nif ${ }^{+}$e resistentes a drogas, conferida por genes plasmidiais das celulas doadoras.

3.19.3. Conjugação entre linhagens transformantes de. E. coli

O transformante CA77/101(9)2 isolado no item 
3.19.1, foi utilizado como linhagem doadora em cruzamentos com outros transformantes de E. coli 101(9) (item 3.16.2). Este ensaio teve como objetivo verificar a ocorrência de maior atividade de fixação de $\mathrm{N}_{2}$, nestes novos recombinantes.

A metodologia seguida foi a mesma do item anterior. Após a conjugação, as células foram semeadas em MMEC + ampicilina, uma vez que a 1 inhagem CA 77 apresentava re sistência a esta droga. A incubação foi por 72 horas a $37^{\circ} \mathrm{C}$ e selecionou-se as colônias de maior tamanho, procedendo-se em seguida, o teste da redução do acetileno para verificar a atividade da nitrogenase em comparação com cada uma das 1inhagens parentais.

\subsubsection{Conjugação entre 1 inhagens transformantes $n i f^{+}$ e isolado 9 com linhagens portadoras de plas- mídios com transposon.}

Foi realizada a conjugação entre os transformantes $n i f^{+}$e isolado 9 com a 1 inhagem de $E$. coli portadora de plasmídio com transposon pcBT01/HB101. Após a conjugação, as células foram semeadas em três meios diferentes: MMEC s/N + canamicina e tetraciclina; MMEC s/N + canamicina e MMEC s/N + tetraciclina. A incubação foi por 72 horas a 37 e $30^{\circ} \mathrm{C}$, dependendo das células receptoras utilizadas. Nos casos onde as células receptoras foram as do isolado 9, substituiu-se o MMEC s/N por LG, acrescido dos mesmos antibióticos. 


\section{RESULTADOS}

\subsection{Isolamento de bactérias fixadoras de $\mathrm{N}_{2}$}

Utilizando-se a metodologia descrita no item 3.3, obteve-se cerca de 50 isolados bacterianos, os quais foram purificados nos vários meios isentos de nitrogênio. Destes isolados bacterianos, apenas 6 apresentaram características morfofisiológicas diferentes (requerimentos nutricionais, aspecto da colônia, taxa de crescimento). Estes receberam a designação de 12B, 13-2, 20-AM, 5-3, 9 e 22 e, juntamente com as linhagens cedidas por outras instituições (Tabela 1), foram posteriormente submetidos a eletroforese em gel de agarose para verificação da presença de plasmídios. 


\subsection{Ocorrência de plasmídios embactérias fixadoras de $\mathrm{N}_{2}$}

Após a adaptação da metodologia para eletroforese em gel de agarose (item 3.4), foi feito umestudo com parativo das vārias amostras bacterianas fixadoras de $\mathrm{N}_{2} \cdot \mathrm{A}$ Figura 2 mostra o padrão de migração eletroforética das 1 inhagens que apresentaram plasmídios. Nas demais amostras não foram observados plasmídios em nenhum dos métodos de eletroforese realizados.

Considerando a possibilidade de que algumas linhagens fixadoras de $\mathrm{N}_{2}$ pudessem apresentar plasmídios não visíveis em eletroforese (devido ao pequeno número de cōpias), fez-se o tratamento com cloranfenicol (item 3.5) numa tentativa de amplificar o número de cópias destes plasmí dios. Verificou-se que após este tratamento, apenas a 1 inhagem 40-1 mostrou a presença de um plasmídio, o que não havia ocorrido antes deste tratamento. Além disso, os iso1ados 74-1, 40-1 IV e LAMS, não foram submetidos à eletrofo rese, pois houve muita dificuldade em se retirar a espessa camada de muco que os envolvia, dificultando a ocorrência de lise celular. Foi feita uma tentativa de eliminação es se muco com solução de EDTA, o que não teve sucesso.

De acordo com a mobilidade eletroforética em comparação com a migração de plasmídios com pesos moleculares conhecidos, obteve-se a reta de padronização (Figura 3) 


\begin{tabular}{cll} 
Canaleta & Linhagem & Peso Molecular (Md) \\
\hline 1 & $5-3$ & $40 *$ \\
2 & $2-2$ II & $64 *$ \\
3 & Rldrd19 & 62 \\
4 & Sa & 23 \\
5 & sp7 & 125 e 65 \\
6 & $40-1$ & $92 *$ \\
7 & p307 & 54 \\
\hline$*$ valores estimados (Figura 3) & \\
& CANALETA (No)
\end{tabular}

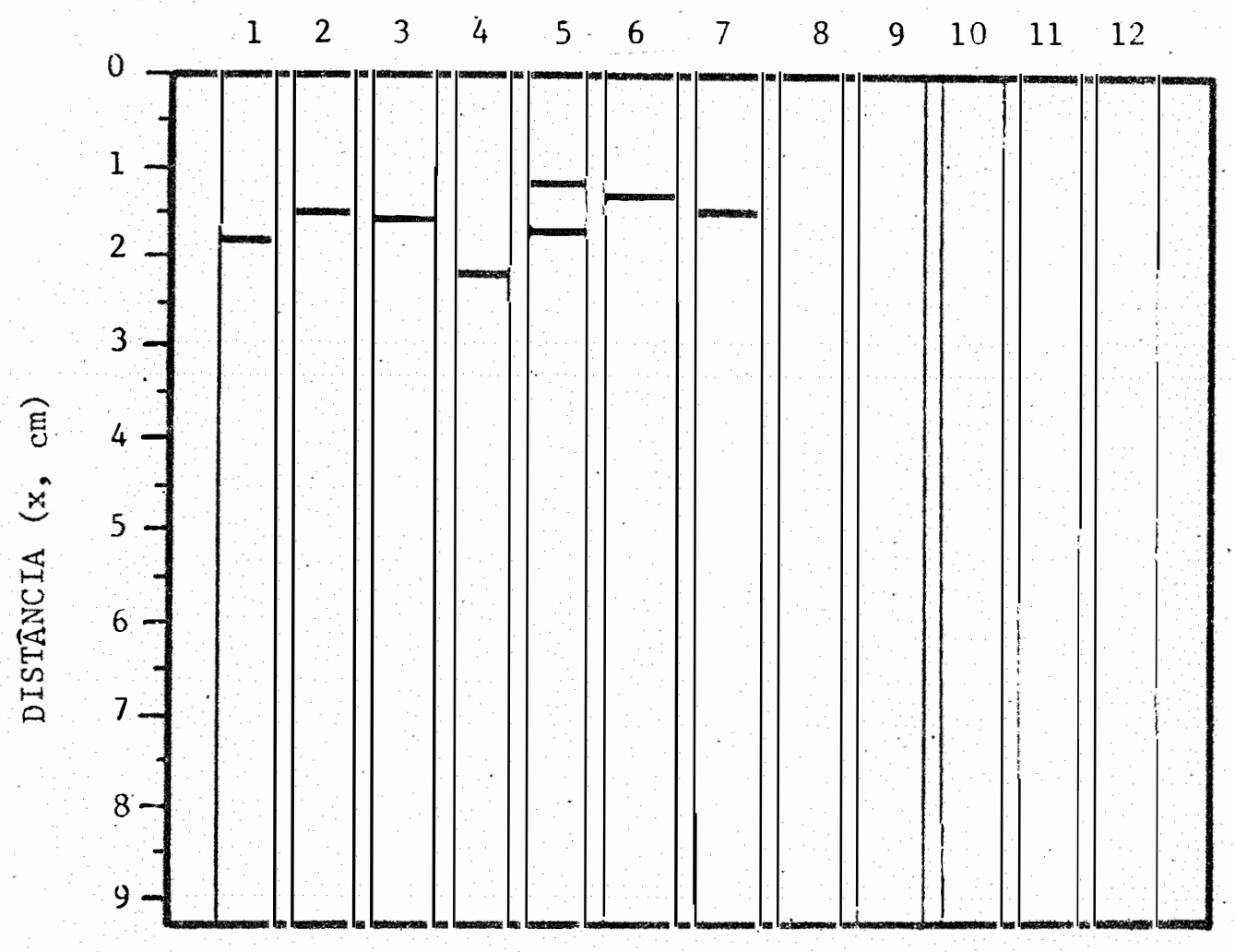

FIGURA 2 - Eletroforese em gel de agarose de isolados bacterianos fixadores assimbióticos de $\mathrm{N}_{2}$ e linhagens portadoras de plasmídios, com pesos moleculares conhecidos (canaletas $3,4,5$ e 7 ). 


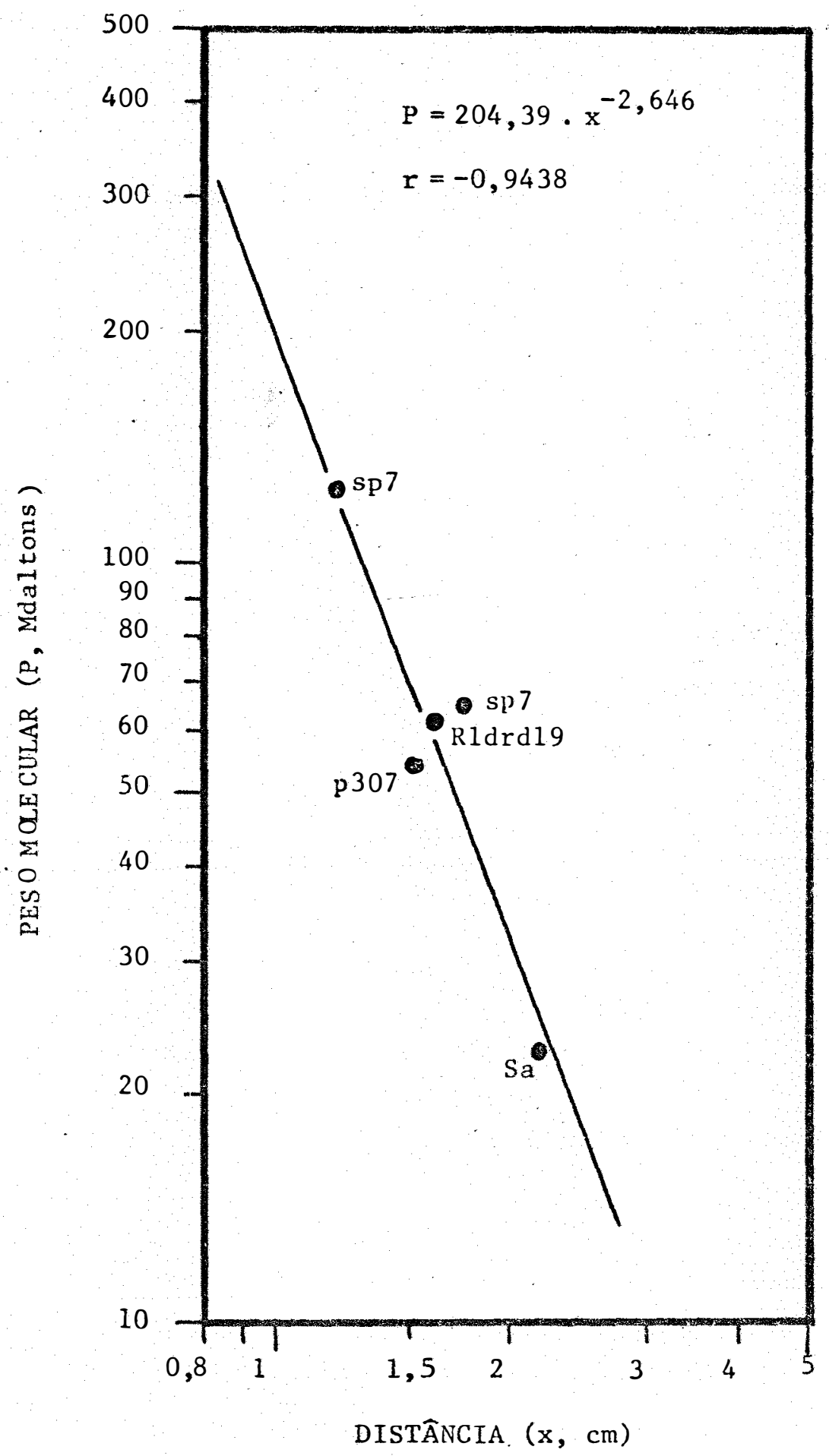

FigURA 3 - Reta de calibração para estimativa dos pesos moleculares de plasmídios a partir de linhagens padrões. 
e com isso foi possível estimar o peso molecular dos plasmí dios das amostras 2-2-II, 5-3 e 40-1 como sendo 64,40 e 92 Md, respectivamente.

\subsection{Eliminaçãode plasmídios em linhagens fixadoras de $\mathrm{N}_{2}$}

Cerca de 1500 colônias foram ensaiadas quanto à capacidade de fixar nitrogênio após o tratamento com a gentes de "cura" como brometo de etídio, acriflavina, acridina 1 aranja e calor $\left(44^{\circ} \mathrm{C}\right)$. Os dados referentes a estes ex perimentos estão da Tabela 2 .

TABELA 2 - Porcentagem de eliminação de plasmídios através do tratamento com agentes de "cura" em Iinhagens fixadoras de $\mathrm{N}_{2}$.

\begin{tabular}{lcccc}
\hline \multirow{2}{*}{ Amostras } & \multicolumn{3}{c}{ Tratamento* } \\
\cline { 2 - 5 } & $\begin{array}{c}\text { brometo de } \\
\text { etidio }\end{array}$ & acriflavina & $\begin{array}{c}\text { acridina } \\
\text { 1aranja }\end{array}$ & calor \\
\hline A. brasizense & 1,08 & 0,42 & 0,43 & 2,03 \\
$40-1$ & 3,52 & 0,43 & 0,25 & 10,30 \\
$5-3$ & 5,51 & 1,03 & 0,23 & 6,65 \\
$2-2$ I I & 4,60 & 1,52 & 0,83 &
\end{tabular}

* 90 - 100 colônias em cada tratamento 
Pode-se verificar que apenas na linhagem de A. brasizense houve alteração no processo de fixação de $\mathrm{N}_{2}$, após a eliminação dos plasmídios, enquanto que as demais con tinuaram apresentando crescimento em meio sem nitrogênio in corporado. A comprovação da perda dos plasmídios foi feita através da eletroforese em gel de agarose em um número significativo de colônias que apresentaram ou não crescimento em meio sem nitrogênio, uma vez que o carāter "fixação de $\mathrm{N}_{2}$ " foi o único critério levado em consideração.

Como já mencionado, não foram isoladas bacté rias cujos plasmídios tivessem genes relacionados ao proces so de fixação de nitrogênio. Desta forma, procurou-se entre os isolados bacterianos uma linhagem que pudesse ser utilizada em estudos genéticos envolvendo genes nif cromossomais. 0 isolado 9, não portador de plasmídio, foi utilizado neste sentido, uma vez que o mesmo apresentou boas características culturais, como crescimento rápido em vários meios isentos de nitrogênio incorporado (LG, LGB, Burk), fáa cil manipulação, além de ter colônias bem delimitadas, faci litando a"réplica em veludo" (LEDERBERG e LEDERBERG, 1952). Vários ensaios foram conduzidos com esta bactéria como obtenção de mutantes $n i f^{-}$, experimentos de transformação envolvendo mutantes $n i f^{-}$e linhagens de $E$. coli como receptoras e experimentos de conjugação entre os transformantes obtidos com outras linhagens de E. coli. 
o isolado 9 foi caracterizado como sendo do gềnero Azotobacter, espécie paspali (Figuras 4 e 5), de acor do com os critérios citados no item 3.8. Esta bactéria tem como característica morfológica, um grande pleomorfismo, de modo que após 2 dias de crescimento, as células apresentamse como filamentos, de comprimento variado, podendo atingir até $30 \mu \mathrm{m}$. Após 4 dias, verifica-se uma mistura de filamen tos longos e bastonetes de vários comprimentos. Tanto os bastonetes como os filamentos, movem-se ativamente em meio 1íquido e em culturas mais velhas aparecem células com forma semelhante a outras espécies de Azotobacter. Produzem cisto e cápsula, são Gram negativas e nos filamentos aparecem cadeias de grânulos que possivelmente darão origem aos cistos ou células mais curtas. Não se desenvolvem em caldo nutritivo, tendo bom crescimento em meio isento de nitrogênio (LG, Burk e LGB) contendo glicose e sacarose. Não utilizam, porém, o amido e manitol e forte produção de ácido é observada em meio contendo glicose e sacarose, o que pode ser também verificado pelo amarelecimento do agar com azul de bromotimol. A fixação de $\mathrm{N}_{2}$ ocorre em presença de oxigê nio, da mesma forma que em outras espécies de Azotobacter. Em relação à temperatura, verifica-se que o seu crescimento pode ocorrer tanto a 30 como a $37^{\circ} \mathrm{C}$ e numa faixa de pH vari àvel entre 5 e 9 . As colônias em meio sōlido sem nitrogênio são redondas, úmidas e elevadas, mas em culturas mais velhas tornam-se secas e leitosas, frequentementeirregulares. 

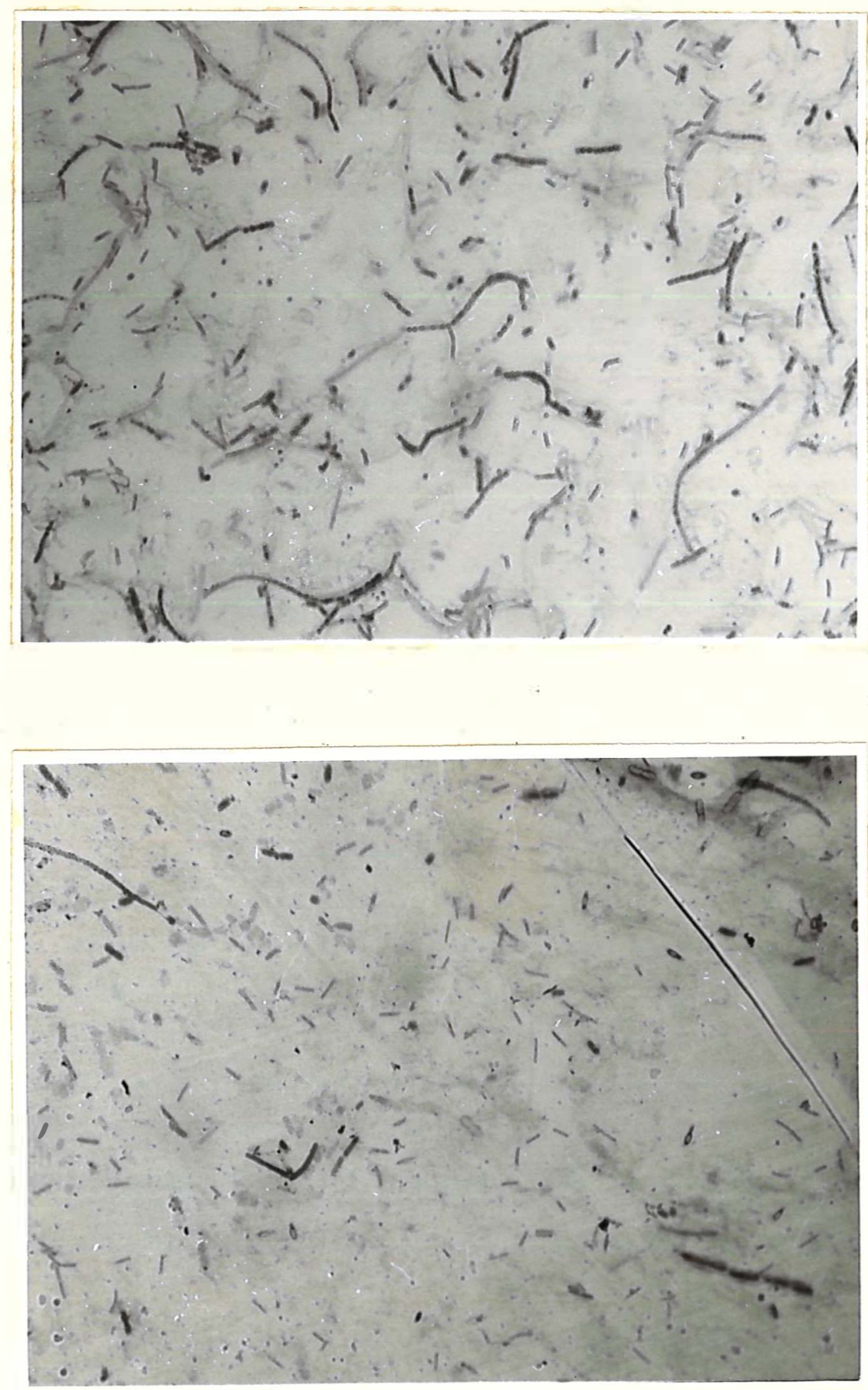

FIGURA 4 - Cultura do isolado 9 (A. paspali) em meio sem nitrogênio incorporado, coloração simples com azul de metileno (x 1000). Acima: cultura de 2 dias, apresentando filamentos longos; Abaixo: cultura de 4 dias apresentando cēlulas de comprimento intermediário e raras formas alongadas. 

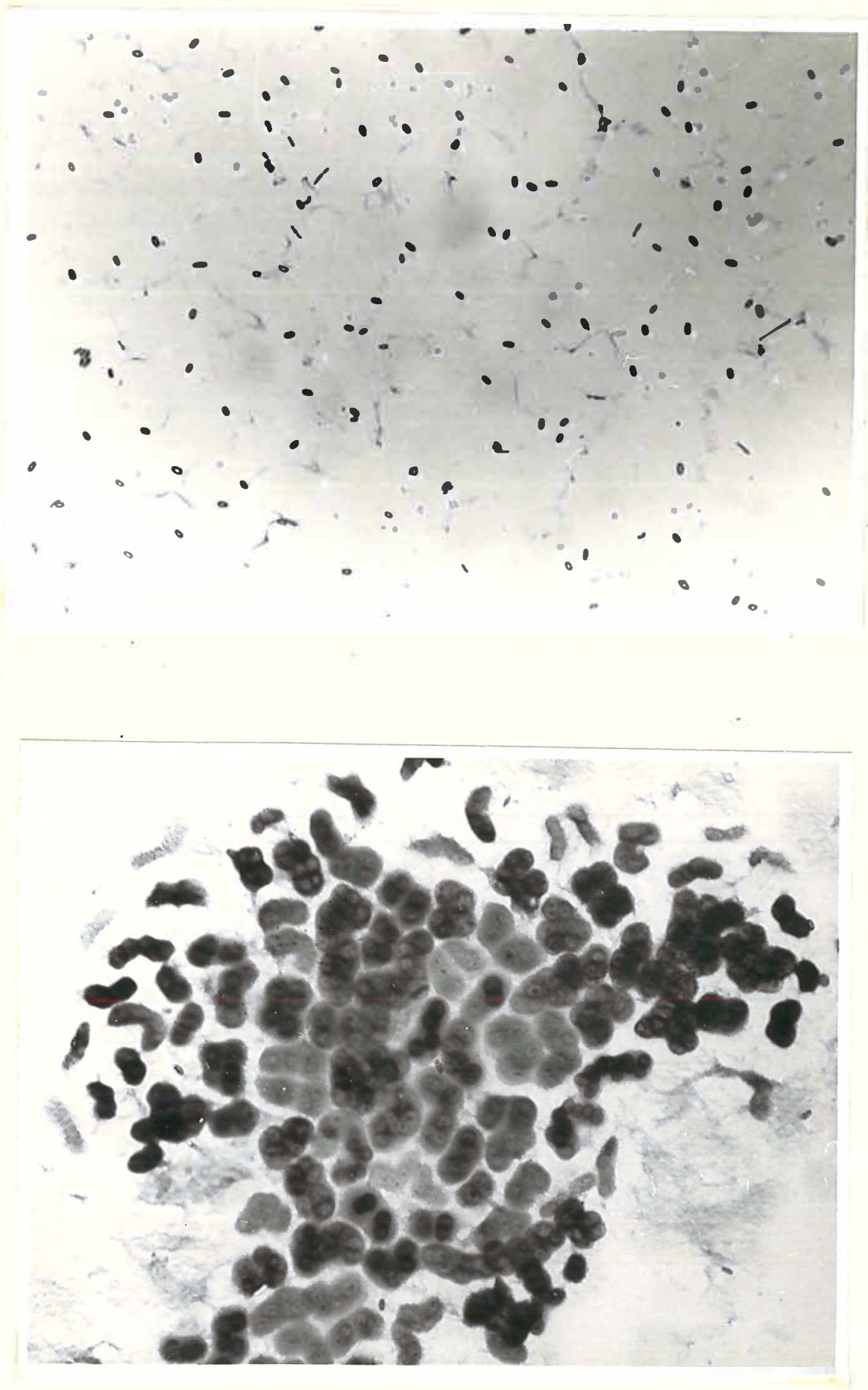

FIGURA 5 - Cultura do isolado 9 (A. paspali) em meio sem nitrogênio incor porado, coloração simples com azul de metileno ( $x$ 1000). Acima: cultura de 7 dias, com predominância de formas cocoides; Abaixo: cultura de 10 dias onde aparecem cistos. 
4.4. Nível de resistência a drogas no isolado 9

os níveis de resistência do isolado 9 para quatro antibiōticos, são mostrados na Tabela 3. Conforme pode ser observado, a linhagem já possui certa resistência natural à ampicilina demonstrado pelo seu crescimento imediato em meio contendo $20 \mu \mathrm{g} / \mathrm{ml}$, o que não aconteceu com os outros antibióticos. Estes dados foram posteriormente utilizados no isolamento de mutantes resistentes.

TABELA 3 - Nível de resistência do isolado 9 a antibióticos.

\begin{tabular}{ccccc}
\hline $\begin{array}{c}\text { concentração } \\
(\mu \mathrm{g} / \mathrm{m} 1)\end{array}$ & $\begin{array}{c}\text { ampi- } \\
\text { cilina }\end{array}$ & $\begin{array}{c}\text { tetra- } \\
\text { ciclina }\end{array}$ & $\begin{array}{c}\text { cloran- } \\
\text { fenicol }\end{array}$ & $\begin{array}{c}\text { cana- } \\
\text { micin }\end{array}$ \\
\hline 0 & + & + & + & + \\
1 & + & + & + & + \\
2 & + & - & + & + \\
5 & + & - & + & - \\
10 & + & - & - & - \\
20 & + & - & - & - \\
50 & - & - & -
\end{tabular}

+ crescimento

- ausência de crescimento 
4.5. Curva de sobrevivência e obtenção de mutantes nif à irradiação ultra-violeta e tratamento com àcido nitroso

As curvas de sobrevivência aos tratamentos com luz ultra-violeta e ácido nitroso foram realizadas, a fim de se determinar as melhores condiçoes para o isolamento de mutantes nif ${ }^{-}$. As Tabelas 4 e 5 mostramesses dados e a representação gráfica está na Figura 6 .

TABELA 4 - Sobrevivência do isolado 9 à irradiação ultravioleta $\left(93,6 \mathrm{~J} \cdot \mathrm{m}^{-2} \cdot \mathrm{min}^{-1}\right)$.

\begin{tabular}{ccc}
$\begin{array}{c}\text { Tempo } \\
(\mathrm{minutos})\end{array}$ & $\begin{array}{c}\text { No de Sobreviventes } \\
(\mathrm{ce} 1 \mathrm{lu} 1 \mathrm{as} / \mathrm{m} 1)\end{array}$ & $\begin{array}{c}\text { Porcentagem de } \\
\text { Sobrevivência }\end{array}$ \\
\hline 0 & $6,3 \times 10^{8}$ & $1,00 \times 10^{2}$ \\
0,5 & $5,1 \times 10^{8}$ & $8,09 \times 10^{1}$ \\
1,0 & $4,5 \times 10^{7}$ & $7,14 \times 10^{0}$ \\
1,5 & $1,8 \times 10^{7}$ & $2,85 \times 10^{0}$ \\
2,0 & $3,8 \times 10^{5}$ & $6,03 \times 10^{-2}$ \\
3,0 & $4,3 \times 10^{3}$ & $7,61 \times 10^{-4}$ \\
4,0 & $2,5 \times 10^{2}$ & $3,96 \times 10^{-5}$ \\
\hline
\end{tabular}


TABELA 5 - Sobrevivência do isolado 9 ao tratamento com àcido nitroso.

\begin{tabular}{ccc}
$\begin{array}{c}\text { Tempo } \\
(\mathrm{minutos})\end{array}$ & $\begin{array}{c}\text { No de Sobreviventes } \\
(\mathrm{ce} 1 \mathrm{lus} / \mathrm{m} 1)\end{array}$ & $\begin{array}{c}\text { Porcentagem de } \\
\text { Sobreviventes }\end{array}$ \\
\hline 0 & $3,5 \times 10^{8}$ & $1,00 \times 10^{2}$ \\
4 & $4,8 \times 10^{7}$ & $1,37 \times 10^{1}$ \\
8 & $2,0 \times 10^{6}$ & $5,71 \times 10^{-1}$ \\
12 & $1,6 \times 10^{4}$ & $4,57 \times 10^{-3}$ \\
16 & $3,4 \times 10^{2}$ & $9,71 \times 10^{-5}$ \\
20 & $1,2 \times 10^{2}$ & $3,40 \times 10^{-7}$
\end{tabular}

Considerando os valores correspondentes às curvas de sobrevivência, escolheu-se 2 minutos como o tempo de irradiação para o tratamento com 1 uz ultra-violeta e 8 mi nutos para o tratamento com ácido nitroso por causarem menos de $1 \%$ de sobrevivência e, portanto, considerado suficiente para induzir alta taxa de mutação.

Foram selecionadas 6 e 10 colônias mutantes $n i f^{-}$após tratamento com ultra-violeta e àcido nitroso, respectivamente. Estes mutantes foram em seguida submetidos a auxanografia, a fim de verificar se a sua incapacidade de crescimento em meio sem nitrogênio, era realmente por alteração na nitrogenase ou devida a alguma deficiência nu- 


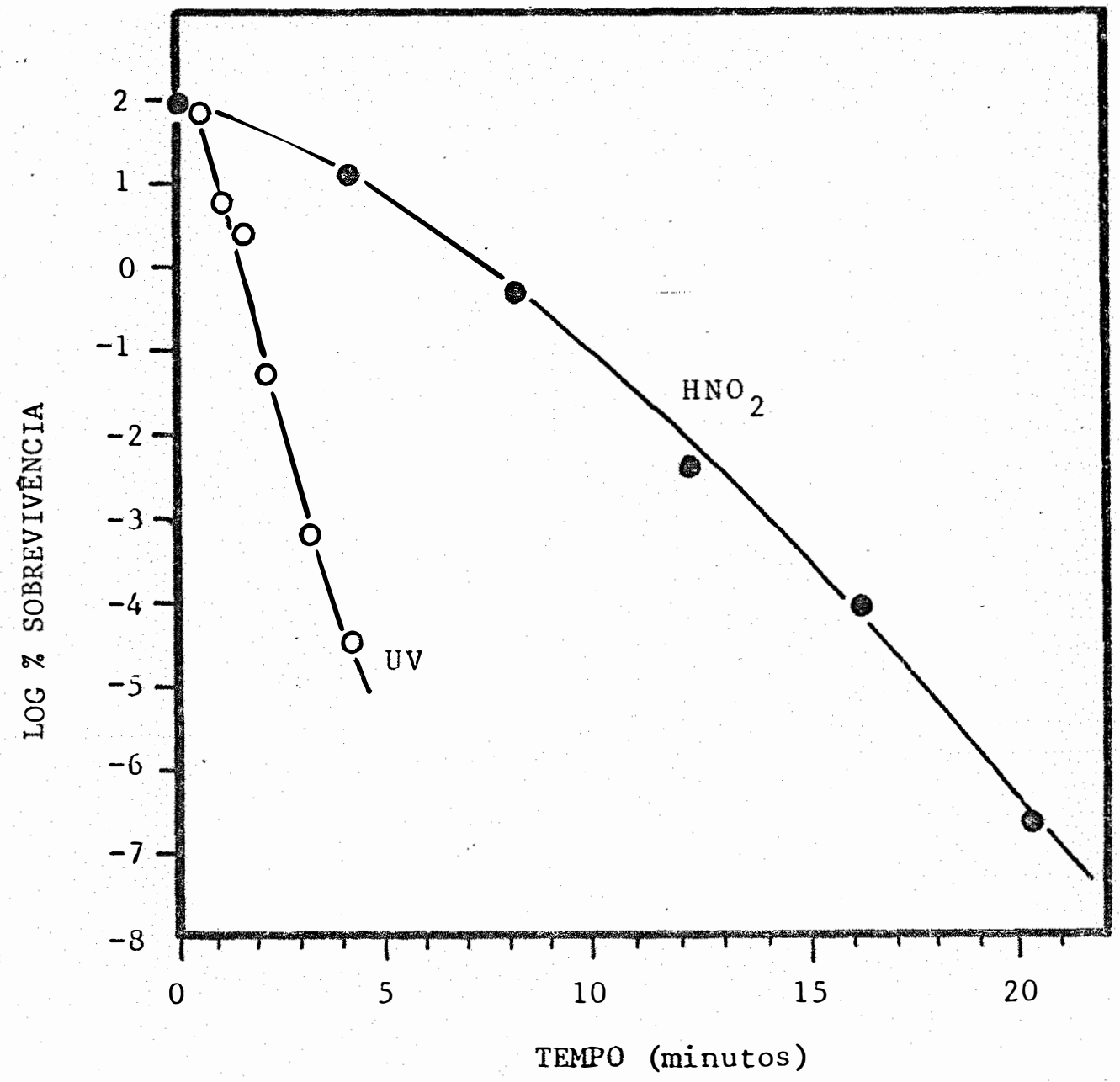

FIGURA 6 - Curva de sobrevivência do isolado 9 à irradiação ultra-violeta (UV) e tratamento com ácido nitroso ( $\mathrm{HNO}_{2}$ ). 
tricional (auxotrofia) que os impedia de desenvolveremmeio mínimo. Conforme já foi descrito no item 3.13, os mutantes foram semeados em meio isento de nitrogênio, acrescido de fontes de aminoácidos, ácidos nucleicos ou vitaminas. Con vém salientar que em todos estes casos, a fonte de suplemen taçao, em especial de aminoācidos, não atingiu a concentração de $300 \mu g / m 1$ capaz de inibir o processo de fixação de nitrogênio nesta bactéria (avaliada pela redução do aceti 1eno). Verificou-se que dos 16 mutantes nif obtidos inici almente, apenas 5 mantiveram esta condição após suplementação com os diferentes requerimentos. Isto mostrou que real mente a sua incapacidade de crescimento em meio sem nitrogê nio não estava relacionada com deficiência nutricional e sim especificamente com alterações da nitrogenase. Dos $11 \mathrm{mu}-$ tantes restantes, 8 reverteram para $n i f^{+}$após algumas subculturas e 3 mostraram ser auxotróficos, sendo 2 capazes de crescer em meio suplementado com vitaminas, mostrando deficiência para a vitamina $B_{1}$ e o outro apresentou crescimento em meio com ácido nucleico de leveduras, mostrando deficiên cia para timina.

Os 5 mutantes que comprovadamente mostraram ser $n i f^{-}$, juntamente com culturas do isolado 9 , foram poste riormente utilizados na seleção de mutantes resistentes a drogas. Para isso observou-se os dados referentes aos níveis de resistência do isolado 9 aos antibióticos (Tabela 3). 
A seleção de células resistentes foi necessāria para que se pudesse dispor de linhagens doadoras de DNA, que atuasem como marcadores em experimentos de transformação. Desta forma, além da característica "fixação de $\mathrm{N}_{2}$ ", pode-se utilizar a marca de resistência na seleção de transformantes. Foram obtidas 10 colonias do isolado 9 que cresceramem LG + $50 \mu \mathrm{g} / \mathrm{ml}$ de ampicilina, 3 colônias em meio com $2 \mu \mathrm{g} / \mathrm{ml}$ de tetraciclina, 5 em $10 \mu g / m l$ de cloranfenicol e 6 em $5 \mu \mathrm{g} / \mathrm{ml}$ de canamicina. Também foram isoladas células resistentes a $50 \mu g / m l$ de ampicilina a partir de cada uma das linhagens mutantes nif.

\subsection{Experimentos de transformação}

Apōs a extração do DNA do isolado 9 e mutantes nif (item 3.15), fez-se uma série de experimentos de transformações interespecíficas e intergenéricas, com o objetivo de estudar o comportamento de genes fixadores de $\mathrm{N}_{2}$, em populações selvagens de bactérias fixadoras de vida livre como é o caso do isolado 9 (A. paspali). Nestes ensaios procurou-se localizar os genes nif $f^{-}$ao longo do genoma bacteriano, além de observar sua possível transferência para outros organismos não fixadores de $\mathrm{N}_{2}$. 


\subsubsection{Transformação interespecifica}

os mutantes nif $f^{-}$obtidos a partir do isolado 9 (item 4.6) foram utilizados como células receptoras em ex perimentos de transformação onde o DNA doador foi provenien te de células desta mesma linhagem. A seleção dos transfor mantes foi em função da recuperação da capacidade de fixar $\mathrm{N}_{2}\left(n i f^{+}\right)$por parte dos mutantes $n i f^{-}$, o que pode ser verificado através do crescimento de colônias em meio sem nitro gênio incorporado.

A frequência de transformantes $n i f^{+}$foi calculada levando-se em consideração o nümero total de células receptoras utilizadas e os dados referentes a este experimento são mostrados na Tabela 6 .

TABELA 6 - Porcentagem de recombinantes $n i f^{+}$da transformação entre mutantes $n i f^{-}$e DNA do isolado 9 .

\begin{tabular}{cr}
\hline $\begin{array}{c}\text { Linhagens } \\
\text { Receptoras* }\end{array}$ & $\begin{array}{r}\text { Porcentagem } \\
\text { Transformantes }\end{array}$ \\
\hline$i f_{1}^{-}$ & $1,7 \times 10^{-2}$ \\
$n i f_{2}^{-}$ & $8,5 \times 10^{-3}$ \\
$n i f_{3}^{-}$ & $4,0 \times 10^{-2}$ \\
$n i f_{4}^{-}$ & $1,1 \times 10^{-3}$ \\
$n i f_{5}^{-}$ & $3,2 \times 10^{-3}$
\end{tabular}

* número de células utilizadas foi de $10^{7}-10^{8}$ cels $/ \mathrm{m} 1$ 
Em cada experimento foi feito simultaneamente um controle dos mutantes $n i f^{-}$a fim de se verificara pos sível ocorrência de reversão. Observou-se desta forma, que apenas os mutantes $n i f_{2}^{-}$e $n i f_{5}^{-}$apresentaram uma reversão para $n i f^{+}$em torno de $3,10^{-7} \%$, o que foi considerado no cá1 culo da frequência de recombinação.

\subsubsection{Transformação entre mutantes $n i f^{-}$}

Os mutantes $n i f^{-}$descritos no item 4.6, foram transformados com DNA extraido destes mesmos mutantes em to das as combinações possíveis, onde as linhagens doadoras car regavam uma marca conferindo resistência a ampicilina. As porcentagens de recombinação nestas transformações são mostradas na Tabela 7 e a Figura 7 mostra a ordem das mutações afetando a fixação de nitrogênio.

o aparecimento de células $n i f^{+}$indicou umare combinação do material genético correspondente às mutaçóes das duas 1 inhagens. Assim, recombinantes nif $^{+}$só puderam ocorrer quando a mutação do doador não foi a mesma do genoma receptor. Nestas transformações, verificou-se que a mar ca para resistência a ampicilina apareceu em apenas 2 experimentos envolvendo $n i f_{4}^{-}\left(n i f_{4}^{-} \times n i f_{5}^{-}\right.$e $\left.n i f_{4}^{-} \times n i f_{1}^{-}\right)$.

Em todos os casos foi feito um controle para se verificar uma possível reversão dos mutantes nif ${ }^{-}$. 
TABELA 7 - Porcentagem de transformantes $n i f^{+}$obtidos de cru zamentos entre mutantes $n i f^{-}$e DNA destas mesmas linhagens .

Linhagens Receptoras*

Linhagens Doadoras

$\begin{array}{lccccc} & n i f_{1}^{-} & n i f_{2}^{-} & n i f_{3}^{-} & n i f_{4}^{-} & n i f_{5}^{-} \\ n_{n i f_{1}^{-}} & 0 & 5,4 \times 10^{-4} & 7,2 \times 10^{-3} & 3,5 \times 10^{-3} & 8,7 \times 10^{-7} \\ n i f_{2}^{-} & 1,3 \times 10^{-3} & 1,0 \times 10^{-7} & 4,5 \times 10^{-6} & 1,9 \times 10^{-3} & 8,1 \times 10^{-3} \\ n i f_{3}^{-} & 6,7 \times 10^{-3} & 5,6 \times 10^{-5} & 0 & 2,8 \times 10^{-3} & 5,2 \times 10^{-3} \\ n i f_{4}^{-} & 7,0 \times 10^{-3} & 2,6 \times 10^{-3} & 3,0 \times 10^{-3} & 3,2 \times 10^{-7} & 3,1 \times 10^{-3} \\ n i f_{5}^{-} & 0 & 1,5 \times 10^{-4} & 7,3 \times 10^{-3} & 8,0 \times 10^{-3} & 3,8 \times 10^{-7}\end{array}$

* númeró de células receptoras utilizadas foi de $10^{7}-10^{8}$ cé-1ulas/ml

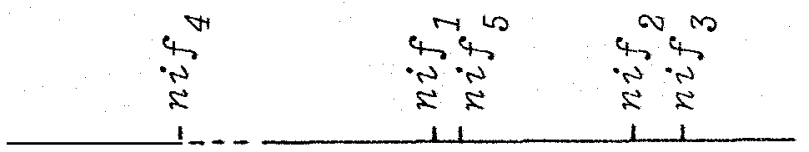

FIGURA 7 - Ordem das mutações afetando a fixação de $\mathrm{N}_{2} \cdot$ As distâncias entre as mutações não são dadas em es cal as. 


\section{-4.6.3. Transformação intergenérica}

Neste caso, o DNA do isolado 9 foi utilizado em processos de transformação onde as células receptoras foram da bactéria E. coli e levedura S. cerevisiae. obteve-se transformantes apenas quando as células receptoras foram de E. coli HB101, C600, CA77 e R1drd19.

As colônias recombinantes obtidas inicialmen te foram replicadas novamente para o mesmo meio isentode ni trogênio incorporado, para confirmação da condição de nif ${ }^{+}$. Nessas condições, poucas destas colônias mantiveram-se está veis. Conforme pode ser observado na Tabela 8 , apenas 6 colônias da 1 inhagem HB101 e 2 da CA77 apresentaram as características da espécie e crescimento em meio isento de ni trogênio. Estas foram designadas de 101(9)1 a 6 e CA77(9) 1 e 2 . 
TABELA 8 - Transformação de 1 inhagens de $E$. coli e levedura S. cerevisiae com DNA do isolado 9 .

\begin{tabular}{|c|c|c|c|}
\hline $\begin{array}{l}\text { Linhagens } \\
\text { Receptoras * }\end{array}$ & $\begin{array}{c}\text { Nümero Total de } \\
\text { Transformantes } \\
\text { nif }{ }^{+}\end{array}$ & $\begin{array}{l}\text { Nümero de } \\
\text { Transformantes } \\
\text { niff Estāveis }\end{array}$ & $\begin{array}{c}\text { Porcentagem } \\
\text { de }\end{array}$ \\
\hline HB 101 & 26 & 6 & $4,0 \times 10^{-6}$ \\
\hline C 600 & 15 & 0 & $2,1 \times 10^{-6}$ \\
\hline 711 & 0 & 0 & 0 \\
\hline $\mathrm{CA} 77$ & 8 & 2 & $1,7 \times 10^{-6}$ \\
\hline $\mathrm{Sa}$ & 0 & 0 & 0 \\
\hline R1drd 19 & 6 & 0 & $5,2 \times 10^{-7}$ \\
\hline Levedura $X_{2180}$ & 0 & 0 & 0 \\
\hline
\end{tabular}

* o nümero de células receptoras utilizadas foi de $10^{7}-10^{8}$ cê 1 u 1 as $/ \mathrm{m} 1$

** nümero total de transformantes $n i f^{+}$em relação ao nümero de células receptoras utilizadas 


\subsection{Atividade da nitrogenase e crescimento dos transfor-} mantes de $E$. coli

Os dados de atividade da nitrogenase para os transformantes $n i f^{+}$, de $E$. coli e isolado 9 (doadora) são apresentados na Tabela 9. Nas Tabelas 10 e 11 estão os dados re ferentes ao crescimento destas mesmas linhagens e da $E$. coli HB101 (receptora) em meio com e sem nitrogênio incorporado, respectivamente e a representação gräfica nas Figuras 8 e 9 . 0 aspectodestas culturas em Placas de Petri pode ser observado na Figura 10 .

TABELA 9 - Atividade danitrogenase nos transformantes de $E$. coli e isolado 9 medida pela redução do acetileno.

\begin{tabular}{lccc}
\hline \multicolumn{5}{c}{ Produção de $\mathrm{C}_{2} \mathrm{H}_{4}$} & $($ nmoles/hora $)$ \\
\hline Linhagem & Produção & Linhagem & Produção \\
\hline Iso1ado 9 & $1,42 \times 10^{3}$ & $101(9) 1$ & $26,0 \times 10^{-3}$ \\
$101(9) 2$ & $30,9 \times 10^{-3}$ & $101(9) 3$ & $8,1 \times 10^{-3}$ \\
$101(9) 4$ & $16,3 \times 10^{-3}$ & $101(9) 5$ & $17,9 \times 10^{-3}$ \\
$101(9) 6$ & $21,1 \times 10^{-3}$ & CA77(9) 1 & $1,6 \times 10^{-3}$ \\
CA77(9) 2 & $6,3 \times 10^{-3}$ & & \\
\hline
\end{tabular}


TABEla 10 - Crescimento dos transformantes $n i f^{+}$de $E$. coli, linhagem HBIOI (receptora) e isolado 9 (doadora) em meio com nitrogênio incorporado.

\begin{tabular}{|c|c|c|c|c|c|c|c|c|}
\hline \multirow{2}{*}{$\begin{array}{c}\text { Tempo } \\
\text { (horas) }\end{array}$} & \multicolumn{8}{|c|}{$\begin{array}{l}\text { Linhagens Bacterianas } \\
\text { Absorbância } \quad(620 \mathrm{~nm})\end{array}$} \\
\hline & 9 & 101 & $101(9) 1$ & $101(9) 2$ & $101(9) 3$ & $101(9) 4$ & $101(9) 5$ & $101(9) 6$ \\
\hline 6 & 0,01 & 0,05 & 0,01 & 0,02 & 0,01 & 0,01 & 0,02 & 0,01 \\
\hline 12 & 0,03 & 0,32 & 0,02 & 0,03 & 0,02 & 0,03 & 0,10 & 0,09 \\
\hline 20 & 0,12 & 0,65 & 0,08 & 0,25 & 0,31 & 0,30 & 0,15 & 0,23 \\
\hline 28 & 0,45 & 0,97 & 0,30 & 0,32 & 0,36 & 0,38 & 0,35 & 0,32 \\
\hline 36 & 0,65 & 1,71 & 0,43 & 0,41 & 0,44 . & 0,41 & 0,45 & 0,39 \\
\hline 44 & 0,85 & 1,80 & 0,62 & 0,55 & 0,55 & 0,63 & 0,58 & 0,47 \\
\hline 52 & 1,02 & 1,81 & 0,62 & 0,73 & 0,56 & 0,63 & 0,60 & 0,56 \\
\hline 60 & 1,01 & 1,82 & 0,63 & 0,73 & 0,56 & 0,70 & 0,65 & 0,60 \\
\hline 70 & 1,01 & 1,82 & 0,63 & 0,75 & 0,57 & 0,75 & 0,69 & 0,61 \\
\hline
\end{tabular}


TABELA 11 - Crescimento dos transformantes $n i f^{+}$de E. coli, linhagem HB101 (receptora) e isolado 9 (doadora) em meio sem nitrogênio incorporado.

\begin{tabular}{|c|c|c|c|c|c|c|c|c|}
\hline \multirow{2}{*}{$\begin{array}{l}\text { Tempo } \\
\text { (horas) }\end{array}$} & \multicolumn{8}{|c|}{$\begin{array}{l}\text { Linhagens Bacterianas } \\
\text { Absorbancia (620 } \mathrm{nm})\end{array}$} \\
\hline & 9 & 101 & $101(9) 1$ & $101(9) 2$ & $101(9) 3$ & $101(9) 4$ & $101(9) 5$ & $101(9) 6$ \\
\hline 6 & 0,01 & 0 & 0,02 & 0,01 & 0,01 & 0,02 & 0,01 & 0,00 \\
\hline 12 & 0,015 & 50 & 0,025 & 0,03 & 0,02 & 0,026 & 0,015 & 0,01 \\
\hline 20 & 0,09 & 0 & 0,08 & 0,08 & 0,03 & 0,07 & 0,03 & 0,02 \\
\hline 28 & 0,32 & 0 & 0,13 & 0,16 & 0,08 & 0,11 & 0,08 & 0,04 \\
\hline 36 & 0,46 & 0 & 0,19 & 0,21 & 0,09 & 0,15 & 0,10 & 0,09 \\
\hline 44 & 0,52 & 0 & 0,25 & 0,28 & 0,12 & 0,22 & 0,15 & 0,13 \\
\hline 52 & 0,73 & 0 & 0,30 & 0,30 & 0,25 & 0,29 & 0,30 & 0,18 \\
\hline 60 & 0,84 & 0 & 0,31 & 0,34 & 0,25 & 0,31 & 0,34 & 0,25 \\
\hline 70 & 0,83 & 0 & 0,31 & 0,35 & 0,26 & 0,35 & 0,35 & 0,27 \\
\hline
\end{tabular}




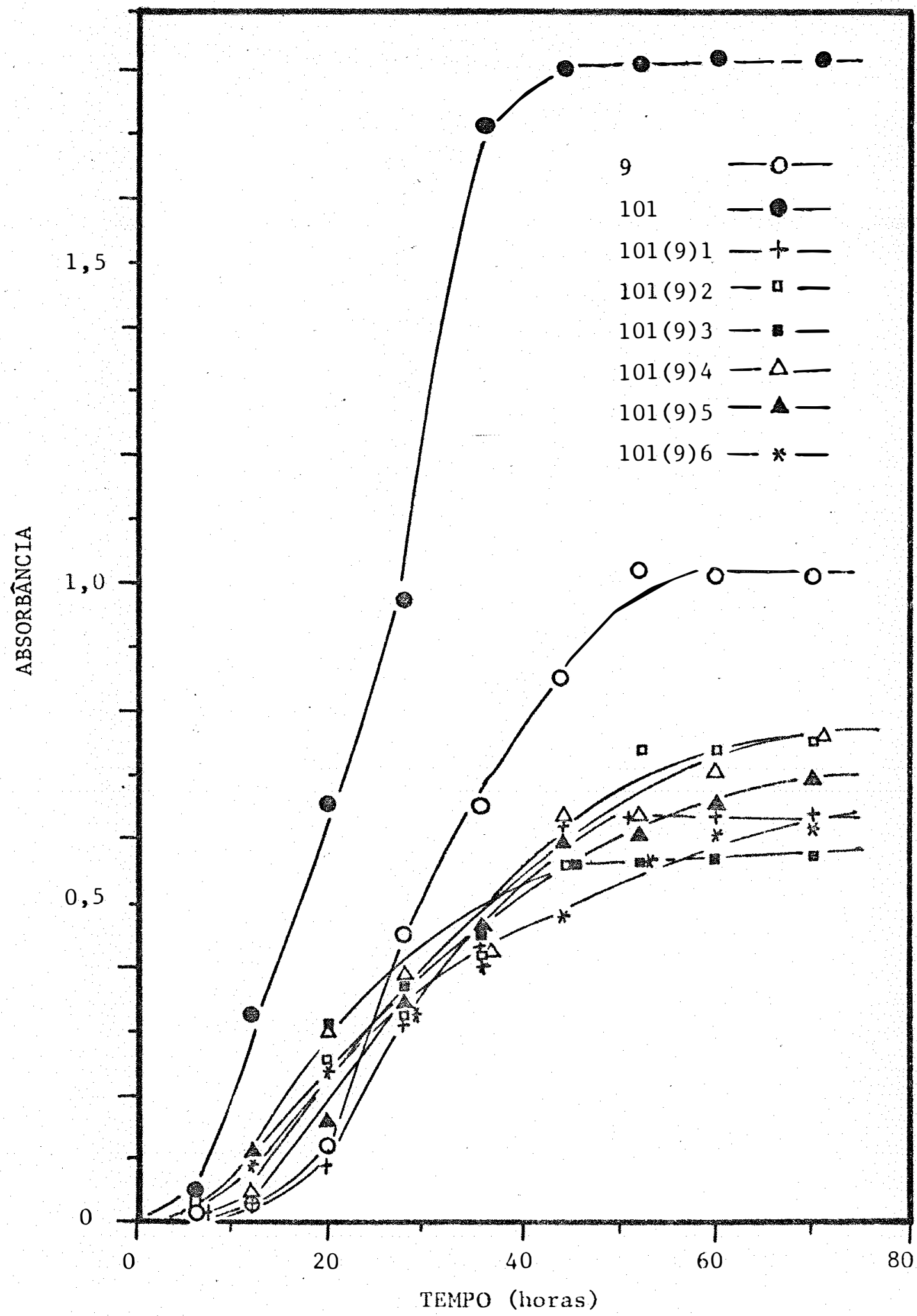

FIGURA 8 - Curvas de crescimento dos transformantes, 1inhagem HBl01 de E. coli e isolado 9 em meio com nitrogênio incorporado. 


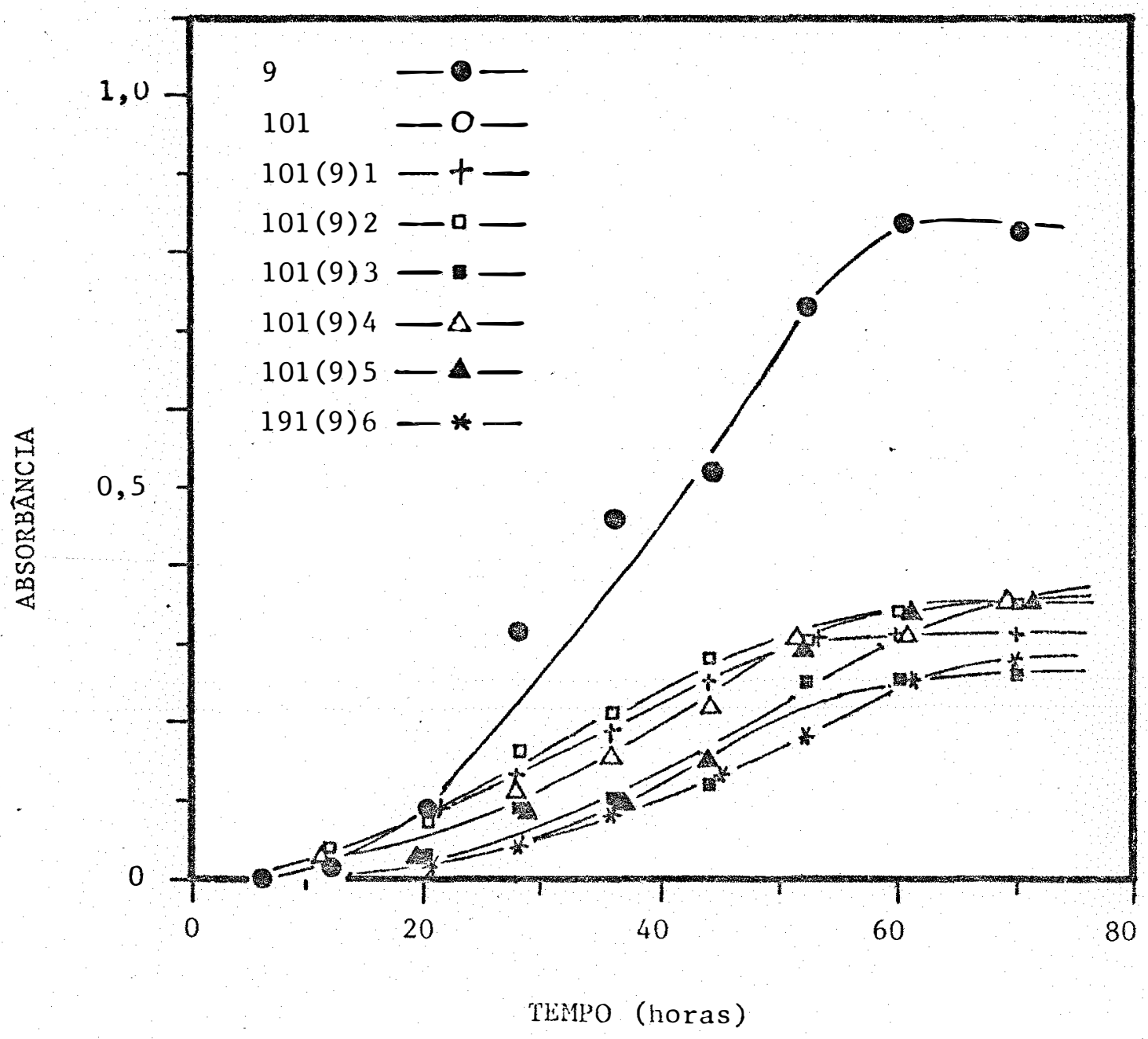

FIGURA 9 - Curvas de crescimento dos transformantes de $E$. coli e Isolado 9 em meio sem nitrogênio incorporado. 

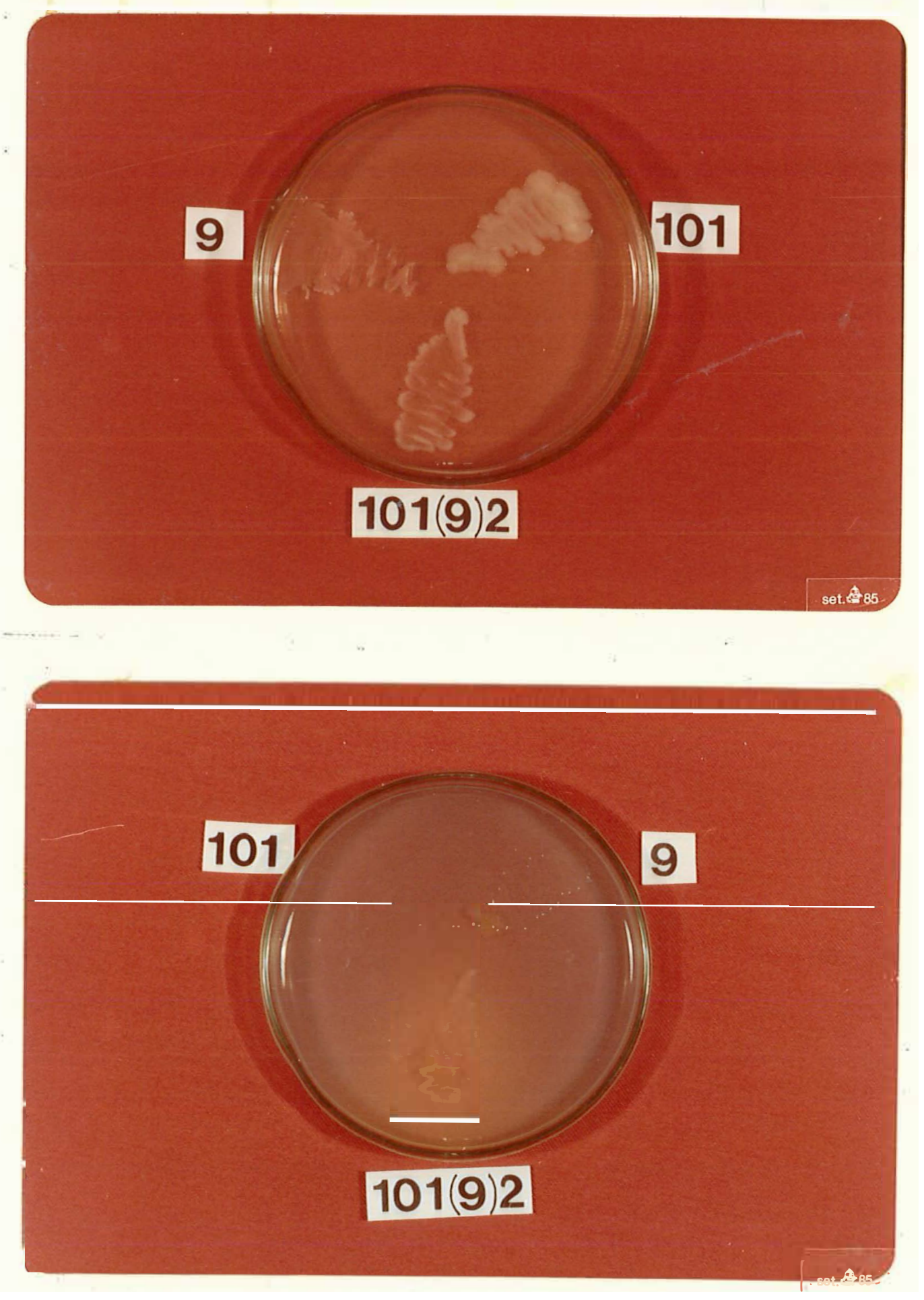

FIGURA 10 - Cultura de 3 dias das linhagens HB101, 9 e transformante $101(9) 2 \mathrm{~cm}$ meio com nitrogênio (acima) e sem nitrogênio (abaixo). 


\subsection{Experimentos de conjugaçao}

Uma série de experimentos de conjugação foram realizados entre transformantes de $E$. coli e várias linhagens doadoras (Hfr ou portadoras de plasmídios) desta mesma bactéria, a fim de se verificar a possível mobilização dos genes nif.

\subsubsection{Conjugação entre transformantes $101(9)$ e 1 i- nhagens de $E$. coli portadoras de plasmídios.}

Com o objetivo de comprovar serem os transformantes realmente da linhagem E. coli, fez-se inicialmente conjugação com linhagens portadoras de plasmídios conjugativos.

Conforme mostram os dados da Tabela 12, a con jugação ocorreu em alguns casos, conseguindo-se isolar coló nias resistentes a drogas e fixadoras de nitrogênio. A trans ferência do plasmídio só ocorreu quando a linhagem doadora foi Rldrd19, com exceção do cruzamento envolvendo 101(9) 2 x Sa, onde também ocorreu conjugação.

As colônias resistentes a drogas e fixadoras de $\mathrm{N}_{2}$ selecionadas, foram submetidas à eletroforese em gel de agarose, e apresentaram a banda correspondente ao plas mídio, da mesma forma que a linhagem doadora. Estas foram 
designadas de R1/101(9)1, R1/101(9)2, R1/101(9) 4 e R1/101(9)5 e os recombinantes selecionados no cruzamento entre CA77 (Hfr) e transformantes, foram designados de CA77/101(9)2.

TABELA 32 - Porcentagem de conjugação entre transformantes $101(9)$ e linhagens de E. coli portadoras de plas mídio.

\begin{tabular}{|c|c|c|c|c|c|c|}
\hline \multirow{2}{*}{$\begin{array}{l}\text { Linhagens } \\
\text { Doadoras } \\
\text { de E. coli }\end{array}$} & \multicolumn{6}{|c|}{ Linhagens Receptoras } \\
\hline & $101(9) 1$ & $101(9) 2$ & $101(9) 3$ & $101(9) 4$ & $101(9) 5$ & 101( \\
\hline $\mathrm{Sa}$ & 0 & $1,2 \times 10^{-4}$ & 0 & 0 & 0 & \\
\hline Rldrd19 & $3,7 \times 10^{-3}$ & $1,6 \times 10^{-3}$ & 0 & $1,1 \times 10^{-3}$ & $4,3 \times 10^{-3}$ & \\
\hline $\begin{array}{l}\text { CA77 } \\
(A m p)\end{array}$ & 0 & $5,0 \times 10^{-5}$ & 0 & 0 & 0 & \\
\hline
\end{tabular}

os recombinantes obtidos neste experimento, foram conjugados com as 1 inhagens receptoras de $E$. coli C600 e 711, para se verificar a possibilidade dos genes nif- estarem no plasmídio R. Desta forma, uma vez sendo transferi do o plasmídio, a bactéria receptora apresentaria resistência a drogas e capacidade de fixar $\mathrm{N}_{2}$. Foram obtidas colonias receptoras resistentes a drogas, indicando que o plasmídio foi transferido, masessas. continuaram incapazes de 
fixar $\mathrm{N}_{2}$.

4.8.2. Conjugação entre linhagens transformantes de E. $\operatorname{col} i$

Considerando que os transformantes de $E$. coli apresentavam diferentes segmentos de DNA, fez-se a conjugação entre a possível linhagem doadora CA77/101(9)2 (selecio nada no item 4.8.1) com transformantes 101(9). Este experi mento teve o objetivo de aumentar a eficiência de fixação de $\mathrm{N}_{2}$ entre os transformantes, comprovadamente baixas.

Selecionou-se colônias recombinantes de maior tamanho (Tabela 13) e estas foram ensaiadas conjuntamente com as linhagens parentais quanto a atividade de nitrogenase, pela técnica da redução do acetileno, não havendo diferença significativa nos valores encontrados.

TABELA 13 - Número de colônias de maior tamanho selecionadas a partir de conjugação entre os transforman tes CA77/101(9)2 e $101(9)$.

\begin{tabular}{|c|c|c|c|c|}
\hline \multirow{2}{*}{$\begin{array}{l}\text { Linhagem } \\
\text { Doadora }\end{array}$} & & Linhagens & Receptoras & \\
\hline & $101(9) 1$ & $101(9) 2$ & $101(9) 4$ & $101(9) 5$ \\
\hline CA77/101(9) 2 & 8 & 10 & 6 & 5 \\
\hline
\end{tabular}




\subsubsection{Conjugação dos transformantes $n i f^{+}$e isolado}

9 com linhagens portadoras de plasmídios con-

\section{tendo transposon}

Cruzamentos envolvendo linhagens de E. coli portadoras de plasmídio com transposon e as fixadoras de $\mathrm{N}_{2}$ 101(9) e isolado 9, foram realizados com o objetivo de se verificar a mobilização de marcas pelo transposon entre estas células. Os cruzamentos, bem como os dados obtidos estão na Tabela 14 .

Somente foram selecionados recombinantes $n$ if e resistentes simultaneamente aos antibióticos canamicina e tetraciclina, o que demonstrou a transferência do plasmídio integralmente para a célula receptora do isolado 9. Desta forma, não se verificou qualquer mobilidade do transposon, o que possibilitaria ocorrência de células resistentes apenas a canamicina, marca conferida pelo transposon. Nos demais experimentos, onde os receptores foram os transforman tes 101(9), não se verificou a transferência dos plasmídios pois as células não apresentaram crescimento em nenhum dos meios contendo antibióticos. 
TABELA 14 - Porcentagem de recombinantes obtidos na conjuga ção entre E. coli portadora de plasmídio com transposon e linhagens fixadoras de $\mathrm{N}_{2}, 101(9) \mathrm{e}$ isolado 9.

Linhagem

Linhagens Receptoras

Doadora

$101(9) 2 \quad 101(9) 4 \quad$ Isolado 9

E. $\operatorname{col} i$

pсBT01/HB 101

0

0

4 


\section{DISCUSSÃo}

Devido à diversidade de assuntos, a discussão dos resultados foi feita agrupando dois tópicos: ocorrência de plasmídios em isolados de bactérias fixadoras de $\mathrm{N}_{2}$ assimbióticas e (2) estudos genéticos da fixação de $\mathrm{N}_{2}$ incluindó experimentos de transformação e conjugação para um dos isolados obtidos.

\subsection{Ocorrência de plasmídios.}

Tem sido verificada a presença de plasmídios em inümeros gêneros de bactērias fixadoras de $\mathrm{N}_{2}$, mas segun do a literatura, o maior nümero encontrado se referem aos gê neros Azospipillum e Rhizobium. ROBSON (1981) observouplas mídios em linhagens de $A$. chroococcum e $A$. paspali, mas nenhum para $A$. vinelandii. Uma das 1 inhagens observadas de $A$. chroococcum continha 5 plasmídios. 
Levando-se em consideração os resultados obtidos através de eletroforeses realizadas nas amostras de bac térias fixadoras de $\mathrm{N}_{2}$ (Figura 2), pode-se observar que pou cas 1 inhagens apresentaram plasmídios: a 2-2II, 5-3 e 40-1, com pesos moleculares de 64,40 e 92 Md, respectivamente. To das as amostras foram submetidas aos dois métodos de eletro forese descritos no item 3.4, sendo que o segundo (item 3.4.2) apresentou bandas plasmidiais mais nitidas devido a menor interferência do DNA cromossomal.

Os isolados selvagens do solo, com exceção do 9, não foram classificados, mas pelo tipo de nutriente em que se desenvolveram, sugere que pertencem aos gêneros AzOtobacter e Beijerinckia. Alguns destes como 74-1, 40-1IV e LAMS, não foram submetidos à eletroforese devido a uma espessa camada de muco que os revestia, dificultando a lise celular e ainda sua manipulação genética por técnicas convencionais. Com relação ao isolado 40-1, o plasmídio somen te foi evidenciado após a amplificação com cloranfenicol. Neste processo de amplificação, o plasmídio continua a replicar independente da replicação cromossômica, e destaforma, o número de cópias por célula aumenta, facilitando a vi sualização eletroforética (CLEWELl, 1972). 0 mesmo tipo de tratamento não funcionou nos casos dos outros isolados, onde nenhum plasmídio foi evidenciado.

Entre as linhagens que apresentaram plasmí- 
dios, não se detectou a presença de genes plasmidiais envol vidos com o processo de fixação de $\mathrm{N}_{2}$. Isso foi comprovado pelo fato de que após a eliminação destes plasmídios com agentes de "cura", estas linhagens continuaram a ter desenvolvimento normal em meio isento de nitrogênio incorporado. Isso está de acordo com os dados obtidos porkENNEDY et a $i$ i (1981) e ROBSON (1981) que também não encontraram relação entre os plasmídios observados nas vārias espécies de Azoto bacter e Beijerinckia, com o processo de fixação de $\mathrm{N}_{2}$.

Uma exceção a estes casos foi observada com a Iinhagem de A. brasilense spl que teve alterada a sua ca pacidade de fíxação de $\mathrm{N}_{2}$, ao perder seu dois plasmídios (125 e $65 \mathrm{Md}$ ), fato este também verificado anteriormentepor LEMOS (1980).

Pode-se observar na Tabela 2 que para estas linhagens estudadas, a maior porcentagem de eliminação de plasmídios foi conseguida através do tratamento com calor (variação de 2,03 a $10,3 \%$ ), seguida do tratamento com brome to de etídio (variação de 1,08 a 5,50\%). Estes dados coincidem com os obtidos por SONTEIN e BALDWIN (1972) e RUBIN e ROSEnBlum (1975) na "cura" de plasmídios contendo genes conferindo resistência a drogas em Staphylococcus aureus. Os tratamentos com acriflavina e acridina laranjaforam menos $\underline{e}$ ficientes, resultando em perdas de plasmídios que variaram de 0,52 a 1,03 e 0,23 a $0,83 \%$, respectivamente. 
A perda de plasmídios pela ação do calor não está bem esclarecida, mas vārias explicações têm sido propostas. De acordo com MAY et alii (1964), a perda de resis tência a tetraciclina e penicilina conferida por genes plas midiais em $S$. aureus foi devida a uma menor taxa de replica ção dos plasmídios a $44^{\circ} \mathrm{C}$ do que a da própria célula; sob essas condições, o nümero destes plasmídeos se torna tão re duzido após algumas horas de crescimento, sendo inclusive herdadas de modo irregular, onde algumas células nem apresentam plasmídios. No entanto, para ASHESHOV (1966), o calor apenas refletiu um aumento na taxa normal de perda expontânea de plasmídios que ocorre em longos períodos de estocagens. ZURKOWSKY (1982), atribui a perda de plasmídios por calor em $R$. trifoliz ao fato de que algumas funções replicativas codificadas por genes plasmidiais são temperatura-sensíveis. Deve ser ainda considerado que no caso de plasmídios multicópias que dependem da polimerase I para sua replicação, pode haver alteração dessa enzima pelo calor, sem prejuizo da replicação cromossômica que dẹende da poli merase III (BRODA, 1979).

o brometo de etídio como é sabido, se intercala entre pares de bases de DNA, interferindo na ação da DNA e RNA polimerase (JOHNSTON e RICHMOND, 1970. 


\subsection{Estudos genéticos no isolado9 (Azotobacter paspali)}

Com a finalidade de se proceder um estudo ge nético visando um melhor conhecimento dos genes envolvidos na fixação de $N_{2}$ em $A$. paspali, fez-se uma série de ensaios, uma vez que nenhum estudo neste sentido foi realizadocom es t a bactéria.

A proposta inicial foi o de se isolar mutantes $n i f^{-}$, já obtidos em outras espēcies de Azotobacter. Pa ra isto, as células foram submetidas à irradiação ultra-vio leta e tratamento com ácido nitroso por 2 e 8 minutos, respectivamente, o que foi considerado eficiente para a indução de mutação, levando-se em conta os dados das curvas de sobrevivência.

Houve dificuldades no isolamento de maior nū mero de mutantes nesta bactéria, o mesmo ocorrendo para värios autores em outras espécies de Azotobacter. SADofF et alii (1979) justificam isto, como sendo devido ao fato de Azotobacter ter grande quantidade de DNA (dez vezes mais do que E. coli), inclusive sugerindo a existência de 40 cópias de cromossomas por célula. No entanto, TERzAGHI (1980a) considera que a maioria destes cromossomas não devem serbio logicamente funcionais. De acordo com PAGE e SADOFF (1976a), a dificuldade de obtenção de mutantes em $A$. vine Zandii se de ve à existência de um sistema de reparo pōs-mutacional efi- 
ciente. Neste trabalho, as dificuldades encontradas podem ser assim justificadas, além de se considerar a difícil manutenção dos mutantes obtidos, pois após algumas repicagens havia reversão do caráter.

Conforme mostram os resultados do item 4.5, foram obtidos 6 e 10 mutantes $n i f^{-}$, respectivamente para os tratamentos com ultra-violeta e ácidonitroso. Deste total, 3 eram mutantes auxotróficos para vitamina $B_{1}$ e timina, o que foi revelado pela auxanografia (item 3.13); 8 sofreram reversão para prototrofia e apenas 5 mantiveram sua condi çãonif ${ }^{-}$, ou seja, incapacidade de fixar nitrogênio. A fre quência de aparecimento de mutantes nif ${ }^{-}$foi baixa, principalmente considerando a necessidade dos experimentos posteriores de transformação a que se destinavam. Deve-se consi derar ainda, a alta taxa de reversão (50\%) encontrada nestas mutações. Para um melhor estudo a respeito destes mutantes $n i f^{-}$haveria necessidade de testes mais precisos, co mo sugerido por BRILL (1976), que incluem ressonância paramagnética ou reação com antissoros específicos, para verifi car se a sua deficiência se relacionou com os componentes I, II ou I e II da nitrogenase.

Posteriormente 1 inhagens mutantes $n i f^{-}$e iso lado 9 foram ensaịdas para a seleção de células resistentes a drogas que pudessem servir como marcadores em experimentos de transformação. Para isto, utilizou-se dos dados 
sobre o nível de resistência a drogas do isolado 9, previamente determinado (Tabela 3 ). Como esta bactéria jā apresentava certa resistência natural à ampicilina, foimaiscon veniente utilizar resistentes para uma maior concentração desta droga $(50 \mu g / m 1)$, apesar de terem sido obtidos mutantes resistentes à tetraciclina ( $2 \mu \mathrm{g} / \mathrm{m} 1)$, cloranfenicol ( 10 $\mu g / m 1)$ e canamicina $(5 \mu g / m 1)$. Alēm disto, foram também se lecionados mutantes $n i f^{-}$resistentes a $50 \mu g / m 1$ de ampicili na, os quais juntamente com células do isolado 9 resistentes, serviram como doadores de DNA em vārios processos de transformação.

\subsubsection{Experimentos de transformação}

Uma série de processos de transformações interespecíficas e intergenéricas foram realizadas, utilizando-se o DNA extraído do isolado 9 ou de mutantes nif- origi nados a partir dele. Estes experimentos tiveram como objetivo, estudar os genes $n i f^{-}$de outras espécies de Azotobacter oriundas de populações selvagens do solo, como é o caso do isolado 9. Processos de transformação envolvendo DNA to tal só foram realizados anteriormente em casos onde tanto a linhagem doadora quanto a receptora eram fixadoras de $\mathrm{N}_{2}$, o que facilitou bastante a ocorrencia de recombinantes. Dos inúmeros casos descritos de transformações intergenéricas, envolvendo 1 inhagens receptoras não fixadoras de $\mathrm{N}_{2}$, foi rea 
lizada a clonagem dos genes nif de Klebsiella em plasmídios amplificadores, os quais foram posteriormente transferidos para E. coli e Salmonelza typhimurium (DIXON et alii, 1976; POSTGATE e KRISHNAPILLAI, 1971 ).

No primeiro processo de transformação realizado envolvendo mutantes nif $^{-}$e DNA do isolado 9 (Tabela6), nota-se que a frequência de transformação foi relativamente alta $\left(2,7 \times 10^{-3} \%\right)$ entre os mutantes $n i f^{-}$, podendo-se infe rir que estes deveriam apresentar mutações simples, facilmente corrigidas pela incorporação de DNA exógeno.

Experimentos deste tipo tambēm foram realiza dos por SEN e SEN (1965) ao transformarem A. vinelandii com DNA de A. chroococcum e vice-versa. Pode-se citar ainda PA GE e von TIGERSTROM (1979) e PAGE e SADOFF (1976a,b) que e s tudaram as melhores condições para ocorrência de transfórma ção em mutantes auxotróficos de $A$. vinelandii. Nestes casos, a porcentagem de transformação variou de $10^{-4}$ a $10^{-6} \%$. Segundo estes autores, para induzir competência em Azotobacter, as células devem estar em fase exponencial, e utili zar o fosfato ao invés de cálcio no meio de transformação. A razão disto é que em células velhas, havendo presença de cálcio no meio, ocorre a formação de maior quantidadede polímeros capsulares, dificultando a penetração do DNA transformante. Melhores condições para eliminação de polímeros capsulares tambēm foram avaliadas para a transformação de 
Diplococcus pneumoniae e Bacilzus Zicheniformis por LEONARD e MAttheis (1965) e RAVIN (1957), citado por PAge e SADOFF (1976). YOUNG e SPIZIZEN (1963) também acresecentaram fosfato ao meıo, para melhor absorção do DNA transformante em B. subtilis.

De acordo com WISE et alii (1973) e RICKEN BERG (1974), a adição de 3,5-adenosina cíclica monofosfato (cAMP), induziu competência em $A$. vinelandii ao nível de transcrição, sugerindo um controle de repressão catabólica inclusive entre mutantes nif ${ }^{-}$.

Ainda com relação ao processo de transformação, OPPHEIM e MARCUS (1970) e MARCUS e KANESHIRO (1972) propõem que as células devem crescer em meio contendo nitro gênio incorporado, pois isto provoca alterações na composição e estrutura da membrana celular, facilitando a penetraৎ̧ão do DNA.

Em todos os experimentos de transformação des critos na literatura envolvendo Azotobacter, o DNA de células doadoras foi obtido de 1 isados celulares, sem que tives se sido feito qualquer purificação, gerando inümeras contro vérsias nos resultados. Neste trabalho, fez-se uma modificação de todos estes procedimentos, utilizando-se DNA purificado, conforme descrito no item 3.15 .

Numa tentativa de se localizar as mutações 
$n i f^{-}\left(n i f_{1}^{-}\right.$a $\left.n i f_{5}^{-}\right)$no genoma do isolado 9 , fez-se o cruza mento dos diferentes mutantes com DNA extraído de linhagens nif ${ }^{-}$, conforme mostram os dados da Tabela 7. Pela frequência de transformantes obtidos nos diferentes cruzamentos, pode-se observar que praticamente nenhum transformante foi de tectado quando as mutações $n i f^{-}$carregadas pela 1 inhagem do adora e receptora foram as mesmas.

Como é sabido, a distância entre dois genes é diretamente proporcional à frequência de recombinação, ou seja, valores de recombinação altos em determinado cruzamen to indicam que a distância entre os genes é relativamente grande (LACKS e HOTCHKISS, 1960 ; EPHRATI-ELIZUR etalii, 1961 ; BISHOP e BRILL, 1977). Pode-se notar pelos dados que os mu tantes $n i f_{1}^{-}$e $n i f_{5}^{-}$provavelmente apresentam o mesmo tipo de mutação, pois não se detectou transformantes entre eles; mu tantes $n i f_{2}^{-}$e $n i f_{3}^{-}$devem estar bem próximos, pois apresenta ram uma frequência de recombinação muito baixa.

Foram obtidas diferentes frequências de trans formação entre as linhagens mutantes, isto devido, em parte ao tamanho do segmento de DNA envolvido. No entanto, em qualquer frequência, esta variação entre as linhagens indicou que as mutações não foram idênticas, pelo menos na maio ria dos casos.

Nota-se que a frequência de transformantes 
nif $f^{+}$obtidos com DNA mutante (Tabela 7) foi consideravelmen te menor do que com o DNA da 1 inhagem selvagem (Tabela 6). os valores de recombinação dão uma estimativa da distância entre os genes nif e a partir desses dados, pode-se estabelecer a posição das mutações nif envolvendo A. paspali (Figura 7). Alguns valores discrepantes são observados entre os cruzamentos recíprocos, decorrentes da própria metodologia empregada, mas apesar disto, os dados sugerem que pelo menos três mutações diferentes estão relacionadas ( $i_{i}^{*} 2,3$ e 5) e que $n i f^{-} 4$ deve estar mais distante deste grupo.

A marca para resistência a ampicilina permaneceu em apenas dois cruzamentos envolvendo nif 4 (nif $^{-} 4 \mathrm{x}$ $n i f^{-} 5$ e $\left.n i f^{-} 4 \times n i f^{-} 1\right)$, conforme mencionado anteriormente, o que leva a pensar em 1 igação com $n i f^{-} 4$. De acordo com LACKS e HOTCHKISS (1960), é conveniente o uso de umamar ca de resistência em experimentos deste tipo, pois permite uma medida da frequência de transformação, independenté de variações ocasionadas pelo uso de várias culturas receptoras, competência individual de cada uma delas ou uso de DNA em concentrações diferentes. No entanto, o aparecimento da marca de resistência em apenas dois cruzamentos, não permitiu que todas estas interferências citadas, fossem eliminadas .

Para melhor conhecimento a respeito da loca1 ização dos genes nif nesta bactēria, haveria necessidade 
de se trabalhar com maior nümero de mutantes, cuja obtenção não foi possível. BISHOP e BRILL (1977) em experimento semelhante com $A$. vinelandii, não conseguiram estabelecer posições bem definidas para as mutações nif, apesar de utilizar maior número de mutantes.

Entretanto, deve-se ressaltar, que hä certas dificuldades na utilização do método de transformação para se fazer mapeamento, pois o pedaço de DNA envolvido é peque no e assim não é tão simples mostrar que dois genes são 1 igados, mesmo quando grande nümero de mutações são analisadas .

Foram obtidos resultados surpreendentes neste trabalho, quando se realizou a transformação intergenéri ca entre 1 inhagens de.E. coli com DNA de A. paspali. Como pode ser notado através dos dados da Tabela 8, obteve-se a guns transformantes, quando as 1 inhagens receptoras foram HB101, C600 e R1drd19. No entanto, ao se confirmar o crescimento em meio isento de nitrogênio, apenas algumas colônias de HBlOl e CA77 mantiveram a condição nif ${ }^{+}$. Nas demais a recombinação foi instável, não se mantendo nas geraçoes seguintes. Na literatura tambēm hä citações de transformações intergenēricas entre fixadores de $\mathrm{N}_{2}$, onde DNA de espé cies de Rhizobium foi transferido para linhagens de $A$. vine

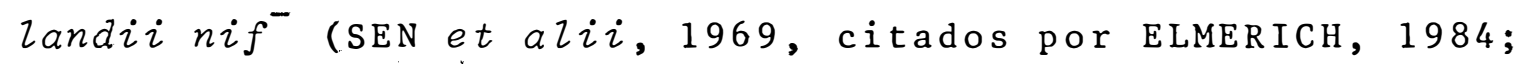
MAIER et alii, 1978). 
Convēm salientar que a linhagem HB101, da mes ma forma que a C600, é desprovida de mecanismos de restrição e modificação, mas devido a mutação pérdeu a capacidade de recombinação ao nível cromossômico (rec ${ }^{-}$). Hā suspeitas de que esta linhagem perdeu a característica rec ${ }^{-}$durante a estocagem, uma vez que utilizando-se esta mesmabactériapro veniente de outro laboratório, não se conseguiu os mesmos transformantes $n i f^{+}$. Além disto, também foram perdidas as marcas auxotróficas $B_{1}$ (incapacidade de produzir vitamina $\mathrm{B}_{1}$ ) e $\mathrm{lac}^{-}$(não utilização da lactose como fonte de carbono), confirmadas experimentalmente. No entanto, as demais marcas auxotróficas leucina e prolina, além das características culturais e morfológicas permaneceraminalteradas quan do comparadas com a outra linhagem, o que afasta a possibilidade de ser um contaminante.

Estes fatos demonstram que hä possibilidades reais de que tenha ocorrido recombinantes $n i f^{+}$de E. coli HB 101 , a partir da transformação com DNA total dabactéria fixadora. Por outro lado, não se obteve transformantes nif $f^{+}$s täveis da linhagem de E. coli C600, apesar das boas carac terísticas apresentadas pelas células receptoras. Segundo OISHI e COSLOY (1974) e WACKERNAGEL (1973), a transformação de E. coli com DNA exógeno é possível com 1 inhagens que perderam a enzima exonuclease, devido a mutação em rec B ou C, mas a capacidade de recombinação foi recuperada através 
de uma supressão. Além disto, estes autores afirmam que a absorção de DNA é facilitada pelo tratamento das células re ceptoras em $\mathrm{CaCl}_{2}$. Deve ser ressaltado que a frequência de transformação de $E$. coli nos experimentos realizados, foi muito baixa, principalmente quando comparada com a obtida em cruzamentos interespecíficos (Tabela 6).

os transformantes apresentaram capacidade de fixar $N_{2}$ na presença de oxigênio, da mesma forma que Azotobacter. Como jā citado anteriormente, Azotobacter possui um eficiente sistema de proteção da nitrogenase, umavez que fixa $\mathrm{N}_{2}$ em presença de oxigênio, ao contrārio de KZebsiella (anaerobiose) ou Azospirizlum (microaerófi1o)(BRILL, 1980). São perfeitamente compreensíveis os trabalhos descritos na 1iteratura a respeito da transferência de genes nif para 1 inhagens mutantes $n i f^{-}$, onde há expressão do caráter, mesmo em presença de oxigênio. Na maioria destes casos, as linha gens receptoras são $n i f^{-}$, mas possuem todo um sistema intac to de proteção da nitrogenase. No entanto, para que seja possível a expressão da condição $n i f^{+}$em células receptoras originalmente não fixadoras de $\mathrm{N}_{2}$, é necessārio que estas recebam por transformação, também os genes envolvidos com o sistema de proteção da nitrogenase. Entretanto,jáfoi cons tatado por CANNON (1976), a transferência do plasmídio RP41 com parte dos genes nif de Klebsiella para Azotobacter, onde os genes niftambém se expressaram, mesmo em aerobiose. 
Através da anālise dos resultados de transformação, värias considerações podem ser feitas. o fato de se ter conseguido transformantes $n i f^{t}$ de $E$. coli através do uso direto de DNA extraido de $A$. paspali leva a propor a hi pótese de que os genes nif, nesta bactéria ou pelomenos par te deles, está em um único grupo, da mesma forma que em KZebsielza (ROBERTS e BRILL, 1981), possibilitando sua transfe rência através de um único segmento de DNA. Embora as posi ções dos genes nif em Azotobacter não estejam bem definidas, a anālise de mutantes $n i f^{-}$indicou que em $A$. vine Zandii, estes não estão todos num mesmo grupo, sendo o mesmo constatado com A. paspali neste trabalho. Isso dificultaria a ocorrência de transformantes $n i f^{+}$em bactérias recepto ras não fixadoras, comó o caso de $E$. coli, uma vez que pa ra a expressão do fenótipo em estudo, haveria necessidade da transferência de todo o grupo nif. Esta ü1tima observação não invalida a primeira hipótese pelos fatos já expostos nesta discussão, de que mesmo parte do segmento com genes nif de Klebsiezza jā se expressaram em $E$. coli. De acordo com STREICHER et alii (1972), há possibilidade demais genes estarem relacionados com a fixação de $\mathrm{N}_{2}$ em Klebsielza. Isto foi proposto pelo fato de que alguns mutantes não recombinaram com a marca his, apesar de ter sido comprovado que o grupo nif nesta bactéria estā próximo ao operon his. 
CHARD (1965) conseguiram a transferência de marcas distantes em B. subtilis ao utilizarem DNA de alto peso molecu1ar. Assim, pode-se inferir que a ocorrência destes transformantes seriam resultado da transferência de marcas nãomui to próximas ou que apenas parte do grupo nif de A. paspali já foi suficiente para que o fenótipo $n i f^{+}$se manifestasse. De qualquer forma, os resultados de transformação obtidos neste trabalho com a finalidade de mapear a região nif, não podem ser considerados conclusivos, visto que o nümerodemu tantes analisados foi pequeno.

Apesar de $A$. vinelandi $i$ ser bem estudada, mui tos detalhes necessitam ser conhecidos a respeito da posi ção dos genes nif no seu genoma, tendo sido demonstrado por BISHOP et alii $(1980,1982)$ a existência de um sistema alter nativo de fixação de $\mathrm{N}_{2}$ nestes organismos. Além disto, em trabalhos recentes, RUVKUN e AUSUBEL (1980) demonstraramque plasmídios contendo genes nif de Klebsiellahibridizaramcom cinco diferentes fragmentos de DNA de A. vinelandii. Uma anālise destes resultados leva a concluir que hämais do que uma região do cromossoma desta bactéria que contém homologia com Klebsielza. Provavelmente estas vārias regiões de homologia correspondem a dois sistemas diferentes de fixa ção de $\mathrm{N}_{2}$.

As Tabelas 10 e 11 mostram que apesar dos transformantes $n i f^{+}$de $E$. coli, se desenvolverem em meio i- 
sento de nitrogênio incorporado, a taxa de crescimento foi bem menor quando comparada com a linhagem original doadora. Em meio contendo nitrogênio incorporado, os transformantes tambēm apresentaram menor crescimento que a prōpria 1 inhagem HB101. Mas nenhuma diferença significativa foi observa da na taxa de crescimento entre os transformantes, em qua 1quer dos meios considerados.

são värias as evidências indicando que os transformantes sejam realmente a bactéria E. coli, principalmente características morfológicas e fisiológicas. A di mensão das células bacterianas foi ligeiramente menor quando comparada com a linhagem original receptora. Esta alteração na dimensão celular não foi significativa em relação às diferenças encontradas por SEN e SEN (1965) ao fazerem transformações entre A. vinelandii e A. chroococcum. observaram que quando $A$. chroococcum foi transformada com DNA de A. vinelandii, as colônias transformantes diferiram da Iinhagem original em cor, diâmetro e características bioquími cas. Alguns destes transformantes tinham ainda maior efici ência de fixação de $\mathrm{N}_{2}$ do que a linhagem receptora. o mesmo foi observado quando a linhagem receptora foi $A$. vinelan di $i$ diferindo apenas no decréscimo da atividade de fixação de $\mathrm{N}_{2} \cdot$

Dados coincidentes com a reduzida taxa de crescimento foram encontrados ao se avaliar a atividade da 
nitrogenase nos transformantes, medida pela redução do acetileno. Observando-se os dados da Tabela 9 , nota-se que a quantidade de nitrogenase nas amostras de transformantes foi muito pequena, em comparação com a linhagem do isolado 9 riginal. Foram testadas várias condições decrescimento das amostras, tais como incubação em ambiente com e sem oxigênio, tempo de incubação, etc, visando uma maior produção de nitrogenase. Os resultados apresentados na Tabela 9 foram os melhores conseguidos em todas as situações examinadas. A pos a colocação do gás acetileno, houve a necessidade de se in cubar as amostras durante 24 horas, antes de se fazer a medida de etileno no cromatógrafo. Isto foi necessário por que a quantidade de nitrogenase presente nas amostras era muito pequena, ao nível do 1 imite de sensibilidade do apare 1ho. Um estudo mais detalhado destes transformantes seria interessante futuramente, no sentido de se utilizar outras técnicas para detecção individual da atividade dos componen tes I e II da nitrogenase.

Nenhum transformante foi obtido quando as cé lulas receptoras foram da levedura $S$. cerevisiae, o que já era esperado, pois não houve expressão nem mesmo quando os 17 genes nif de Klebsielza clonados em plasmídios foram introduzidos nessa levedura (ALADAR et ali $i$, citados por BRILL, 1981). Segundo estes autores, embora não tenha ocorrido expressão da condição $n i f^{+}$, o experimento demonstrou que 
pode haver transferência entre procariotos e eucariotos, res saltando ainda que o insucesso também foi devido à complexa transferência de características codificadas por vários genes, como é a fixação de $\mathrm{N}_{2}$. Neste caso, o DNA deveria ser primeiramente transcrito corretamente em RA pelas leveduras, interpretando os sinais bacterianos para o inícioefinal da transcrição. Em seguida, ser reconhecido pelos ribossomas como sendo mensageiro, para sua posterior tradução em proteína. Assim, para expressão da condiçãonif $f^{+}$, as 17 proteínas deveriam então atuar juntas no citoplasma estranho da célula de levedura, havendo provavelmente certas res trições para isto. Uma das hipóteses para esta dificuldade é que a molécula de nitrogenase exige em sua estrutura gran de nümero de átomos de ferro, mas não é certeza que a levedura disponha deste requerimento, sem haver prejuízoda síntese de outras enzimas essenciais.

Recombinação entre levedura e bactéria também jā foi realizada por BEGGS (1978), onde células de $S$. cerevisiae foram transformadas com o plasmídio pMB9 (deriva do de colel de $E$. coli), carregando o gene Leu 2 de levedura e resistência à tetraciclina conferida por gene bacteria no. Neste caso, foram obtidos com alta frequência transformantes de levedura $1 \mathrm{lu}^{+}$e resistentes à tetraciclina,mos trando que leveduras podem ser transformadas por plasmídios híbridos. A análise de tétrades de transformantes obtidos 
com pJDB219 e pJDB248, derivados de pMB9, mostraram que os plasmídios híbridos mantiveram-se extracromossomicamente na célula de levedura.

Diante do exposto, novas tentativas de trans ferência dos genes nif para leveduras devem ser feitas,pois estas são organismos facilmente propagáveis e sua semelhança bioquímica e fisiolögica com bactérias permite o uso de técnicas desenvolvidas para sistemas bacterianos. Além dis to, oferecem vantagens para estudos genéticos pela possibilidade de se apresentar nos estados haplóide ediplóide. Pạ ra os pesquisadores mais otimistas que julgam ser possível transferir no.futuro os genes nif para plantas superiores, um dos passos intermediários seria uma melhor compreensãoda recombinação entre genes de procariotos e eucariotos mais simples, como é o caso das leveduras.

\subsubsection{Experimentos de conjugação}

os transformantes nif foram utilizados em vārios experimentos de conjugação com 1 inhagens de $E$. coli, a fim de se verificar uma possível transferência dos genes nif para estas bactérias. Inicialmente, os transformantes $101(9) 1$ a 6 serviram como células receptoras para os plasmí dios carregados pelas 1 inhagens $S a$ e Rldrdig, contendo marcas de resistência a drogas. A 1 inhagem CA77 amp ${ }^{\text {R }}$ (Hfr)tam- 
bém foi utilizada como doadora. Pode-se notar pelos dados da Tabela 12, que em alguns casos houve transferência do plas mídio para os transformantes, principalmente quando a 1 inhagem doadora foi a Rldrd19. Desta forma, os transformantes continuaram a fixar $\mathrm{N}_{2}$, apresentando ainda resistência as drogas cloranfenicol e ampicilina, conferida pela aquisição do plasmídio da célula doadora. Apenas um caso de recombinação ocorreu quando a linhagem doadora foi a portadora do plasmídio Sa, onde foram selecionadas algumas colônias ( $\mathrm{Sa}$ / $101(9) 2$ ) que apresentaram crescimento em meio contendo cloranfenicol, sem adição defontes de nitrogênio. Nos casos onde se constatou a transferência dos plasmídios pela aquisição de resistência a drogas, fez-se a confirmação através de eletroforese em gel de agarose. Desta forma, comprovouse a presença dos plașídios, pela banda eletroforética similar a encontrada nas 1 inhagens doadoras.

o fato de ter ocorrido conjugação, não impli ca obrigatoriamente que doadoras e receptoras sejam da mesma espëcie. Segundo BERINGER (1982), hä possibilidade de conjugação entre diferentes espēcies de bactērias Gram nega tivas. No entanto, os dados de conjugação obtidos reforçam os resultados de transformação entre A. paspali e E. coli.

os transformantes $n i f^{+}$e resistentes a drogas, foram posteriormente conjugados com linhagens $\mathrm{F}^{-}$de $E$. coli, como 6600 e 711 , para se verificara possibilidade dos 
genes nif terem se incorporado aos plasmídios. Assim, pode ria ter-se construído um plasmídio com genes para resistência e fixação de $\mathrm{N}_{2}$, facilmente transferível para outras $1 \underline{i}$ nhagens receptoras. A linhagem HB101 não foi utilizadacomo receptora neste cruzamento, pois haveria dificuldade na comprovação da transferência do plasmídio, uma vez que as marcas auxotróficas carregadas pelas linhagens doadoras e re ceptoras seriam as mesmas. Conforme mostram os dados obtidos no item 4.8.1, os plasmídios foram transferidos para as linhagens receptoras, conferindo resistência a drogas antes não apresentada. Contudo, a incapacidade de fixar $\mathrm{N}_{2}$, permaneceu inalterada nas 1 inhagens receptoras, onde se concluiu que os plasmídios não mobilizaram genes nif cromossomais, na transferência para outras células. De acordo com BERINGER (1982), os plasmídios podem mobilizar fragmentos de DNA cromossômico durante a conjugação, fato que não ocor reu nestes experimentos.

Vārias tentativas foram feitas no sentido de se obter uma 1 inhagem transformante de $E$. coli $n i f^{+}$doadora, capaz de transferir estes genes para células receptoras. Os experimentos apresentados nos itens 4.6 .3 e 4.8 .1 , onde respectivamente, a 1 inhagem $C A 77$ foi transformada com DNA do solado 9 e a CA77 amp foi conjugada com cada um dos transformantes $101(9)$, são exemplos disto. Em ambos os casos, obteve-se alguns recombinantes em baixa frequência, mas foi 
impossível a transferência dos genes nif através da conjuga ção com células receptoras. Isto leva a pensar que os genes nif não se incorporaram ao genoma da linhagem Hfr.

Os dados da Tabela 13 mostram a conjugação entre diferentes transformantes $n i f^{+}$numa tentativa de melhorar a eficiência da nitrogenase. Partindo-se do princípio que cada transformante carregava diferentes segmentos nif, poderia haver complementação através do cruzamento entre eles. Assim, após o cruzamento,foram selecionadas as co lônias de maior tamanho desenvolvidas em meio sem nitrogênio, o que de certa forma, demonstrou maior eficiência de fi xação de $\mathrm{N}_{2}$.

0 fato de não ter havido aumento significati vo na atividade da nitrogenase, conforme demonstram os dados da redução do acetileno, faz supor que os transforman tes devem carregar o mesmo segmento nif, ou mais provave1mente, a linhagem CA77/101(9)2, não se comportou como doado ra. Prova a favor desta ültima hipótese foi dada quando se tentou a conjugação desta provável doadora com outras linha gens $\mathrm{F}^{-}(\mathrm{C} 600,711)$ e nada se conseguiu em termos de transferência dos genes nif.

Os cruzamentos envolvendo a 1 inhagem de $E$. coli pcBTol/HBlol, portadora do plasmídio, com o transposon Tn5 ( $\left.c^{R} A^{R}{ }^{R}\right)$, foram feitos para verificar a mobilização 
destes nas linhagens receptoras. Conforme já citado na des crição das linhagens (Tabela 1), a resistência à tetracicli na e canamicina nesta bactéria, são conferidas respectivamente, por gene plasmidial e pelo Tn5 introduzidonesteplas mídio. Os dados da Tabela 14 mostram que nao se conseguiu a transferência do plasmídio nos casos ondé as células receptoras foram os transformantes $n i f^{+}$, porém isto foi_possí vel quando a receptora foi o próprio isolado 9. No entanto, apōs vārias gerações, esta condição não foi mantida, possivelmente pela perda do plasmídio pois não houve crescimento dos recombinantes, nem em meio contendo apenas tetraciclina. Foram feitas vārias combinações de meios de cultura acresci do dos antibióticos tetraciclina e canamicina (item 3.19.4), para se observar a mobilização de marcas pelo transposon.

$$
\text { BERG et a } i \text { i (1975) e BERINGER et a } i \text { i (1978) }
$$
conseguiram a transferência de um plasmídio de $E$. coli contendo Tn5, resistente a canamicina, para Rhizobium legumino sarum (frequência de $10^{-6} \%$ ), onde este se inseriu no cromos soma da bactéria receptora.

A partir destas observações, nota-se que é pos sível a existência de um sistema diferente de fixação de $\mathrm{N}_{2}$ no isolado 9 (A. paspali) em estudo, pois alēm da espécie não ter sido anteriormente estudada geneticamente, deve-se considerar que esta foi isolada diretamente do solo, podendo apresentar características prōprias, ao conträrio de ou- 
tras culturas pertencentes a coleções e jā bem caracterizadas. De qualquer forma, para resultados mais conclusivos há necessidade de outros experimentos genéticos e mesmo bioquímicos, pois todas estas especulações são apenas hipóteses. Em termos genéticos, o sistema aqui estudado merece destaque, pois abre novas perspectivas para experimentos fu turos, onde estes genes nif poderão ser melhor mapeados com a utilização de maior número de mutantes, ou ainda com a utilização de transdução. Para isto, haveria necessidade de deteç̧ão de fagos específicos, fato que nãofoi verificado neste trabalho, mas comprovados para outras espécies de $A-$ zotobacter. Se realmente estas considerações forem válidas, tem-se aqui um sistema ideal para transferir genes nif para outras bactérias não fixadoras típicas de solo, seja por transformação ou mesmo através da clonagemem plasmídios amplificadores. De acordo com HELINSKI (1977), plasmídios de E. coli contendo genes nif de Klebsiella clonados podem ser transferidos. para outras bactérias Gram negativas, mas não se mantém estável quando as receptoras não são relacionadas filogeneticamente. Sendo assim, o uso destes plasmídios é 1 i. mitado na agricultura para bactérias não relacionadas com a E. coli. Resultados práticos, visando o aumento da produtividade em gramíneas normalmente associadas com $A$. paspali em es tudo, levam a pensarde imediato no aumento da capacidade de fixar $\mathrm{N}_{2}$ atmosférico às custas de manipulação genética, devido a um incremento da produção de nitrogenase. 


\section{CONCLUSÕES}

0 estudo de genes envolvidos com o processo de fixação assimbiótica de $\mathrm{N}_{2}$, em populações selvagens do só 1o, forneceu resultados que permitem tirar as seguintes con clusões:

(1) Dentre os isolados bacterianos que apresentaram plasmídios, não se detectou a presença de genes plasmidiais relacionados com o processo de fixação de $\mathrm{N}_{2}$.

(2) Foi possível efetuar testes de complemen taçao utilizando-se transformação com DNA total entre mutan tes $n i f^{-}$do-isolado 9 , verificando-se que alguns genes nif estão próximos ao longo do cromossoma bacteriano.

(3) A obtenção de transformantes $n i f^{+}$de $E$. coli capazes de fixar $\mathrm{N}_{2}$ em aerobiose, mas produzindo baixa atividade de nitrogenase, demonstrou que a maioriados genes 
nif funcionais estão em um grupo capaz de ser transferido num único segmento de DNA. Isto permite considerar a hipótese de um sistema alternativo de fixação de $\mathrm{N}_{2}$ em Az̧otobac ter, como propõem alguns autores.

(4) Não se obteve transformantes $n i f^{+}$quando a linhagem receptora foi a levedura $S$. cerevisiae, mostrando que ainda há grandes restrições na transferência de mate rial genético entre procariotos e eucariotos.

(5) Devido a metodologia usada, reparo pósmutacional ou instabilidade genética, não foi possível manter grande nūmero de mutantes ( $i^{-}$ou'auxotróficos) e trans formantes $n i f^{+}$a partir do isolado 9 .

(6) A transferência de marcas de resistência de E. coli para os transformantes, demonstrou que não ocorreram barreiras para a transferência de material genético en tre estas 1 inhagens.

(7) Pode-se sugerir a hipótese da existência de sistemas fixadores de $\mathrm{N}_{2}$ diferentes daqueles jä verifi cados para outras bactérias do gênero Azotobacter.

(8) 0 isolado selvagem 9 de $A$. paspali abre novas perspectivas no sentido aplicado, pois através de sua manipulação genética pode ser conseguido um aumento da pro- 
dutividade em nitrogênio fixável para as gramineas às quais estas bactérias estão frequentemente associadas.

(9) Pode ser possível a transferência do seg. mento nif por transformação, para outras bactérias não fixa doras típicas de solo, da mesma forma que foi possível para E. coli。 


\section{LITERATURA CITADA}

ASHESHOV, E.H., 1966. Loss of antibiotic resistance in Staphylococcus aureus resulting from growth at higher temperature. Journal of General Microbiology. London, $42: 403-410$.

AUSUBEL, F.M., 1980. Ap'plication of recombinant DNA technology to the study of nitrogen fixation. In: SUBBA RAO, N.S., Ed. Recent advances in biological nitrogen fixation. Edward Arnold, London, p. 257-280.

BANFALVI, Z.; V. SAKANYAN; C. KONCZ; A. KISS; I. DUSHA e A. KONDOROSI, 1981. Location of nodulation and nitrogen fixation genes on a high molecular weight plasmid of Rhizobium melizoti. Molecular and General Genetics. Berlin, 184: 318-325. 
BAREA, J.M. e M.E. BROWN, 1975. Effects on plant growth produced by Azotobacter paspali related to synthesis of plant growth regulating substances. Journal Applied Bacteriology. Reading, $\quad 37(4): 583-593$.

BECKING, J.H., 1962. Species differences in molybdenum and vanadium requirements and combined nitrogen utilization by Azotobacteriaceae. Plant and Soil. The Hague, 16: 171-201.

BEGGS, J.D., 1978. Transformation of yeast by a replicating hybrid plasmid. Nature. London, $275: 104-109$.

BENEMANN, J.R. e R.C. VALENTINE, 1972. The pathways of nitrogen fixation. Advances in Microbial Physiology. London, 8: 59-98.

BENSON, D.R.; D.J. ARP e R.H. BURRIS, 1979. Ce11-free nitrogenase and hydrogenase from actinorhizal root nodules. Science. New York, 205: 688-689,

BERG, D.E.; J. DAVIES; B. ALLET e J.D. ROCHAIX, 1975 . Transposition of $R$ factor genes to bacteriophage $\lambda$. Proceedings of the National Academy of Sciences. Washington, $72: 3628-3632$ 。 
BERINGER, J.; J.L. BEYNON; A.V. BUCHANAN-VOLLASTON e A.W.B. JOHNSTON, 1978. Transfer of the drug-resistance transposon Tn5 to Rhizobium. Nature. London, 275:633634.

BERNDT, H.; K.P. OSTWAL; J. LALUCAT; C. SCHUMANN; F. MAYER e H.G. SCHLEGEL, 1976. Identification and physiological characterization of the nitrogen fixing bacterium Corynebacterium autotrophicum. Archive of Microbiology. Berlin, 108: 17-26.

BEYNON, J.L.; J.E. BERINGER e A.W.B. JOHNSTON, 1980.

Plasmids and host range in Rhizobium leguminosarum and Rhizobium phaseoli. Journal of General Microbiology. London, 120: 421-429.

BIGGINS, D.R.; M. KELly e J.R. POSTGATE, 1971. Resolution of nitrogenase of Mycobacterium flavum 301 into two components and cross reaction with nitrogenase components from other bacteria. European Journal Biochemistry. Berlin, 20: 140-143.

BISHOP, P.E. e W.J. BRILL, 1977. Genetic analysis of Azotobacter vinelandii mutants strains unable to fix nitrogen. Journal of Bacteriology. Baltimore, 130: $954-956$. 
BISHOP, P.E.; F.B. DAZZO; E.R. APPELBAUM; R.J. MAIER e W.J. BRILL, 1977a. Intergeneric transfer of genes involved in the Rhizobium legumes symbiosis. Science. New York, $198: 938-940$.

BISHOP, P.E.; D.M.L. JARLENSKI e D.R. HETHERINGTON, 1980 . Evidence for an alternative nitrogen fixation system in Azotobacter vinelandii. Proceedings of the National Academy of Sciences. Washington, 77: 7342-7346.

BISHOP, P.E.; D.M.L. JARLENSKI e D.R. HETHERINGTON, 1982 . Expression of an alternative nitrogen fixation system in Azotobacter vinelandii. Journal of Bacteriology. USA, 150: 1244-1251.

BISHOP, P.E.; M.A. SUPIANO e W.J. BRILL, 1977b. Technique for isolating phage for Azotobacter vinelandii. Applied Environmental Microbiology. Washington, 23: 1007-1008.

BODDEY, R.M.; P.M. CHALK; R.L. VICTORIA; E: MATSUI e J. DOBEREINER, 1983. The use of the ${ }^{15} \mathrm{~N}$ isotope diluition technique to estimate the contribuition of associated biological nitrogen fixation to the nitrogen nutrition of Paspalum notatum. Canadian Journal Microbiology. otawa, 29: 1036-1045. 
BOVANCHAUD, D.H.; M.R. SCAVIZZI e Y.A. CHABBERT, 1969.

Elimination by ethidium bromide of antibiotic resistance in enterobacteria and staphylococci. Journal of General Microbiology. London, 54: 417-425.

BRADLEY, D.E., 1967. Ultrastructure of bacteriophages and bacteriocins. Bacteriological Reviews, 31: 230-314.

BREED, R.S.; E.G.D. MURRAY e N. SMITH, 1974. - Bergey's manual of determinative bacteriology. Williams e Wilkins Company, Baltimore.

BREWIN, N.J.; J.E. BERINGER; A.V. BUCHANAN-WOLLASTON; A.W.B . JOHNSTON e P.R. HIRSCH, 1980. Transfer of symbiotic genes with bacteriocinogenic plasmids in Rhizobium Ieguminosarum. Journal of General Microbiology. Eondon, $116: 261-270$.

BRILL, W.J., 1976. Control of nitrogenase synthesis in Azotobacter vinelandii. In: NUTMAN, P.S., Ed., Symbiotic nitrogen fixation in plants. Cambridge University Press. p. $39-47$.

BRILL, W.J., 1977. Biological nitrogen fixation. Scientifican American. New York, 236: 68-81. 
BRILL, W.J., 1980. Biochemical genetics of nitrogen fixation. Microbiological Reviews. New York, 44: 449-467.

BRILL, W.J., 1981. Agricultural microbiology. Scientifican American. New York, 245: 199-215.

BRILL, W.J.; J. WESTPHAL; M. STIEGHORST; L.C. DAVIS e V.K. SHAH, 1974. Detection of nitrogenase components and other nonheme iron proteins in polyacrylamide gels. Analytical Biochemistry. New York, 60: 237-241.

BRODA, P., 1979. Plasmids. W. H. Freeman and Company. $0 \times$ ford. $188 \mathrm{p}$.

BROWN, M.E., 1976. Role of Azotobacter paspali in association with Paspalum notatum. Journal Applied Bacteriology. England, 40:341-348.

BUCHANAN-WOLLASTON, V.; M.C. CANNON; J.L. BEYNON e F.C. CANNON, 1980. Role of nif $A$ gene product in the regulation of nif expression in Klebsiella pneumoniae. Nature. London, 294: 776-778.

BULEN, W.A.; R.C. BURNS e J.R. LeCOMTE, 1964. Nitrogen fixation: cell-free system with extracts of Azotobacter. Biochemical and Biophysical Research Communications. 
New York, 17: 265-271.

BULEN, W.A. e J.R. LECOMTE, 1962. Isolation and properties of a yellow green fluorescent peptide from Azotobacter medium. Biochemical and Biophysical Research Communications. New York, 9: 523-528.

BULEN, W.A. e J.R. LECOMTE, 1966. The nitrogenase system from Azotobacter: two enzyme requirement for $\mathrm{N}_{2}$ reduction, ATP dependent $\mathrm{H}_{2}$ evolution, and ATP hydrolysis. Proceedings of the National Academy of Science. Washington, 56: $979-986$.

BUNS, R.C..; R.D. HOLSTEN e R.W.F. HARDY, 1970. Isolation and cristallization of the Mofe protein of Azotobacter nitrogenase. Biochemical and Biophysical Research Communications. New York, 39: 90-99.

BUSH, J.A. e P.W. WILSON, 1959. A non-gummy chromogenic strain of Azotobacter vinelandii. Journal of Bacteriology. Baltimore, 184: 381 .

CANNON, F.C. e J.R. POSTGATE, 1976. Expression of Klebsielza nitrogen fixation genes ( $n i f$ ) in Azotobacter. Nature. London, 260: 271-272. 
CANNON, F.C.; G.E. RIEDEL e F.M. AUSUBEL, 1977. Recombinant plasmid that carries part of the nitrogen fixation (nif) gene cluster of Klebsiella pneumoniae. Proceedings of the National Academy of Sciences. USA, 74: 2963-2967.

CASSE, F.; C. BOUCHER; J.S. JULLIOT; M. MICHEL e J. DENARIE, 1979. Identification and characterization of large plasmids in Rhizobium melizoti using agarose gel electrophoresis. Journal of General Microbiology. Great Britain, 113: 229-242.

CHEN, J.S.; J.S. MULTANI e L.E. MORTENSON, 1973. Structural investigation of nitrogenase components from Clostriäium pasteurianum and comparison with similar components of other organisms. Biochimica et Biophysica Acta. New York, 310: 51-59.

CHUML, V.A.; B.J. THOMPSON; B.L. SMILEY e R.C. WARNER, 1960 . Properties of Azotobacter phage PAV-1 and its DNA. Virology. New York, 102: 262-266.

CLEWELL, D.B., 1972. Nature of Col E1 plasmid replication in Escherichia coli in the presence of chloramphenicol. Journal of Bacteriology. Baltimore, 110: 667-676.

COHEN, S.N.; A.C.Y. CHANG e L. HUE, 1972. Non chromosomal 
antibiotic resistance in bacteria: genetic transformation of Escherichia coli by R-factor DNA. Proceedings of the National Academy of Science. Washington, 69: 2110-2114.

CORBIN, L. e W.A. BULEN, 1969. The isolation and identification of 2,3-dihydroxybenzoic acid and 2-N, 6-N-di-(2,3-dihydroxy-benzoyl)-L-1ysine formed by irondeficient Azotobacter vinelandii. Biochemistry. New York, 8: 757-762.

DALTON, H. e J.R. POSTGATE, 1969. Effect of oxygen on growth of Azotobacter chroococcum in batch and continuous cultures. Journal of General Microbiology. Lond on, 54: 463-473.

DALTON, H. e J.R. POSTGATE, 1969. Growth and physiology of Azotobacter chroococcum in continuous culture. Journal of General Microbiology. London, 56: 307 319 .

DATTA, N. e R.W. HEDGES, 1971. Compatibility groups among fi-R factors. Nature. London, 234: 222.

DAVID, M.; M. TRONCHET E J. DENARIE, 1981. Transformation of Azotobacter vinelandii with plasmids RP4 (Inc P-1 group) and RSF 1010 (Inc Q group). Journal of Bacteriology. 
Baltimore, 146: 1154-1157.

DAVIS, L.C.; V.K. SHAH; W.J. BRILL e W.H. ORME-JOHNSON, 1972 , Nitrogenase II. Changes in the EPR signal of component I (iron-molybdenum protein) of Azotobacter vinelandii during repression and derepression. Biochimica et Biophysica Acta. New York, 256: 512-523.

DETROY, R.W.; D.F. WITZ; R.A. PAREJKO e P.W. WILSON, 1968. Reduction of $\mathrm{N}_{2}$ by complementary functioning of two components from nitrogen-fixing bacteria. Proceedings of the National Academy of Sciences. USA, 61: 537-541.

DILWORTH, M.J., 1966. Acetylene reduction by nitrogenfixing preparations from Clostridium pasteurianum. Biochimica et Biophysica Acta. New York, 127: 285-294.

DITTA, G.; S. STANFIELD; D. CORBIN e D. HELSINKI, 1980 . Broad host range DNA cloning system from Gram negative bacteria: Construction of a gene bank of Rhizobium melizoti. Proceedings of the National Academy of Science. Washington, 77: 7347-7351.

DIXON, R.; F.C. CANNON e A. KONDOROSI, 1976. Construction of a $P$ plasmid carrying nitrogen fixation genes from $K$. pneumoniae. Nature. London, 260: 268-271. 
DIXON, R.; C. KENNEDY; A. KONDOROSI; V. KRISHNAPILLAI e M. MERRICK, 1977. Complementation analysis of Klebsielza pneumoniae mutants defective in nitrogen fixation. Molecular and General Genetics. Berlin, 157: 189-198.

DOBEREINER, J., 1966. Azotobacter paspali sp n., uma bactéria fixadora de nitrogênio na rizosfera de Paspalum. Pesquisa Agropecuária Brasileira. Rio de Janeiro, 11: $357-365$

DOBEREINER, J., 1973. Fixation of atmospheric nitrogen in the rhizosphere of tropical gramine. Revista de Microbiologia. São Paulo, 1: 461-481.

DOBEREINER, J., 1977. Potential for nitrogen fixation in tropical legumes and grasses. In: DOBEREINER, J. e.t alii, Eds., Limitations and potentials for biological nitrogen fixation in the tropics. Plenum Press, New York. p. 13-24.

DOBEREINER, J.; J.M. DAY e P.J. DART, 1972. Nitrogenase activity and oxygen sensitivity of the Paspalum notatumAzotobacter paspali association. Journal of General Microbiology. London, 71: 103-116.

DOBEREINER, J.; J.M. DAY e P.J. DART, 1973. Rhizosphere 
associations between grasses and nitrogen fixing bacteria. Effect of $\mathrm{O}_{2}$ on nitrogenase activity in the rhizosphere of Paspalum notatum. Soil Biology Biochemistry. New York, 5: 157-159.

DOMINGO, E.; N. GORDON e R. WARNER, 1972. Azotobacter phages: properties of phage A12, A21, A31, A41 and their constituents DNAs. Virology. New York, 49:439-452.

DROZD, J. e J.R. POSTGATE, 1970. Effect of oxygen on acetylene reduction cytochrome content and respiratory activity of Azotobacter chroococcum. Journal of General Microbiology. London, 63: 63-73.

DROZD, J.; R.S. TUBB e J.R. POSTGATE, 1972. A chemostat study of the effect of fixed nitrogen sources on nitrogen fixation, membranes and free amino-acids in Azotobacter chroococcum. Journal of General Microbiology. London, $73: 221-232$.

DUFF, J.T. e 0. WYSS, 1961. Isolation and characterization of a new series of Azotobacter bacteriophages. Journal of General Microbiology. London, 24: 273-289.

EADY, R.R.; R. ISSACH; C. KENNEDY; J.R. POSTGATE e H.D. RATCLIFFE, 1978. Nitrogenase synthesis in Klebsielza 
pneumoriae: comparison of ammonium and oxygen regulation. Journal of General Microbiology. London, 104: 277285

EADY, R.R. e J.R. POSTGATE, 1974. Nitrogenase. Nature. London, 249: 805-810.

ELMERICH, C., 1984. Azotobacter and Azospirizlim genetics and molecular Biology. In: SUBBA RAO, N.S., Ed., Currents developments in biological nitrogen fixation. Oxford, IBH publishing Co., New Delhi. p. 315-346..

ELMERICH, D.W. e R.H. BURRIS, 1978. Complementary functioning of the component proteins of nitrogenase from several bacteria. Journal of Bacteriology. Baltimore, 134:936-943.

EPHRATI-ELIZUR, E.; P.R. SRINIVASAN e S. ZAMENHOF, 1961. Genetic analysis of means of transformation cf histidine linkage groups in Bacilus subtilis. Proceedings of the National Academy of Science. Washington, $47: 56-63$ 。

ESCHEVERRIGARAY, S.L., 1983. Estabilidade genética e heterose em híbridos interespecíficos de leveduras. Piracicaba, ESALQ/USP, 167 p. (Dissertação de Mestrado). 
ESPIN, G.; A. ALVAREZ-MORALES; F. CANNON; R. DIXON e M. MERRICK, 1982. Cloning of the glnA, ntrB, ntrC genes of Klebsielza pneumoniae and studies of their role in regulation of the nitrogen fixation ( $n i f$ ) gene cluster. Molecular and General Genetics. Ber1in, 186: 518-524.

EVANS, H.J. e L.E. BARBER, 1977. Biological nitrogen fixation for food and fiber production. Science. New York, 197: 332-339.

FISHER, R. e W.J. BRILL, 1969. Mutant of Azotobacter vinelandii unable to fix nitrogen. Biochimica et Biophysicä Acta. New York, 184: 99-105.

FRANCE, C. e C. ELMERICH, 1981. Physiological properties and plasmid content of several strains of Azospirizlum brasizense and A. lipoferum. Annales de microbiologie, Institut Pasteur. Paris, 132A: 3-1. .

FRANCE, C.; C. ROSEMBERG; B. QUIVIGER e C. ELMERICH, 1981 . Plasmid and bacteriophages of Azospirillum. The Society for GeneralMicrobiology Quartely. England, 8:136.

FRANCO, A.A.; J.R.R. PERES e M. NERY, 1978. The use of Azotobacter paspali $\mathrm{N}_{2}$-ase $\left(\mathrm{C}_{2} \mathrm{H}_{2}\right.$ - reduction activity) to measure molybdenum deficiency in soils. Plant and 
Soiz. The Hague, 50: 1-11.

FRIEDMAN, A.M.; S.R. LONG; S.E. BROWN; W.J. BUIKEMA e F.M. AUSUBEL, 1982. Construction of a broad host range cosmid cloning vector and its use in the genetic analysis of Rhizobium mutants. Gene. Amsterdam, 18: $289-296$.

GORDON, J.K. e W.J. BRILL, 1972. Mutants that produce nitrogenase in the presence of ammonia. Proceedings of the National Academy of Sciences. Washington, 69: $3501-3503$

GORDON, J.K. e W.J. BRILL, 1974. Derepression of nitrogenase synthesis in the presence of excess $\mathrm{NH}_{4}^{+}$. Biophysical Research Communications. New York, 59: 967-971.

GORDON, J.K. e R.A. MORE, 1981. Ammonium and methylammonium transport by the nitrogen fixing bacterium Azotobacter vinelandii. Journal of Bacteriology. Baltimore, 148: $435-442$.

GORDON, J.K.; V.K. SHAH e W.J. BRILL, 1981. Feedback inhibition of nitrogenase. Journal of Bacteriology. Baltimore, 148: 884-888. 
GREEN, M.; M. ALEXANDER e P.W. WILSON, 1953. Mutants of the Azotobacter unable to use $\mathrm{N}_{2}$. Journal of Bacterilogy. Baltimore, 66: 623-624.

GROSS, D.C.; A.K. VIDAVER e R.V. KLUCAS, 1979. P1asmids, biological properties and efficacy of nitrogen fixation in Rhizobium japonicum strains indigenous to alkaline soils. Journal of General Microbiology. London, 114: $257-266$.

GUERRY, P.; J. Van EMBDEN e S. FALKOW, 1974. Molecular nature of two nonconjugative plasmids carrying drug resistance genes. Journal of Baeteriology. Baltimore, $117: 619-630$.

HAAKER, H. e C. VEEGER, 1977. Involvement of the cytoplasmic mernbrans in nitrogen fixation by Azotobacter vinelandii. European Journal Biochemistry. Berlin, 77: 1-10.

HAGEMAN, R.V. e R.H. BURRIS, 1978. Nitrogenase and nitrogenase reductase associate and dissociate with each catalytic cycle. Proceedings of the National Academy of Sciences. Washington, 75: 2699-2702.

HAUSINGER, R.P. e J.B. HOWARD, 1980. Comparison of the iron proteins from the nitrogen fixation complexes of 
Azotobacter vinelandii, Clostridium pasteurianum and Klebsiella pneumoniae. Proceedings of the National Academy of Sciences. Washington, 77: 3826-3830.

HELINSKI, D.R., 1977. Plasmids as vector for gene cloning. In: HOLAENDER, A., Ed., Genetic engineering for nitrogen fixation. Plenum Press, New York. p. 19-49.

HIGASHI, S., 1967. Transfer of clover infectivity of Rhizobium trifolii to Rhizobium phaseoli as mediated by an episomic factor. Journal General Applied of Microbiology. Tokio, 13: 391-403.

hill, S.; C. Kennedy; E. KAVAnagh; R. B. GOlberg e R. hanau, 1981. Nitrogen fixation gene ( $n i f L$ ) involved in oxygen regulation of nitrogenase synthesis in Klebsiella pneumoniae. Nature. London, 290: 424-426.

JENSEN, V., 1961. Rhamnose for detection and isolation of Azotobacter vinelandii Lipman. Nature. London, 190: $823-833$.

JOHNSTON, A.W.B.; J.L. BEYNON; A.V. BUCHANAN-WOLLASTON; S. M. SETCHELl; P.R. HIRSCH e J.F. BERINGer, 1978. High frequency transfer of nodulating ability between strains and species of Rhizobium. Nature, London, 276:635-636. 
JOHNSTON, J.H. e M.H. RICHMOND, 1970. The increased rate of loss of penicilinase plasmids from Staphylococcus aureus in the presence of rifampicin. Journal of General Microbiology. London, 60: I37-139.

KADO, C.I. e S.T. LIU, 1981. Rapid procedure for detection and isolation of large and small plasmids. Journal of Bacteriology. Baltimore, 145: 1365-1373.

KARLSSON, J.L. e H.A. BARKER, 1948. Induced biochemical mutants of Azotobacter agizis. Journal of Bacteriology. Ba1timore, 56: 671-677.

KELLY, M., 1969a. Some properties of purified nitrogenase of Azotobacter chroococcum. Biochimica et Biophysica Acta. New York, 171: 9-22.

KELLY, M., 1969b. Comparisons and cross reactions of nitrogenase from Klebsiella pneumoniae, Azotobacter chroococcum and Bacizlus polymyxa. Biochimica et Biophysica Acta. New York, 191: 527-540.

KELly, M.S. e R.H. PRITCHARD, 1965. Unstable 1inkage between genetic markers in transformation. Journal of Bacteriology. Baltimore, 89: 1314-1321. 
KENNEDY, C., 1977. Linkage map of the nitrogen (nif) genes in Klebsiella pneumoniae. Molecular and General Genetics. Berlin, 157: 199-204.

KENNEDY, C . F . CANNON; M. DIXON e J.R. POSTGATE, 1981 . Recent advances in the genetics and regulation of nitrogen fixation. In: , Eds., Current perspectives in nitrogen fixation. Elsevier, p. 146-156.

KENNEDY, C.; R . EADY; E . KONDOROSI e D.K. REKOSH, 1976. The molybdenum-iron protein of Klebsiella pneumoniae nitrogenase. Evidence for nonidentical subunits from peptide mapping. Biochemical Journal. Cambridge, $155: 383-389$.

KENNEDY, C. e R.L. ROBSON, 1983. Activation of nif gene expression in Azotobacter by the nif $A$ gene product of Klebsiella pneumoniae. Nature. London, 301: 626-628.

KNOVICKA, J.; L. POPE e O. WYSS, 1972. Morphology and nucleic acid composition of Azotobacter bacteriophages. Journal of virology. Michigan, 10: 150-152.

KONDOROSI, A.; E. VINCZE; A.W.B. JOHNSTON e J.E. BERINGER, 1980. A comparison of three Rhizobium linkage maps . Molecular and General Genetics. Berlin, 178: 403-408. 
KROL, A.J.M.; J.G.J. HONTELEZ; B. ROOZENDAAL e A. van KAMEN, 1981. On the operon structure of the nitrogenase genes of Rhizobium Zeguminosarum and Azotobacter vinelandii. Nucleic Acids Research. Michigan, 10: 4147-4157.

LAANE, C.; W. KRONE; W. KONINGS; H. HAAKER e C. VEEGER, 1980 . Short term effect of ammonium chroride on nitrogen fixation by Azotobacter vinelandii and by bacteroids of Rhizobium Zeguminosarum. European Journal of Biochemistry. Berlin, 103: 39-46.

LACKS, S. e R.D. HOTCHKISS, 1960. A study of the genetic material determining an enzyme activity in Pneumococcus. Biochimica et Biophysica Acta. New York, 39: 508-518.

LEES, H. e J.R. POSTGATE, 1973. The behavior of Azotobacter chroococcum in oxygen- and phosphate-1imited chemostat culture. Journal of General Microbiology. London, 75 : $161-166$.

LEDERBERG, J. e E.M. LEDERBERG, 1952. Replica plating and indirect selection of bacterial mutants. Journal of Bacteriology. Baltimore, 63: 399-406.

LEMOS, M.V.F., 1980. Estudos genéticos no microrganismo fixador do nitrogênio Azospirizzum brasizense. Ribeirão 
Preto, 70 p. (Tese de Doutoramento).

LEONARD, C.G. e M.J. MATTHEIS, 1965. Different transforming characteristics of colonial variants from auxotrophic mutants of Bacizlus Zicheniformis. Journal of Bacteriology. Baltimore, 90: 558-559.

LUDELL, D.J. e J.B. HOWARD, 1978. Isolation and partial characterization of two different subunits from the molybdenum-iron protein of Azotobacter vineZandii nitrogenase. Journal of Biological Chemistry. New York, $253: 3422-3426$.

MACHADO, V.C. e J. DOBEREINER, 1969. Estudos complementares sobre a fisiologia de Azotobacter paspali e sua dependência da planta (Paspalum notatum). Pesquisa Agropecuária Brasizeira. Rio de Janeiro, 4: 53-58.

MAIER, R.J. e W.J. BRILL, 1976. Ineffective and nonnodulating mutant strains of Rhizobium japonicum. Journal of Bacteriology. Baltimore, 127: 763-769.

MAIER, R.J.; P.E. BISHOP e W.J. BRILL, 1978. Transfer from Rhizobium japonicum to Azotobacter vinelandii of genes required for nodulation. Journal of Bacteriology. Ba1timore, 134: 1199-1201 . 
MANDEL, M. e A. HIGA, 1970. Calcium-dependent bacteriophage DNA infection. Journal of Molecular Biology. New York, $53: 159-162$.

MARCUS, L. e T. KANESHIRO, 1972. Lipid composition of Azotobacter vinelandii in which the internal membrane network is induced or repressed. Biochimica et Biophysica Acta. New York, 288: 296-303.

MAY, J.W.; R.H. HOUGHTON e C.J. PERRET, 1964. The effect of growth at elevated temperatures on some heritable properties of Staphyzococcus aureus. Journal of General Microbiology. London, 37: 157-169.

MAZUR, B.; D. RICE e R. HASELKORN, 1980. Identification of blue green algal nitrogen fixation genes by using heterologous DNA hybridization probes. Proceedings of the National Academy of Sciences. USA, 77: 186-190.

MERRICK, M.J., 1982. A new model for nitrogen control. Nature. London, 267: 362-363.

MEYERS, J.A.; D. SANCHES; L.P. ELWELL e S. FALKON, 1976. A simple agarose electrophoresis method for identification and characterization of plasmid deoxiribonucleic acid. Journal of Bacteriology. Baltimore, 127: 1529-1537. 
MISHRA, A.K. e O. WYSS, 1969. An adenine-requiring mutant of Azotobacter vinelandii blocked in inosinic acid synthesis. Experientia. Basel, 21: 85-88.

MONSOUR, V.; O. WYSS; D.S. KELLOG e D.S. JUNIOR, 1955.

A bacteriophage for Azotobacter. Journal of Bacteriology. Baltimore, $70: 486-487$.

MORTENSON, L.E.; J.A. MORRIS e D.Y. YENG, 1967. Purification, metal composition and properties of molybdo-ferredoxin and azoferredoxin, two of the components of the nitrogenfixing system of Clostridium pasteurianum. Biochimica et Biophysica Acta. New York, 127: 18-25.

MUMFORD, F.E.; J.E. CARNAHAN e J. CASTLE, 1959. Nitrogen fixation of Azotobacter vinelandii. Journal of Bacteriology. Baltimore, $77: 86-90$.

NAGATANI, H.H. e W.J. BRILL, 1974. The effect of Mo, W and $V$ on the synthesis of nitrogenase components in Azotobacter vinelandii. Biochimica et Biophysica Acta. New York, 362: 160-166.

NAGATANI, H.H.; M. SHIMIZU e R.C. VALENTINE, 1971. The mechanism of ammonia assimilation in nitrogen fixing bacteria. Archive of Microbiology. Berlin, 79: 164-175. 
NAGATANI, H.H.; V.K. SHAH e W.J. BRILL, 1974. Activation of inactive nitrogenase by acid treated component $I$. Journal of Bacteriology. Ba1timore, 120: 697-701.

NEIRA, C.A. e J. DOBEREINER, 1977. Nitrogen fixation in grasses. Advances in Agronomy. New York, 29: 1-38.

NESTER, E.W. e J. LEDERBERG, 1961. Linkage of genetic units of Bacizlus subtilis in DNA transformation. Proceedings of the National Academy of Sciences. Washington, $47: 52-55$.

NORRIS, J.R. e D.W. RIBBONS, 1970. Methods in Microbiology. vol. 3A-Academic Press, London. 795 p.

NUTI, M.P.; A.M. LEDEBOER; A.A. LEPIDI e R.A. SCHILPEROORT, 1977. Large plasmids in different Rhizobium species. Journal of General Microbiology. London, 100: 241 248 .

OISHI, M. e S.D. COSLOY, 1974. Specialised transformation in Escherichia coli K12. Nature. London, 248: 112-116.

OPPENHEIM, J. e L. MARCUS, 1970. Correlation of ultrastructure in Azotobacter vinelandii with nitrogen source of growth. Journal of Bacteriology. Baltimore, 101: 286-291. 
OPPENHEIM, J •; R.J. FISHER; P.W. WILSON e L. MARCUS, 1970. Properties of a soluble nitrogenase in Azotobacter. Journal of Bacteriology. Baltimore, 101: 292-296.

PAGE, W.J., 1977. Transformation of Azotobacter vinelandii strains unable to fix nitrogen with Rhizobium spp DNA. Canadian Journal of Microbiology. otawa, 24: 209-214.

PAGE, W.J. e J.L. DORAN, 1981. Recovery of competence in calcium limited Azotobacter vinelandii. Journal of Bacteriology. Baltimore, 146: 33-40.

PAGE, W.J. e H.L. SADOFF, 1976 a. Physiological factors affecting transformation of Azotobacter vinelandii. Journal of Bacteriology. Baltimore, 125: 1080-1087.

PAGE, W.J. e H.L. SADOFF, 1976b. Control of transformation competence in Azotobacter vinelandii by nitrogen catabolite derepression. Journal of Bacteriology. Baltimore, 125: 1088-1095.

PAGE, W.J. e M. von TIGERSTROM, 1978. Induction of transformation competence in Azotobacter vinelandii iron-limited cultures. Canadian Journal of Microbiology. Otawa, 24: 1590-1594. 
PAGE, W.J. e M. von TIGERSTROM, 1979. Optimal conditions for transformation of Azotobacter vinelandii. Journal of Bacteriology. Baltimore, 139: 1058-1061.

PIENKOS, P.T. e W.J. BRILL, 1981. Molybdenum accumulation and storage in Klebsielza pneumoniae and Azotobacter vinelandii. Journal of Bacteriology. Baltimore, 145: $743-751$

PIENKOS, P.T.; S. KLEVICKIS e W.J. BRILL, 1981. In vitro activation of inactive nitrogenase component $I$ with molybdate. Journal of Bacteriology. Baltimore, 145: $248-256$.

POLSINELII, M.; E. BALDANZI; M. BAZZICALUPO e E. GALLORI, 1980. Transfer of plasmid pRDl from Escherichia coir to Azospirizlum brasizense. Molecular and General Genetics. Berlin, 178: 709-711.

POSTGATE, J.R. e KRISHNAPILLAI, V., 1977. Expression of Klebsielza nif and his genes in Salmonelza typhimurium. Journal of General Microbiology. London, 98: 379 385 .

PRAKASH, R.K.; R.A. SCHILPEROORT e M.P. NUTI, 1981. Large plasmids of fast-growing rhizobia: homology studies and 
location of structural nitrogen fixation (nif) genes. Journal of Bacteriology. Baltimore, 145: 1129-1136.

QUINTO, C.; H. de La VEGA; M. FLORES; L. FERNANDEZ; T. BALLADO; G. SOBERON e R. PALACIOS, 1982. Nitrogen fixation genes are reiterated in Rhizobium phaseoli. Nature. London, 299: 724-726.

QUISPEL, A., 1974. Introduction general. In: , Ed.,

The biology of nitrogen fixation. North-Holland Publ. Co., Amsterdam. p. 1-8.

RICE, D.G.; B.J. MAZUR e R. HASELKORN, 1982. Isolation and physical mapping of nitrogen fixation genes from the cyanobacterium Anabaena 7120. Journal of Biological Chemistry. New York, 257: 13157-13163.

RICKENBERG, H.V., 1974. Cyclic-AMP in prokariotes. Annual Review Microbiology. Palo Alto, 28: 353-369.

RIVERA-ORTIZ, M. e R.H. BURRIS, 1975. Interactions among substrates and inhibitors of nitrogenase. Journal of Bacteriology. Baltimore, 123: 537-545.

ROBSON, R.L., 1979. Characterization of an oxygen stable nitrogenase complex isolated from Azotobacter chroococcum. 
Biochemical Journal. Cambridge, 181: 569-575.

ROBSON, R.L., 1981. Detection and function of indigenous plasmids of Azotobacter. The Society for General Microbiology Quarterly. England, 8: 136-137.

ROBSON, R.L. e J.R. POSTGATE, 1980. Oxygen and hydrogen in biological nitrogen fixation. Annual Review Microbiology. Palo Alto, 34: 183-207.

ROBERTS, G.P. e W.J. BRILL, 1981. Genetics and regulation of nitrogen fixation. Annual Review Microbiology. Pa1o A1to, 35: 207-235.

ROBERTS, G.P.; T. MAC NEIL; D. MAC NEIL e W.J. BRILL, 1978. Regulation and characterization of protein products coded by the nif (nitrogen fixation) genes of Klebsielza pneumoniae. Journal of Bacteriology. Baltimore, 136: $267-279$.

ROSENBERG, C.; P. BOISTARD; J. DENARIE e F. CASSE-DELBARD, 1981. Genes controlling early and late functions in symbiosis are located on a megaplasmid in Rhizobium meliloti. Molecular and General Genetics. Berlin, 184: $326-333$. 
RUBIN, S.T. e E.D. ROSENBLUM, 1975. Effects of ethidium bromide on growthand on loss of the penicillinase plasmid of Staphylococcus aureus. Journal of Bacteriology. Baltimore, 108: 1200-1204.

RUVKUN, G.B. e F.M. AUSUBEL, 1980. Interspecies homology of nitrogenase genes. Proceedings of the National Academy of Sciences. Washington, 77: 191-195.

SADOFF, H.L.; E. BERKE e B. LOPERFIDO, 1971. Physiological studies of encystment in Azotobacter vinelandii. Journal of Bacteriology. Baltimore, 105: 185-189.

SADOFF, H:L.; B. SHIMEI e S. ELLIS, 1979. Characterization of Azotobacter vinelandii deoxyribonucleic acid and folded chromosomes. Journal of Bacteriology. Baltimore, $138: 871-877$.

SAITO, S.M.T., 1978. Relações entre fixação de ${ }^{15} \mathrm{~N}_{2}$, evolução de $\mathrm{H}_{2}$ e redução de $\mathrm{C}_{2} \mathrm{H}_{2}$ em feijoeiro (Phaseolus vulgaris, L.). Piracicaba, ESALQ/USP, 97 p. (Tese de Doutoramento).

SANTOS, D.S. M.H.T. AFFONSO, 1982. 10 Curso avançado sobre biologia molecular de plasmidios bacterianos-guia de trabalhos práticos. Escola Paulista de Medicina. 
SCHENK, S.P.; C.F. EARHART e O. WYSS, 1977. A unique envelope protein in Azotobacter vinelandii. Biochemical and Biophysical Research Communications. New York, 77: $1452-1458$.

SEN, M. e S.P. SEN, 1965. Interspecific transformation in Azotobacter. Journal of General Microbiology. London, $41: 1-6$.

SHAH, V.K. e W.J. BRILL, 1973. Nitrogenase IV. Simple method of purification to homogeneity of nitrogenase components from Azotobacter vinelandii. Biochimica et Biophysica Acta. New York, 305: 445-454.

SHAH, V.K. e W.J. BRILL, 1977. Isolation of an ironmolybdenum cofactor from nitrogenase. Proceedings of the National Academy of Sciences. USA, 74: 3249-3253.

SHAH, V.K.; L.C. DAVIS e W.J. BRILL, 1972. Nitrogenase I. Repression and derepression of the iron-molybdenum and iron proteins of nitrogenase in Azotobacter vinelandii. Biochimica et Biophysica Acta. New York, 256: 498-511.

SHAH, V.K.; L.C. DAVIS; J.K. GORDON; W.H. ORME-JOHNSON e W. J. BRILL, 1973. Nitrogenase III. Nitrogenaseless mutants of Azotobacter vinelandii: activities cross- 
reactions and EPR spectra. Biochimica et Biophysica Acta. New York, 292: 246-255.

SHAH, V.K.; L.C. DAVIS; M. STIEGHORST e W.J. BRILL, 1974 . Mutant of Azotobacter vinelandii that hyperproduces nitrogenase component II. Journal of Bacteriology. Baltimore, 117: 917-919.

SHANMUGAM, K.T. e C. MORANDI, 1976. Amino acids as repressors of nitrogenase biosynthesis in Klebsiella pneumoniae. Biochimica et Biophysica Acta. New York, 437: 322-3.32.

SHERINGS, G.; H. HAAKER e L. VEEGER, 1977. Regulation of nitrogen fixation by Fe-S protein II in Azotobacter vinelandii. European Journal of Biochemistry. Berlin, 77: $621-630$.

SIBOLD, L., 1982. The polar effect on nif $M$ of mutations in the nif $V, S, V$ genes of Klebsiella pneumoniae depends on their plasmid or chromosomal location. Molecular and General Genetics. Beriin, 186: 569-571.

SMITH, B.E.; R.N.F. THORNELEY; R.R. EADY e L.E. MORTENSON, 1976. Nitrogenases from Klebsiella pneumoniae and Clostridium pasteurianum. Kinetic investigations of cross-reactions as a probe of the enzyme mechanism. 
The Biochemical Journal. 'Cambridge, 157: 439-447.

SOCOLOFSKY, M.D. e 0. WYSS, 1961. Cysts of Azotobacter. Journal of Bacteriology. Baltimore, 81: 946-954.

SOCOLOFSKY, M.E. e O. WYSS, 1962. Resistance of the Azotobacter cyst. Journal of Bacteriology. Baltimore, $84: 119-124$.

SONSTEIN, S.A. e J.N. BALDWIN, 1972. Nature of the elimination of the penicillinase plasmid from Staphylococcus aureus by surface-active agents. Journal of Bacteriology. Baltimore, 111: 152-155

SORGER, G.J., 1968. Regulation of nitrogen fixation in Azotobacter vinelandii $O P$ and in an apparent $1 \mathrm{y}$ partially constitutive mutant. Journal of Bacteriology. Baltimore, 95: 1721-1726.

SORGER, G.J. e D. TROFIMENKOFF, 1970. Nitrogenaseless mutants of Azotobacter vinelandii. Proceedings of the National Academy of Sciences. Washington, 65: 74-80.

SPRENT, J.I., 1979. The range of nitrogen fixing organisms. In: , Ed., The biology of nitrogen-fixing organisms. McGraw-Hil1 Ltda. p. 1-45. 
STRANDBERG, G.W. e P.W. WILSON, 1967. Molecular H and the $\mathrm{N}_{2}$ function of Azotobacter. Proceedings of the National Academy of Sciences. Washington, 58: 1404-1409.

STRANDBERG, G.W. e P.W. WILSON, 1968. Formation of the nitrogen fixing enzyme system in Azotobacter vinelandii. Canadian Journal of Microbiology. otawa, 14: 25-31.

St. JOHN,R.T. e W.J. BRILL, 1972. Inhibitory effect of methylalanine on glucose grown Azotobacter vinelandii. Biochimica et Biophysica Acta. New York, 261: 63-69.

STREICHER, S.L.; E.G. GURNEY e R.C. VALENTINE, 1972. The nitrogen fixation genes. Nature. London, 239:495-499.

STREICHER, S.L.; K.T. SHANMUGAM; F . AUSUBEL; C. MORANDI. e R.B. GOLDBERG, 1979. Regulation of nitrogen fixation in Klebsiel.la pneumoniae: evidence for a role of glutamine synthetase as regulator of nitrogenase synthesis. Journal of Bacteriology. 'Baltimore, 120: 815-821.

STUMBO, C.R. e P.L. GAINEY, 1938. An apparent induced los of nitrogen-fixing ability in Azotobacter. Journal of Agricultural Research. Washington, 57: 217-227.

SUNDARESAN, V.; J.D.G. JONES; D.W. OW e F.M. AUSUBEL, 
Klebsiella pneumoniae nif $A$ product activates the Rhizobium meliloti nitrogenase promoter. Nature. London, 301: 728-732.

SWISHER, R.H.; M.L. LANDT e F.J. REITHEL, 1977. The molecular weight of and evidence for two types of subunits in the molybdenum-iron-protein of Azotobacter vinelandii nitrogenase. Biochemical Journal. Cambridge, $163: 427-433$.

TANAKA, M.; M. HANIU; K. YASUNOBU e L.E. MORTENSON, 1977 . The amino acid sequence of Clostridium pasteurianum iron protein, a component of nitrogenase I. Tryptic peptides. Journal Biologycal Chemistry. New York, 252: $7081-7088$.

TANAKA, M.; M. HANIU; K.T. YASUNOBU e L.E. MORTENSON, 1977 b. The amino acid sequence of Clostridium pasteurianum iron protein, a component of nitrogenase III. The $\mathrm{NH}_{2}-$ terminal and $\mathrm{COOH}$ - terminal sequences, tryptic peptides of large cyanogen bromide peptides and the complete sequences. Journal Biological Chemistry. New York, $252: 7093-7100$.

TERZAGHI, B.E., 1980a. U1traviolet sensitivity and mutagenenesis of Azotobacter. Journal of General 
Microbiology. Iondon, 118: 271-273.

TERZAGHI, B.E., 1980b. A method for the isolation of Azotobacter mutants derepressed for nif. Journal of General Microbiology. London, 118: 275-278.

THOMPSON, B.J.; E. DOMINGO e R.C. WARNER, 1980 .

Pseudolysogeny of Azotobacter phages. Virology. New York, 102: 267-277.

THOMPSON, B.J.; M.S. WAGNER; E. DOMINGO e R.C. WARNER, 1980 . Pseudolysogeny conversion of Azotobacter vinelandii by phage A21 and the formation of a stably converted form. Virology. New York, 102: 278-285.

THOMPSON, B.J.; E. DOMINGO e R. WARNER, 1973. Properties of Azotobacter phage.A14 and its DNA. Virology. New York, 56.: 523-531.

THORNELEY, R.N.F.; R.R. EADY e M.G. YATES, 1975. Nitrogenases of Klebsiella pneumoniae and Azotobacter chroococcum: complex formation between the component proteins. Biochimica et Biophysica Acta. New York, 403: 269-284.

TSAI, L.B. e L.E. MORTENSON, 1978. Interaction of the nitrogenase components of Anabaena cylindrica with those 
of Clostridium pasteurianum. Biochemical and Biophysical Research Communications. New York, 81: 280-285.

TSHITENGE, G.; N. LUYINDULA; P.F. LURQUIN e L. LEDOUX, 1975. Plasmid DNA in Rhizobium vigna e R. trifolii. Biochimica et Biophysica Acta. New York, 414: 357-361.

VOLPON, A.G.T.; H. De-POLLI e J. DOBEREINER, 1981. Physiology of nitrogen fixation in Azospirizlum lipoferum Br 17 (ATCC29709). Archive of Microbiology. Berlin, $128: 371-375$.

WACKERNAGEL, W., 1973. Genetic transformation in Escherichia coli: the inhibitory role of the rec BC DNAse. Biochemical and Biophysical Research Communications. New York, 51: 306-311.

WEIR, K.L., 1980. Nitrogen fixation association with grasses. Tropical Grassland. Brisbaine, 14(3): 194-201.

WISE, F.M.; S.P. ALEXANDER e M. POWERS, 1973. Adenosine $3^{\prime}-5^{\prime}-c y c 1 i c$ monophosphate as a regulator of bacterial transformation. Proceedings of the National Academy of Sciences. Washington, $70: 471-474$.

WYSS, 0. e B.M. WYSS, 1950. Mutants of Azotobacter that 
do not fix nitrogen. Journal of Bacteriology. Baltimore, 5s: 287-291.

YATES, M.G., 1970. Control of respiration and nitrogen fixation by oxygen and adenine nucleotides in $\mathrm{N}_{2}$ grown Azotobacter chroococcum. Journal of General Microbiology. London, 60: 393-401.

YATES, M.G. e C.W. JONES, 1974. Respiration and nitrogen fixation in Azotobacter. Advances in Microbial Physiology. Academic Press, London, 11: 97-135.

YOUNG, F.E. e J. SPIZIZEN, 1963. Incorporation of deoxyribonucleic acid in the Bacilzus subtilis transformation system. Journal of Bacteriology. Baltimore, 86: 392-400.

ZURKOWSKI, W., 1981. Conjugational transfer of the nodulation-conferring plasmid pWZ2 in Rhizobium trifolii. Molecular and General Genetics. Berlin, 181: 522-524.

ZURKOWSKI, W., 1982. Molecular mechanism for loss of nodulation properties of $R$. trifolii. Journal of Bacteriology. Baltimore, 150: 999-1007.

ZURKOWSKI, W. e Z. LORKIEWICZ, 1979. Plasmid-mediated control of nodulation in Rhizobium trifolii. Archive of Microbiology. Ber1in, 123: 195-201. 